V.I. VERNADSKY TAURIDA NATIONAL UNIVERSITY

\title{
SOCIAL AND PSYCHOLOGICAL PROBLEMS OF MODERN SOCIETY
}

Collective monograph

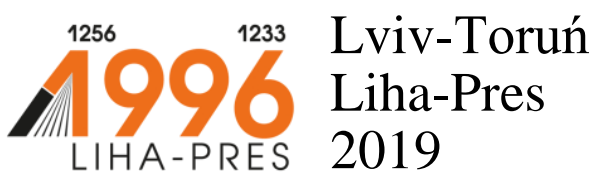




\section{Reviewers:}

Konrad Janowski, PhD, Vice-dean of the Faculty of Psychology, University of Economics and Human Sciences in Warsaw (Republic of Poland);

Prof. dr hab. Tadeusz Dmochowski, University of Gdansk (Republic of Poland).

Social and psychological problems of modern society : collective monograph / S. P. Bielavin, T. I. Bielavina, I. N. Bila, V. Ye. Vynohradova, etc. - Lviv-Toruń : Liha-Pres, 2019. - $184 \mathrm{~s}$.

ISBN 978-966-397-109-4

Liha-Pres is an international publishing house which belongs to the category "C" according to the classification of Research School for Socio-Economic and Natural Sciences of the Environment (SENSE) [isn: 3943, 1705, 1704, 1703, 1702, 1701; prefixMetCode: 978966397]. Official website - www.sense.nl.

The monograph presents the results of theoretical-empirical research, which reveals the socio-psychological problems inherent in modern society.

In particular, the theoretical analysis of the development of creativity and abilities of the individual at different levels and determinants of the role of society in this process.

The socio-psychological factors of personality growth in a family are defined in the monograph. The theoretical and methodological problems of the study of gender-role identification of adolescents have been determined. The results of an empirical study of young students' views on the issue of gender discrimination are presented.

The subject of the presented works covers a wide range of issues, knowledge of these papers helps to determine the trends of modern society in the context of socio-psychological perspectives. 


\section{CONTENTS}

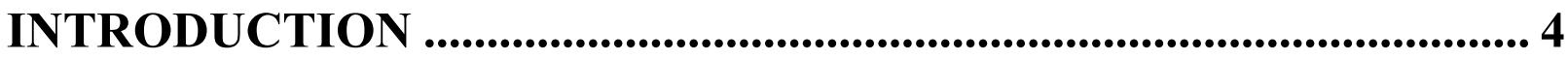

THE SPECIAL ASPECTS OF COMMUNICATIVE

INTERACTION OF YOUNG STUDENTS

IN POLYETHNIC SPACE OF MODERN UKRAINE

Bielavin S. P. 5

THE LEGAL SELF-DETERMINATION

OF THE IMPOVERISHED SOCIAL GROUPS'

REPRESENTATIVES

Bielavina T. I.

SOCIO-PSYCHOLOGICAL FACTORS

OF PERSONAL GROWTH IN FAMILY CONDITIONS

Bila I. N

SOCIO-PSYCHOLOGICAL ASPECTS OF DEVELOPMENT

OF PERSONALITY DEMOCRACIES IN MODERN UKRAINE

Vynohradova V. Ye.

GENDER DISCRIMINATION: VIEW OF STUDENT YOUTH

Kostina T. O.

RECREATIONAL APPROACH TO REALIZATION

OF SOCIAL WORK PRINCIPLES

Kostyuchenko O. V.

THE CHILD NEGLECT

AS A SOCIO-PSYCHOLOGICAL PROBLEM

Mitina S. V.

THE THEORETICAL-METHODOLOGICAL PROBLEMS

OF GENDER-ROLE IDENTITY OF ADOLESCENTS

Osmanova A. M.

CONCLUSIONS 


\section{INTRODUCTION}

The multi-authored monograph is devoted to theoretical and practical ground and complex research problems of modern society as a sociopsychological foundation of the interaction between science and society.

The importance of social and psychological problems is determined by the logic of the development of modern society and the necessity to integrate the results of general psychological, social and psychological, sociological research. These results are aimed at a comprehensive analysis of operating conditions and factors of the development of various social processes.

This monograph is the results of the scientific research of the scientists of the Department of Psychology and Pedagogy of the V. I. Vernadsky Taurida National University. The results of theoretical and experimental studies of various socio and psychological aspects of modern society are presented.

The psychological and social approach allows studying the personality in a very specific social context. The subject of the study may be the recreational approach to the principles of social work, gender identity of adolescents, self-identity of the short-life social groups, communication interactions of young students, personality development skills, left unchecked children, gender discrimination, identity formation in a family, etc.

The authors of the monograph hope that the results of the presented research will be interesting and useful to scholars and experts who are interested in the socio and psychological problems of modern society. The content of the monograph will be useful for students of psychological specialties, teachers, and parents who bring up children of all ages.

The authors thank the leadership of the V. I. Vernadsky Taurida National University, including the Director of Academic and Research Institute of Humanities, Ph.D., Associate Professor Olexander Ilyashko for the idea of writing this monograph and contribution of its publishing. 


\section{THE SPECIAL ASPECTS OF COMMUNICATIVE INTERACTION OF YOUNG STUDENTS IN POLYETHNIC SPACE OF MODERN UKRAINE}

\section{Bielavin S. P.}

\section{INTRODUCTION}

The modern socio-psychological and ethnopolitical reality is characterized by the growth of interethnic contacts. Intercultural interaction and communication go along with a break social stereotypes and changing of value content.

This is due to the attention of scientists for the socio-psychological problems of intergroup, intercultural cooperation and ethnic tolerance in the multicultural space ${ }^{1,2}$. In particular, the issue is coexistence and interplay of the ethnic communities especially modern Ukraine which is an important condition for the functioning of a society involving a subject.

The transition stage as a special state of society has a prolonged, unstable and strong character that is forming a long-term approach to life. The aggravation of the social contradictions is determined by the differentiation of society based on reference, discretization of social relations, and strengthening ethnic and language intolerance.

Social instability highlights the need for social relationships solidarity, identity, and group affiliation. The spread of the phenomena founded in this study such as the intensification of practicalism and individualism among young people are pointed out as well by other researchers who study the youth socialization.

E.I. Holovakha considers the demonstration of social intolerance that is growing in society recently is sociopathy. It is shown a wherever deterioration of living conditions is. Therefore instead of finding ways to solve such a state, guilty and social enemies are looking for.

The public opinion polls in the first years of the reformation period showed intolerant towards party functionaries and civil servants of the majority of respondents. the intolerance was becoming blurred, spreading

\footnotetext{
${ }^{1}$ Лебедева Н.М. Этническая толерантность в поликультурных регионах России / Н.М. Лебедева. - М.: Институт этнологии и антропологии РАН. - 2002. - 296 с.

${ }^{2}$ Платонов Ю.П. Основы этничной психологии / Ю.П. Платонов. - СПб.: Речь, 2003. - 452 с.
} 
to representatives of various social groups and becoming more aggressive due to the growth of social, economic, and political difficulties.

E.I. Holovakha considers sociopathy as a social pathology that leads to an indefinite and unstable system of norms, values, and mass offenses of social adaptation. The researcher remarks intolerance is a culture of confrontation, and the consensus is a culture of compromise, tolerance, and the ability to "betray one's principles" for the sake of the interests of the society ${ }^{3}$.

At the same time, the growth of inter-ethnic tension contributes to the demonstration of the most characteristic features of the people, immanent in the past, adaptive ways of people's behavior which became entrenched as the most successful.

The ideas of them form an important part of the ethnic identity, interact with the educational formations, and form a conative (behavioral) structures of ethnicity that develop the ways of intragroup organization and its mobilization.

\section{Theoretical approaches to study of communicative interaction of young students in polyethnic space}

According to the humanistic concept, human nature in most contemporary views is understood as the formation. Nothing is guaranteed to a person in this process and this formation is complex substantially or even ambivalent. The transformation of the idea of a human being can be explicated through the opinion of G. Jonas ${ }^{4}$ about the impossibility of "neglecting the ambivalence" as it is, otherwise it would fundamentally exclude the possibility of a person's side to reveal his/her incomprehensible desire for freedom. The representatives of "New existentialists", e.g. M. Polany ${ }^{5}$, believe not the isolation of the individual from the "other" makes his being "authentic" but on the contrary, only in actions with "other" s/he can only be like that.

The scientific discourse within the problem is considered from the ethno-cultural approach also widely. The term "ethnos" is used in broad and narrower meanings. In the first i.e. the broad meaning, the "ethnos" (or ethnic

\footnotetext{
Головаха Е.И. Социальные патологии посткоммунистического общества / Е. И. Головаха // Политическая мысль. - 1994. - № 4. - С. 36-45.

${ }^{4}$ Йонас Г. Принцип відповідальності. У пошуках етики для технологічної цивілізації / пер. 3 нім. - К. : Лібра, 2001. - 400 с. - Друк. за виданням : Jonas Hans. Das Prinzip Verantwortung. - Frankfurt am Main, 1979.

${ }^{5}$ Полани М. Личностное знание. На пути к посткритической философии / М. Полани. - М. : Прогресс, 1985. $-344 \mathrm{c}$.
} 
group) is defined as a group of people that has developed historically, and is connected with the community of territory where it was formed, the common language, culture, and the peculiarities of its mental composition.

According to O.M. Lozova, all items, demonstrations and processes of culture are acts of communication on the merits because the "reflected consciousness of world outlook" $" 6$ is transmitted through the communication. Ethnic consciousness is defined as one of the forms of the attitude of a certain ethnic group to other groups. O.M. Lozova considers ethnic consciousness to produce an ethnic image of the world ${ }^{7,8}$.

The ethnic stereotypes are an important component of social consciousness. They are the cognitive core of the ethnic identity, its content in the structure of the ethnic image, or the ethnic stereotype. The ethnic orientational education (stereotypes, bias, superstition), values, value orientations, and psychological universals are distinguished. When interethnic tension appears these phenomena are especially manifest and characterize the properties of the ethnic community as the most successful adaptive behaviors. By V.S. Ageeva's definition, they differ in brightness, relief, expressiveness, representativeness in the social and individual consciousness, practical acuteness and urgency'.

According to S.A. Kolosov, a social stereotype is considered an emotionally rich, stable, and value-definable image that is maximally standardized. The psychological phenomena of generalization, generalization, categorization, schematization of information obtained inexperience are the basis for its appearance. Social stereotypes as a controller of social relations are inherent in the polarization of the characteristics of the subject and object, and the rough fixation of such a polar dichotomy ${ }^{10}$.

However, in any meaning, the ethnos is a stable group and exists as a stable system that opposes to everything else based on the distinction

6 Лозова О.М. Мова в етнічній картині світу / Лозова О.М. // Вісник Київського міжнародного університету. Збірник наукових статей. - Серія: Психологічні науки.- Вип. 13. - К.: КиМУ, 2009. C. $110-123$.

7 Лозовая О.Н. Психология этнического сознания в Украине: история, настоящее, перспективы / Лозовая О.Н. // Историческая психология: истоки и современное состояние : Монография / под науч. ред. И.Н. Коваля, В.И. Подшивалкиной, О.В. Яремчук. - Одесса: Одесский национальный університет им. И.И. Мечникова, 2012. - С. 115-129.

8 Лозовая О.Н. Психология этнического сознания в Украине: история, настоящее, перспективы / Лозовая О.Н. // Историческая психология: истоки и современное состояние : Монография / под науч. ред. И.Н. Коваля, В.И. Подшивалкиной, О.В. Яремчук. - Одесса: Одесский национальный університет им. И. И. Мечникова, 2012. - С. 115-129.

9 Агеев В.С. Межгруповое взаимодействие. Социально-психологические проблемы / В.С. Агеев. М. : МГУ, 1990. - 240 с.

io Колосов С.А. Манипулятивные стратегии дискурса ненависти / С.А. Колосов // Критика и семиотика. - Вып. 7. - Новосибирск, 2004. - С. 248-256. 
between "we are" - "not we are" ("they are"), "own - stranger", "better worse", etc. This recognition of the ethnic group of its unity is the main criterion of the ethnic group and reflects its existing integrity as a system in the minds of people. However, ethnicity is the result not only consciousness but also the humanity and the reflection of a particular physical or biological reality. According to H.S. Lozko, a person's awareness of his/her belonging to a certain ethnic community, the identification of his/her I am with us, the distinction we are with respect to their and other communities have a special place among subjective features of nation and a national consciousness that can be conventionally called as a result of the self-knowledge of the representatives of nation ${ }^{11}$.

O. Vasilchenko also writes about the role of ethno-social representations reflecting a set of views, thoughts, convictions, beliefs, ideas presented in everyday thinking as well as legends, myths, proverbs, and fairy tales. He believes that Ethnic identity as a rational-cognitive act is aware of itself as a member of the ethnic community, awareness of its place among ethnic groups, its position in the system of interethnic relations. The formation of a harmonized system of group ethnic conceptions (as elements of which we allocate certain ethnic images with their inherent values, stereotypes, prejudices, and superstitions) is the result of the rational-cognitive identification. General knowledge unites the group members and is the basis for distancing from other groups"12.

Scientists define some different positions on this issue but there are some generally acceptable ethnic identity characteristics for most authors. This is based on the following: ethnonocultural features (customs, rituals, national traits of everyday life); antropopsychological type; common origin; the unity of the territory, the area that can be mobile or permanent; mutual purposes; a state; a language; national behavior which is determined by the national character and is based on traditional custom; confessional features; an axiological sign that means an ethnic system of values; the most important feature is determined by the identity of the ethnic group, "the soul of the ethnic group"".

A contemporary social psychologist P.P. Hornostay presents the phenomenon of "We are" as a symbolic group role when the individual

11 Лозко Г.С. Етнологія України: філософсько-теоретичний та етнорелігієзнавчий аспект: навч. посіб. / Г. Лозко. - К. : АртЕК, 2001. - 304 с.

12 Васильченко О. Уявлення молодих українців про українців / Ольга Васильченко // Соціальна психологія. - 2003. - № 1. - С. 123-133.

13 Помиткін Е.О. Психологічні механізми духовного розвитку сучасного професіонала / Е. Помиткін // Соціальна психологія. - 2010. - № 4. - С. 47-54. 
consciousness is superseded by different forms of group consciousness that means a person is depersonalized ${ }^{14}$.

M.M. Slyusarevsky notes that "the human we are" is more ancient than "I am". Therefore, the individual psyche still cannot always resist societal, the latter is often stronger than an individual. The individual consciousness depends on the generational extraneous features of mass consciousness which function within this consciousness. The person is influenced by the quantified commons of the worldview, concentrated in the so-called social stereotypes"15.

I.V. Danylyuk considers the creation of an image of the group "We are" can be determined as an appearance of stereotypes of internal and external enemies ${ }^{16}$.

A famous social psychologist P. M. Shikhiriev considers that the perspectives of social psychology are connected with studies about the interaction of an individual and society as a united organism and should be conducted at the level of reality which is specified by universal values. $\mathrm{He}$ conceives the social interaction as a link between social actors (an individual and a collective) which is implemented psychologically concerning one another and to reality. P.M. Shikhiriev notes that the social signs of interaction start in the process of exchange the system of subjectsubjective and subject-objective interactions and the attitude to them. $\mathrm{He}$ emphasizes that the processes of appearance, functioning, and extinction of forms of objectification and value attitude in social exchange in real life should be studied ${ }^{17}$.

O.M. Vasilchenko notes that the object of the person's interaction, group, and society as a united organism is the image of that is defined as a form of "the existence of value attitude, objectified experience, and material that is used for the creation of the group and social ideology. Indeed, the identity is a valuable experience of its uniqueness that is given as the "I am" or "we are" images"18.

\footnotetext{
${ }^{14}$ Горностай П.П. Психологічний феномен «Ми» / П.П. Горностай // Соціальна психологія. - 2006. № 2.; - С. 88-96.

${ }^{15}$ Слюсаревський М.М. «Ми» і «Я» в сучасному світі: Вибрані твори / М.М. Слюсаревський. - К. : Міленіум, 2009. - 340 с. - С. 113-120.

16 Данилюк І.В. Мова як чинник згуртованості групового «Ми» / I.В. Данилюк // Соціальна психологія. - 2008. - № 3. - С. 105-112.

17 Шихирев П.Н. Современная социальная психология / П.Н. Шихирев. - М. : ИП РАН, КСП+, Академический Проект, 1999. - 447 с.

${ }_{18}^{8}$ Васильченко О.М. Методи психосемантики в дослідженні соціальних уявлень / Ольга Васильченко // Соціальна психологія. - 2004. - № 2 (4). - С. 19-37.
} 
A crucial role in researching this problem was performed by the works of B.F. Porshnev who was studying the group phenomenon "we are - they are". He pointed to the primacy of the appearance "they are" image because through the realization of this notion ("they are" - "not like us") the community can perceive itself as it is ${ }^{19}$.

B.F. Porshnev argued that the evolution of the group phenomenon "we are" has deep historical roots. "How genetically ancient is this experience one can judge the child's psyche which has a very clear distinction of all "strangers" and this is very casual without distinguishing between strangers who are dangerous and safe, etc. However, a very strong psychic mechanism is immediately turned on that is a complex of specific reactions occurs when a "stranger" is trying to contact including cry and roar - a call to "theirs" 20 .

He also gave a careful analysis of the socio-psychological phenomena of the formation of the subjective and group "we are" but emphasized the primacy of the rise of the phenomenon "they are" ("alien") which became an outstanding social fact precisely for the development of the individual's sociality. According to the author, speaking about the socio-psychological content of the selected categories that in the primacy society "we are" are always "people" literally that is people in general meaning while "they are" are not quite people. The name of many tribes and peoples in translation simply means "people". This illustrates once again that in the psychological meaning "we are" is a very difficult psychological category ${ }^{21}$.

A lot of socio-psychological studies are devoted to the problem of communication. It is traditionally regarded as a semantic aspect of social interaction, mutual influence of cultural units, the exchange of different ideas, interests, feelings, and mood. Within the framework of proposed work, the so-called interethnic communication deserves special attention as a system of social and psychological phenomena and processes that appear as a result of internal connections, direct interaction, and communication of different nationalities ${ }^{22,23}$.

\footnotetext{
19 Поршнев Б.Ф. Противопоставление как компонент этнического самосознания / Б.Ф. Поршнев. М. : Наука, 1973. - 346 с.- C. 163-184.

${ }^{20}$ Поршнев Б.Ф. О начале человеческой истории: (Проблемы палеопсихологии) / Б.Ф. Поршнев. - М. : Мысль, 1974. - 488 с.

21 Поршнев Б.Ф. Социальная психология и история / Б.Ф. Поршнев. М. : Наука, 1979. C. 73-126. С. 84-96. $452 \mathrm{c}$

Платонов Ю.П. Основы этничной психологии / Ю.П. Платонов. - СПб.: Речь, 2003. -

Крысько В.Г. Социальная психология: словарь - справочник / В.Г. Крысько. - Мн.: Харвест, М.: ACT, 2001. - 668 c. $(175-177)$.
} 
We have selected certain methods and diagnostic techniques for revealing the basic characteristics of ethnic identity and the characteristics of the communicative profile of youth understanding the communicative interaction in the polyethnic space in this way.

Social and ethnic empathy acts as a perceptual mechanism as an emotional response of one person to the experience of another and as a positive attitude to another. A system of values is formed in the process of empathic interaction that determines behavior concerning others. It is based on the mechanism of conscious or unconscious identification that is a result of comparing oneself with others. Ethnical empathy acts as a psychological mechanism for the preservation of the ethnic group, national culture, and national consciousness. Ethnic empathy is actualized in a situation of ethnic diversity in which people seek unconsciously of one's kind of guides, traditions, and habits; this is close to such indicators as "affiliation" and affiliation motivation of interaction. Emotional sensitivity to the experiences of others relates to the highest moral feelings. The low levels of empathy or controversial facts may suggest that social infantilism presents.

"The method of diagnosis of social empathy", "The methodology of diagnostics of the level of polyconymic empathy", "The method of diagnosis of affiliation motives", "The methodology of diagnostics of selfassessment of approval motivation", "The method of diagnostics of motivational orientations in interpersonal communication" was used in the study to determine the level of empathy, and the need for approval.

The next characteristic determines the peculiarities of acceptance of others which is characterized by either high tolerance to the others and the ability to accept "differentness" or a certain level of partiality and the tendency to treat another individual or a certain group differently than to the others. This may bring about ethnic, cultural, and gender bias. The prejudice can be as positive if someone treats the object of bias kindly as negatively if someone expresses dislike about him/her. "The method of diagnosis of the adoption of others" is used in the study to establish the level of acceptance or bias.

The level of personal installation "altruism - selfishness" indicates the orientation of a humanistic view of life. It can be directed to unselfish care of others and neglecting one's interests on the one hand or it can be directed to the on indifference, listlessness to others, and to meet their own 
needs at the expense of others on the other hand. As a rule, altruism is either deterministic or correlated with empathy: helping to closed people they contribute to preserving the integrity of the community, the genofond, etc. To study the socio-psychological guideline "altruism - selfishness" of a personality in this paper "The methodology of diagnosis of personal installation "altruism - selfishness" was used.

A socio-psychological activity of the individual which allows determining the main needs as the motivators of an individual is an important characteristic for our study. The socio-psychological activity can act as the proactive influence of a person or society, community, and ethnos on the environment, other people and themselves changing the conditions of their vital activity and developing the organizational structure and psyche. It can also be multidirectional either beneficial and progressive or harmful to other people. To establish the authorities' predominant needs, achieve success, tendencies to affiliation as requirements for the acceptance of the group and respect "The methodology of diagnosing the motivators of social and psychological activity of an individual" is used.

The person's requirement for communication, emotional contacts and the tendency of a person to look for such a person especially showed in frustration situations.

The necessity of a person to communicate and have emotional contacts, the tendency of a person to look for his/her kind is showed particularly in frustration situations. If there is no opportunity for communication people who are prone to affiliation feel anxiety and suffering. In this meaning, affiliation can be as a motivational variable demonstrating the difference in the propensity to human interaction and communication.

Aggression has been studied thoroughly by Y.M. Antonyan and V.V. Guldan in 1991, etc. The results of these studies can be summed up as follows: 1) aggression is not an inevitable reaction to frustration situations, since a person may be taught non-aggressive behavior as s/he learns aggression in the same manner; 2) the behavior of a person is influenced by the significance of frustration situation; this affects how intensely s/he responds to $\mathrm{it}^{24}$.

The protective mechanisms are another widespread group of ways responding to frustration situations. The theory of protective mechanisms

\footnotetext{
${ }^{24}$ Антонян Ю.М. Криминальная патопсихология / Ю.М. Антонян, В.В. Гульдан. - М. : Наука, 1991. C. $129-139$.
} 
was developed in the context of S. Freud's psychoanalysis and other researchers. The forms of behavior that can be used for protection such as negation regression, rationalization, suppression, and other functions and mechanisms were defined. However, an existing problem is not solved by their means, instead, only temporary emotional well-being is achieved. Therefore, protective mechanisms can perform their adaptive function if they are used as one of the temporary means of regulating human behavior in difficult situations ${ }^{25}$.

These criteria were tested using "The methods of determining destructive installations in interpersonal relationships", "The methods of diagnosing hostility", "The methods of diagnosing the typology of psychological protection", "The test of the diagnosis of aggressive behavior", "Express diagnosis of the level of an individual's social isolation".

Thus, the following psychodiagnostic techniques are used:

1. The method of diagnosis of social empathy refers to social empathy. This is understood properly as a mechanism of social perception based on conscious or unconscious identification, the ability to compare oneself, one's personality, states and behavior which shows in an effective attitude towards them. The emotional response depends on if perceived the feelings of others adequately and the reasons that caused them. The methodology consists of 33 statements, provides binary levels of agreement and aims at identifying emotional sensitivity to the experiences of others in different life situations. The main aim is to determine the level of empathy tendencies. The index of empathy is determined by adding replies "yes" and "no" according to a key. Thus, the chosen method allows analyzing such a parameter as the social empathy of the representatives of ethnic-speaking groups more thoroughly.

2. The method of diagnostics of the polycommunicative empathy level consists of 36 statements. Each statement involves one answer of 8 variants which allow establishing the characteristics of particular components of empathy and the level of each component. The effective communicative interaction depends on the ability of a person to accept the role of another individual. That is determined by the level of development of cognitive empathy in the process of human perception. This means the

\footnotetext{
25 Фрейд 3. Психология масс и анализ человеческого «Я» / 3. Фрейд. - М. : Академический Проект, 2011. - 123 с. - (Психологические технологии).
} 
subject should rise above the subjective, "to take into account the needs and interests of "another" and thereby overcome the bias towards it.

3. The methodology of diagnostics of the personal installation "altruism-egoism" aims at studying the socio-psychological installation of personality and the detection of altruism. According to the methodology, binary variants of an answer ("yes" or "no") for 20 questions are provided. If the sum of points is more than 10, in the majority this expresses altruism and willingness to help or conversely, if less than 10 then this is the greater demonstration of selfish tendencies.

The methodology in this research is used to study the personality mindsets to altruism or the demonstration of egoistic tendencies which are showed by a certain criterion of social perception and in intergroup interaction as one of the definite characteristics of the subject in our study.

4. The method of express diagnosis of the level of social isolation of the individual (D. Russell and M. Ferguson). According to the proposed instruction, that consists of 20 statements and provides 4 variants of the answer. The main goal is to determine the index of egocentrism, the level of an individual's self-centered orientation, and centering on oneself. These are demonstrated by counting of sentences that contain the information about the subject and are expressed by the pronoun or the verb of the singular first person.

5. The methodology aims at identifying destructive mindsets in interpersonal relationships (V.V. Boyko), by the condition of which the binary variants of an answer ("yes" or "no") for 25 questions are provided. They allow identifying veiled cruelty, negativism in judgments, the personal experiences of negative communication with others, and the ability to set fingers of negative communicative mindsets.

6. The methodology of the diagnostics typologies of psychological protection (R. Plutchyk in the adaptation of L.I. Vaserman, O.F. Yerysheva, O.B. Klubova, etc.) that consists of 97 statements and provides a binary level of agreement. This aims to determine the main types of egodefense by 8 scales (negation, projection, regression, displacement, compensation, substitution, intellectualization, and reactive formations).

7. The method of the hostility diagnosis (by the Cook-Medley scale) which consists of 27 statements and provides 6 variants of an agreement level. This allows setting the level of indicators of the intensity of the 
relationships by the scale of cynicism, aggression, suspicion, hostility toward others.

8. A test for a diagnosis of aggressive behavior consists of 40 statements. This aims the demonstration of superiority in force or its use concerning another person or group and the desire to cause harm (BussDurkey Inventory adapted by L.G. Pochebut). The statement requires a binary assessment that involves their distribution by the following scales: verbal aggression, physical aggression, objective aggression, emotional aggression, self-aggression. Determination of the level of aggression by this methodology can help to do the analysis of interethnic conflicts, the possibility of prevention and stabilization of the social situation in polyethnic communities.

9. The methodology for a diagnosis of the motivators of the sociopsychological individual's activity consists of 15 assertions. It is necessary to identify 5 degrees of the agreement which are based on the theory of motivation by $\mathrm{D}$. McClelland. It helps to identify the central needs and motives of an individual. The effectuality applying of this method is confirmed by the obtained results that help to indicate the peculiarities of the socio-psychological activity of the individual in intergroup communication.

10. The methodology for a diagnosis of motivational orientations in interpersonal communication (I.D. Ladanov, V.A. Urazaeva) consists of 20 statements that require 4 levels of agreement according to the orientation-orientation scale and aims at determining of the main communicative orientations and their harmony in the process of formal communication. This technique should help to research more closely the motivational component of interpersonal communication. In our opinion, this reflects one aspect of social interaction the definition of communicative orientations particularly.

11. The method for a diagnosis of Acceptance of Others (by Fey's Scale) which includes 18 direct and reverse statements requiring 5 variants of response according to the proposed scale. This aims to study the degree of intensity of relationships and the peculiarities of accepting others.

12. The method is the Mehrabian Affiliation Tendency Questionnaire (A. Mehrabian) that consists of two scales by 30 and 32 statements and provides 7 levels of agreement. This is intended to identify two motives of a person, namely, the necessity to be accepted by others, interact closely 
with them, the fear of being neglected by others, therefore, internal discomfort and tension. All methods mentioned above are borrowed from the collection of psychological tests edited by N.P. Fetyskin.

13. The truthfulness of the responses was checked by the diagnostic methodology of self-assessment approval motivation (Marlowe-Crowne Social Desirability Scale). An option of the scale of desire to approve socially-desirable responses, desire to get support from others with statements and actions, to look like according to social norms provides a binary answer 20 statements $^{26}$.

\section{The factor structure of the communicative profile for the youth of the south-east region of Ukraine}

There were 180 examinees out of students of 3-5 courses who took part in this study. They were from three general-humanitarian institutions of different specialties (economic, pedagogical, legal, hotel, tourism services) which are located in Berdyansk city (Azov Regional Management Institute of Zaporizhzhya National Technical University, Berdyansk State Pedagogical University, Berdyansk University of Management and Business). The age of respondents was in the range 19 through 23 years old. As for gender, the respondents of both sexes were equal relatively with a slight predominance of the female sex.

There were several reasons to choose the student audience specifically for this study. Firstly, this is the most active social group. Secondly, in the student's age, the social and cognitive mechanisms of a person become relatively stable. Thirdly, a person at this age usually acquires a national and ethnic identity.

It is also taken into account that Berdyansk city and Berdyansk region is characterized as a polynational and polylinguistic region. The preferred language in a family can be not only Russian and Ukrainian but also Bulgarian, Greek, Azerbaijani, etc.

The tool base for this study was a set of 13 test methodologies and methods of statistical analysis of results through standard procedures using the computerized system for processing statistical data SPSS 20.0. Based on indicators of the methods mentioned above a questionnaire including 433 questions was made and proposed to the examinees. All scales were unified, which means they were brought to one form of an answer, which

${ }^{26}$. Психологические тесты / сост. С. Касьянов. - М. : Эксмо, 2006. - 608 с. - С. 358-360. 
has five variants of view evaluation (strongly agree, partially agree, neutral, partially disagree, strongly disagree). The responses of respondents were recorded in a special table.

Note that the factorization of the data was carried out by the method of the main component with Varimax rotation and with Kaiser Normalization. To verify the applying measures of factor analysis for this selection, the criterion of the adequacy of the Kaiser-Meyer-Olkin (0.683) selection and the Bartlett sphericity criterion (0.000) which determines the normality of the distribution of the variables were used. The interpretation of data was based on average values. The factor structure of the young students' communicative preferences that are from the south-eastern region of Ukraine was built.

The results of factor analysis of obtained empirical data allowed distinguishing the greatest number of connections between the level of polycommunicative empathy, the personal installation "altruism selfishness", the acceptance of others, motivators of social and psychological activity of an individual, the motives of affiliation, selfassessment of the motivation of approval.

They allow identifying some features of the communicative profile of young students. These features present its socio-psychological portrait in terms of the specifics of social guidance in the process of social perception in a polynational social space to a certain extent.

According to the results of factor analysis with the use of secondary factorization, five factors were distinguished. A total scater of the results of factor analysis is $51.8 \%$.

The claims mainly from the methodology of diagnosing the social isolation of the individual represent the structure of the first single pole factor (explains $18.4 \%$ of the scater) which was called "Social Alienation".

The first factor identified the combination of such indicators: "People are around me, but not with me" (, 802); "I feel isolated from others" (,788); "I feel abandoned" (,788); "I feel dismissed and isolated by others" (,785); "I feel completely alone" (,782); "My social relations and connections are surface" $(, 733)$; "I do not have anyone to talk to" $(, 723)$; "There is no one to whom I could ask to" $(, 717)$; "I am no longer close to anyone" $(, 656)$ "It seems to me that people around do not like me" $(, 636)$.

They give us an idea of the easier ride of social ties and feelings of isolation, alienation, distrust, etc. Strengthening the alienation of youth 
from society, the state, its individualistic orientation, the desire to refuse to solve common social problems are observed in a large part of the tested youth.

Sure, this can be explained partly by the impact of the crisis state of the socio-economic and socio-political environment. However, from the other hand within this study, this pays attention to the presence of a distinction in the polyethnic space of cultural phenomena and their acceptance in "his/her" culture enhances the experience of "alien" feeling. That means, the notion of "stranger" becomes a key value in the intercultural communication as a result of the collision of usual and unusual. This prompts to understand it in the broadest sense as everything that is outside of the limits of understandable, ordinary and well-known phenomena. The opposite concept "his/her" extends to the range of phenomena around the world which a person perceives as familiar, usual, and taken for granted.

This has both positive and negative sides. The positive side is that members of "alien" culture are unconsciously separated from "theirs" which carries out a definitive function for a certain community to preserve its identity, integrity, and specificity. The negative side is that the more or less conscious desire to isolate some people from others, encourage contempt for others, and create obstacles for equal intercultural communication. This creates an alienation situation whereby there is an understanding of something new, unknown occurs through comparison with the usual and well-known phenomena from their own experience that lead to stereotyping and schematization of units of the social world.

The second single pole factor (explains $9.2 \%$ of the scater) was called "Affiliation motivation". This combines signs such as: "I can completely rely on sincerity of my companion" (, 767); "Both, my interlocutor and I, we try to please each other" $(, 734)$; "I like to spend time in conversation with him" (, 730); "I try sincerely to understand intentions of my interlocutor" (, 710); "My interlocutor considers me worthy of respect" $(, 694)$. The structure of this factor is represented by indicators of the methodology of diagnosis of motivational orientations in interpersonal communication. This gave reason to distinguish between such orientations an affiliate component as the most important in interpersonal communication. 
A personality seeks to identify certain social and psychological boundaries of existence to strengthen their stability. To do this, it tries to identify with a specific community. The necessity of ethnic security should be specified by the preservation, reproduction, and free development of the ethnic-community as ethnocultural integrity. Each provides there a positive identity to the desire for positive self-esteem, and by increasing the status and prestige of their community.

It is the ethnic identity that can provide a person with a sense of security and positive identity in a crisis society. Therefore, it is no wondering that ethnic identity as a kind of social identity is related to the greatest burden of the orientation of individuals in society.

The third factor was called "Verbal Aggression - Tolerance" and the total scater is $9.2 \%$. At first sight, it has a bipolar structure and includes criteria such as: "When I am angry, I cry out the most malicious vocation" (, 841); "I say a lot of obscene words" $(, 828)$; "I use a strong word in strong anger, I am swearing" (, 817); "Pornography is disgusting" (, 579); "Sometimes, instead of forgiving a person I try to retaliate" (, 424). The structure of this factor is represented by statements from various techniques that generally give an idea of invective behavior. However, the loyalty to pornography is demonstrated on the other pole that is quite understandable if we analyze the meaning of obscene words, swearing.

The tendency and aggression of youth are characterized by the superiority of verbal aggression and sexually colored context partly. The aggressive emotional state as a form of psychological protection in case a situation of the threat of personal identity and self-esteem is accompanied by a demonstration of hostility towards a particular object. In turn, they are led by processes of stereotyping and fixing of ideas about the created "enemy's image".

It is noteworthy that on the one hand, part of modern youth is characterized by rudeness in communication, fighting, reducing criticism to negative asocial behavior, and on the other hand, verbal aggression testifies not only to the desire to inflict psychological damage, the source of which may be the state of uncertainty, and frustration, etc. but and the desire to assert itself.

The fourth factor was defined as "Emotionality - Indifference" (the total scater is $7.8 \%$ ) and has a bipolar character, includes the following signs: "It is stupid to experience what is happening in a cinema or what 
you read in a book" $(, 801)$; "I worry very much when I watch movies" (,735); "I am a person who never cries" (713); "People tell me that I believe in everything" (, 593).

The structure of this factor is represented by statements of the various techniques included in it and reveal on the one hand, increased emotionality, sensitivity, empathy, and on the other their content reveals a certain emotional dullness, indifference, distrust, (obviously protective) bravado, deficiency depersonalized trust in the world at all.

The most vulnerable social group during the crisis is youth and children. They cannot oppose the circumstances of their experience which are not yet sufficient; their resources are not enough to choose an adequate strategy of overcoming behavior which promotes the spread of indifference, pragmatism, selfishness, indifference to others, ethnic intolerance, even cynicism in the youth. However, they are available to resort to protective mechanisms.

The fifth single pole factor (explains $7.2 \%$ scater) is named "Prejudice". It was formed by criteria of two methods - the diagnosis of hostility and the diagnosis of the acceptance of others. "Sometimes happens the situation that you do good things to people and later regret, because they pay ingratitude" (765); "People do not always treat others honestly" (726); "The majority of employees at companies and institutions are trying to suck out everything that lies in temptation's way" (679).

Their content makes us a distrust of the "other" as a consequence of causal attribution, attribution to other negatives (in this particular case) motives, behavior, etc. Prejudice permeates the various aspects of social life both at the level of interpersonal relations and at the level of ethnic and linguistic communities. It can cause negative effects and intergroup perceptions, such as stigmatization, misunderstandings, conflicts, and discrimination based on language or belonging to a particular ethnic group, and limiting the positive experience of social contacts.

\section{CONCLUSIONS}

Therefore, the obtained data allow us to build a factor structure and to describe some important socio-psychological features of the communicative profile of young students from the south-eastern region of Ukraine. The attention is drawn to the fact that, there is also the 
transformation of the ideas of young people about ethical norms, life guidance and values and ways to achieve their students against the backdrop of ongoing changes in the social and political structure of society, changes in the direction of social individualism, primarily because of the significant differentiation of the population by economic, ethnic and political characteristics.

The content of the factors "Social exclusion", "Affiliated motivation", "Verbal aggression - Tolerance", "Emotionality - Indifference" and "Prejudice" and the distribution of assessments within their basic characteristics indicate tendencies to weaken social ties, social and political indifference and strengthening the feeling of isolation, alienation, distrust. The understanding of something new, unknown occurs through comparison with familiar and known similar phenomena from their own experience. This leads to a general state of alienation, a biased attitude, and a frequent choice of aggression as a means of regulating relations with the environment.

At the same time, the affiliate component was distinguished in communication as extremely important for interpersonal communications which actualize the need for social connections - solidarity, identity, and membership in the group in the structure of motivational orientations. A person seeks to identify certain social and psychological boundaries of his existence to strengthen and sustain his stability.

Consequently, the phenomenon of intergroup perception is due not only to real intergroup relationships but also to the social context. Ethnic communities take the lead among the plurality of socio-psychological categories: social loss, social roles, political preferences, etc.

The definition of the communicative profile of youth will allow to some extent present its socio-psychological portrait from social guidance in the process of social perception in the polyethnic and polylinguistic social space.

\section{SUMMARY}

The work is devoted to the definition of socio-psychological features of the communicative interaction of Ukrainian youth, especially the southeast that is characterized as a polynomial region.

The paper deals with the identification of a set of interrelated and most significant features of a factor structure of the communicative profile of 
young students which allows us to describe comprehensively the object of the study.

It is noted that the differentiation of society based on reference, the strengthening of ethnic and linguistic intolerance leads to the exasperation of social contradictions. The growth of inter-ethnic tensions highlights the necessity for social connections - solidarity, identity, group membership, promotes the adaptive ways of people's behavior which have become fixed as the most successful in the past. This conception interacts with the educational formations and forms conative (behavioral) structures of ethnicity that specify the methods of intragroup organization and mobilization.

The content of factors and the distribution of ratings within their main features indicate tendencies to easing of social ties, generally social, political indifference, and reinforce the sense of isolation, alienation, and distrust. It is determined that phenomena of intergranular perception are caused not only by real intergroup relationships but also by social context.

\section{REFERENCES}

1. Агеев В. С. Межгруповое взаимодействие. Социально-психологические проблемы / В. С. Агеев. - М. : МГУ, 1990. - 240 с.

2. Антонян Ю.М. Криминальная патопсихология / Ю.М. Антонян, В. В. Гульдан. - М. : Наука, 1991. - С. 129-139.

3. Васильченко О.М. Методи психосемантики в дослідженні соціальних уявлень / Ольга Васильченко // Соціальна психологія. 2004. - № 2 (4). - С. 19-37.

4. Васильченко О. Уявлення молодих українців про українців / Ольга Васильченко // Соціальна психологія. - 2003. - № 1. C. $123-133$.

5. Головаха Е.И. Социальные патологии посткоммунистического общества / Е.И. Головаха // Политическая мысль. - 1994. - № 4. C. 36-45.

6. Горностай П.П. Психологічний феномен «Ми» / П.П. Горностай // Соціальна психологія. - 2006. - № 2. - С. 88-96.

7. Данилюк І.В. Мова як чинник згуртованості групового «Ми» / І.В. Данилюк // Соціальна психологія. - 2008. - № 3. - С. 105-112.

8. Йонас Г. Принцип відповідальності. У пошуках етики для технологічної цивілізації / пер. 3 нім. - К. : Лібра, 2001. - 400 с. - 
Друк. за виданням : Jonas Hans. Das Prinzip Verantwortung. - Frankfurt am Main, 1979.

9. Колосов С.А. Манипулятивные стратегии дискурса ненависти / С.А. Колосов // Критика и семиотика. - Вып. 7. - Новосибирск, 2004. - C. 248-256.

10. Крысько В.Г. Социальная психология: словарь - справочник / В. Г. Крысько. - Мн.: Харвест, М. : АСТ, 2001. - 668 с. - С. 175-177.

11. Лебедева Н.М. Этническая толерантность в поликультурных регионах России / Н. М. Лебедева. - М.: Институт этнологии и антропологии РАН. - 2002. - 296 с.

12. Лозко Г.С. Етнологія України: філософсько-теоретичний та етнорелігієзнавчий аспект : навч. посіб. / Г. Лозко. - К. : АртЕК, 2001. - 304 c.

13. Лозова О.М. Мова в етнічній картині світу / Лозова О. М. // Вісник Київського міжнародного університету. Збірник наукових статей. - Серія: Психологічні науки.- Вип. 13. - К.: КиМУ, 2009. C. $110-123$.

14. Лозова О.М. Психосемантика етнічної свідомоті / О. М. Лозова - К.: «Освіта України», 2007. - 402 с.

15. Лозовая О.Н. Психология этнического сознания в Украине: история, настоящее, перспективы / Лозовая О. Н. // Историческая психология: истоки и современное состояние : Монография / под науч. ред. И.Н. Коваля, В.И. Подшивалкиной, О.В. Яремчук. Одесса: Одесский национальный університет им. И.И. Мечникова, 2012. - С. 115-129.

16. Платонов Ю.П. Основы этничной психологии Ю.П. Платонов. - СПб.: Речь, 2003. - 452 с.

17. Полани М. Личностное знание. На пути к посткритической философии / М. Полани. - М. : Прогресс, 1985. - 344 с.

18. Помиткін Е.О. Психологічні механізми духовного розвитку сучасного професіонала / Е. Помиткін // Соціальна психологія. 2010. - № 4. - C. 47-54.

19. Поршнев Б.Ф. О начале человеческой истории: (Проблемы палеопсихологии) / Б.Ф. Поршнев. - М. : Мысль, 1974. - 488 с.

20. Поршнев Б.Ф. Противопоставление как компонент этнического самосознания / Б. Ф. Поршнев. - М. : Наука, 1973. - 346 с.C. $163-184$. 
21. Поршнев Б.Ф. Социальная психология и история / Б.Ф. Поршнев. М. : Наука, 1979. С. 73-126. С. 84-96.

22. Психологические тесты / сост. С. Касьянов. - М. : Эксмо, 2006. -608 c. - C. $358-360$.

23. Слюсаревський М.М. «Ми» і «Я» в сучасному світі: Вибрані твори / М. М. Слюсаревський. - К. : Міленіум, 2009. - 340 с. C. $113-120$.

24. Фетискин Н.П. Социально-психологическая диагностика развития личности и малых групп / Н.П. Фетискин, В.В. Козлов, Г.М. Мануйлов. - М. : Изд-во Ин-та Психотерапии, 2002. - 490 с. С. 193-197.

25. Фрейд 3. Психология масс и анализ человеческого «Я»/ 3. Фрейд. - $\quad$ М. : Академический Проект, 2011. - 123 с. (Психологические технологии).

26. Шихирев П.Н. Современная социальная психология / П. Н. Шихирев. - М. : ИП РАН, КСП+, Академический Проект, 1999. -447 c.

\section{Information about the author:}

Bielavin S. P.

$\mathrm{PhD}$ in Social Psychology, Associate Professor at the Department of Psychology and Pedagogy of the Scientific and Humanitarian Institute of the V. I. Vernadsky Taurida National University 


\section{THE LEGAL SELF-DETERMINATION OF THE IMPOVERISHED SOCIAL GROUPS' REPRESENTATIVES}

\section{Bielavina T. I.}

\section{INTRODUCTION}

A special socio-economic structure was generated in the present socioeconomic circumstances against the background of breathtaking transformation in all spheres of social life. On the one hand, it is an excessive enrichment of certain, small part of the population and on the other hand, it is an impoverishment of significant part of the population who find themselves in economically deprived status. The part of Ukrainian society is unprepared psychologically for present changes which cause in ordinary person feelings of uncertainty, anxiety, and a sense of social insecurity.

This issue is particularly important because poverty is now widely spread. The majority of the population is poor including men and women of working age. Moreover, among them, a certain number have higher education and higher qualification. A specific social category of "working poor" was discovered. They receive a payment for their labor that does not secure the needed household income. In addition, the marginal section of the poor on a lowest level was formed including those who have special socio-psychological orientation such as the homeless, the beggars, the homeless children, the former prisoners, the representatives of groups belonging to non-productive subcultures, the poverty-stricken social groups (low-skilled workers with low education, with poor health, etc.).

In their consciousness, the representatives of the economically vulnerable social groups do not hold in a priority the respect and trust for the legal norms and requirements of the law, and the concept of civil rights and freedoms. On the contrary, many of them have a dominant idea that nothing depends on them and that the law is not able to protect them in the face of the new time challenges. The part of the indigent is characterized by a significant deficiency of legal awareness, distorted the legal self-determination, and perverted self-control. The consequences of the legal awareness distortion are the problems with the legal self-identification, his/her distrust to all social institutions, including state and legal ones. The close and complex 
interrelationship occurs between the economic plus legal awareness and the conditions for overcoming the economic deprivation.

It entails the necessity to determine what the factors are and how they influence the process of the legal self-determination of the poverty-stricken social groups' representatives, and groups with low economic status. It requires identifying the role of subjective factors of psychological gravity toward poverty in the legal self-determination of a person with deviations of the legal socialization.

\section{The social-psychological distinctions of the legal consciousness of the poverty-stricken groups' representatives}

The researches of the legal issues of the poverty are characterized by the variety of methodological principles for analysis of the correlation between the society's culture and the social group subculture, and also by the lack of more or less consensual understanding of how "far the person went astray on the way of alienation from the universally accepted norms and values"1,2,3. The numerous studies observe that those individuals who subjectively identify themselves with the poor, defenseless, losers more often excuse themselves for the unlawful inclination, individualism, and destructive emotions ${ }^{4}$. To the large degree that causes the illegal behavior of the individual and also the growth of the resistance to the legal system in society ${ }^{1,3,5}$. In general, the poverty becomes a factor of the human rights violation and an important prerequisite to deficiency of legal awareness, so called "social crudeness of public opinion" of such groups ${ }^{7,8}$.

\footnotetext{
${ }^{1}$ Гилинский Я. Девиантология: социология преступности наркотизма, проституции, самоубийств и других «отклонений» / Я. Гилинский. Девиантология. - СПб.: Издательство «Юридический центр Пресс», 2004. - 520 c.

${ }^{2}$ Ильин И.А. О сущности правосознания / Теория права и государства / И.А. Ильин. - Моск. гос. ун-т им. М.В. Ломоносова. Юрид. фак. - Москва: Зерцало: Система Гарант, 2003. - 398 с.

Петров В. Р. Деформация правосознания граждан России (Проблемы теории и практики): дис. ... канд. юрид. наук: 12.00.01- М. : РГБ, 2002 [Электронный pecypc: http://diss.rsl.ru/diss/ 02/0002/020002597.pdf ]

4 Муздыбаев К. Переживание бедности как социальной неудачи: атрибуция ответственности, стратегии совладания и индикаторы депривации / К. Муздыбаев // Социологический журнал. - 2000. № 3/4. - С. 36 .

5 Гулевич О.А., Голынчик Е.О. Правосознание и правовая социализация. Аналитический обзор / О.А. Гулевич, Е.О. Голынчик. - «Психология». Москва: Международное общество им. Л.С. Выготского. - 2003. - 270 с.

${ }^{6}$ Петровская Т. Соціально-психологічні фактори економічної поведінки / Петровская Т. // Соціальна психологія. - 2004. - № 4(6). - С. 23-35.

Петров В.Р. Деформация правосознания граждан России (Проблемы теории и практики): дис. ... канд. юрид. наук: 12.00.01 - М. : РГБ, 2002 [Электронный pecypc: http://diss.rsl.ru/diss/02/ 0002/020002597.pdf ]

8 Гулевич О.А., Голынчик Е.О. Правосознание и правовая социализация. Аналитический обзор / О.А. Гулевич, Е.О. Голынчик. - «Психология». Москва: Международное общество им. Л.С. Выготского. $-2003 .-270$ с.
} 
The anti-social behavior is often associated with poor people or communities belonging to non-productive subcultures according to economic criterion. Usually, the representatives of the poorest, marginalized groups are related to the crime in its various manifestations, vagrancy, drug addiction, alcoholism, and other deviations. They are the results of isolation from social life and the exclusion from the generally accepted lifestyle which is directed to the socialization, and that separation leads to breaking social bonds or lack of them.

The realities of the current life predetermine a significant distortion of a person's value system, his beliefs, and attitudes. The proper ideas were developed in the researches that discuss the deficiency of the legal awareness of citizens. The generally accepted understanding of such a deformation presupposes the existence of certain legal opinions, knowledge, attitudes, which transformed into non-legal constructions and at the extreme degree of distortion into criminal consciousness. The researchers of legal consciousness suggest different forms of classifications of distortion. For example, Y. Vedernikov emphasizes such forms as legal ignorance, legal idealism, legal nihilism, degeneration, legal dilettantism, and legal doublespeak.

Usually, among the representatives of social groups with the lower economic status, the following widely spread types are recognized: 1) legal ignorance - it is understood as an insufficient level of legal knowledge and attitudes plus the difficulties in legal self-determination. It is a lack of positive and respectful approach to the law and other legal values; 2) legal idealism - it consists in inadequate attitude to the law, and excessive expectations that the adoption of the needed law solves all problems; 3) legal nihilism - it is conscious ignoring of the law's requirements including criminal intent to violate the law, and conviction that person has to be governed not by the law but self-interest; 4) degeneration - it is the lowest level of distortion of the defective legal consciousness to the point that it poses danger to the public. It is characterized by a conscious refusal of the law based on self-interest, cruelty, and greediness 9 .

Y. Gilinsky argues that such measures as raising the quality and standard of living plus the level of education do not per se contribute to reducing the crime or general criminalization of society. The crime is widespread among the well-off and respectable men as well as among the

\footnotetext{
${ }^{9}$ Ведерников Ю.А. Теорія держави та права : навч. посіб. / Ю. А. Ведерніков, В.С. Грекул. - К. : Центр навч. л-ри, 2005. - 224 с.
} 
poor but the object and the means to commit the crime are different. The legal impunity for the violation of the law is more inherent to the affluent men. Such a type of attitude to the law is deeply rooted in strong belief of a person in his own freedom from punishment for the violation either due to force (weapon, organized criminal group), or money (economic status), or power (corruption, social parasitism), or the combination of all these resources ${ }^{10}$.

In her studies on the interaction among delinquents, O. Khorina defined the types of resource interaction as following: altruisticsacrificial - it is sharing one's resources with others; selfish-consumer - it is exploitation of another person's resources; equivalent exchange of resources; destructive-isolation - it is social isolation (neither I nor for me). Most problems arise with the destructive-isolation type of resource interaction when a person suffers from a lack of a certain resource, but can not make a request or accept a resource from another. Such a lack hinders the sharing of the resources and increases the risk of self-destruction ${ }^{11}$.

The economic consciousness of the subject determines the external manifestations of his economic activity and can have a significant impact on its course, results, and consequences. We suppose that people, who have limited access to economic and other resources for achieving their goals, more likely discover that they have a competitive disadvantage comparing to people who are more affluent and have a certain status. If an economically deprived person does not realize his/her resources to succeed he/she is looking for common problems, hostility, and aggression through which he/she exposes the external style of self-regulation, and resorts to self-justification of his/her irresponsibility, lack of initiative, disregard to the requirements of important moral and legal norms, and thus, he/she demonstrates legal nihilism. A recompensed search of faith in goodness partially assists and even faith in an essence of religion helps. For example, it is precisely among representatives of poverty-stricken social groups that "hope for God" dominates significantly as an additional resource for optimizing attitudes and self-esteem of an individual.

\footnotetext{
${ }^{10}$ Гилинский Я. Девиантология: социология преступности наркотизма, проституции, самоубийств и других «отклонений» / Я. Гилинский. Девиантология. - СПб.: Издательство «Юридический центр Пресс», 2004. - 520 c.

11 Хоріна О.І. Дестуктивні моделі міжособових стосунків підлітків. Наукові студії із соціальної та політичної психології: Зб. Статей / АПН України, Інститут соціальної та політичної психології; Редкол.: С.Д. Максименко, М.М. Слюсаревський та ін. - К.: Міленіум, 2008. - Вип. 19 (22). - С. 111-123.
} 
The relationship between law and morality is significant in the legal self-determination process. L. Petrazhitsky is the author of the psychological concept of the law, and he divided the law into two major categories: on the official law and the intuitive law. The official law is authorized by the state. The intuitive law is connected with experiences, morality, and spirituality. He believed that the law is an emotional phenomenon. He argued that "the basis for the intuitive law (legal consciousness) is justice" 12 .

The results of the studies on this topic demonstrated that the concept of "justice" occupies a more important place than legal norms in the legal consciousness among the representatives of poverty-stricken social groups. Weakening the uncritical attitude to legal requirements and sanctions stands in correlation to the degree of agreement with the general principles of morality and justice. The poor more often are guided by moral principles and ethics than other respondents. If the principles of the legal system do not correspond with their value system, moral and ethical norms, then they hold that the laws should be changed.

\section{Social-psychological interdependence between the poverty and legal self-determination process}

An empirical study was aimed at ascertaining the interdependence between the legal self-determination and the level of psychological gravity toward poverty, belonging to a non-productive subculture, identifying the link between objective indicators of the deficit of the economic resource and psychological inclination to poverty. An integrated approach to socio-psychological tools explains the use of methods: theoretical analysis, interviewing, testing, projective techniques, socio-psychological training, game modeling, systematization and synthesis of the data.

At the first step, the selection, approbation, and correction of methodical tools were executed. At the second step, the sociopsychological peculiarities of the legal consciousness and the legal selfdetermination were specified concerning persons who belong to nonproductive subcultures. The poor are attributed to these subcultures. At the third step, correction-development methods were used to optimize the

\footnotetext{
12 Петражицкий Л.И. Теория права и государства в связи с теорией нравственности Л.И. Петражицкий. - СПб.: Издательство «Лань», 2000. - 608 с.
} 
process of the legal self-determination of the poverty-stricken social groups' representatives.

The socio-psychological study tools included: a test for the diagnosis of the personality attitude called "altruism-selfishness" that is aimed at investigating the orientation of personal attitudes; test for the diagnosis of social-psychological activity motivators that was composited on the basis of the motivation theory created by D. McClelland; A. Mehrabians test that is directed towards the identification of affiliation motives; MarloweCrowne approval motivation test. These techniques are borrowed from the collection of psychological tests edited by M.P. Fetyskin ${ }^{13}$

The lifestyle specific character of people with low economic status and their psychological state have been studied by such methods as "Lifestyle self-assessment of people with different economic status", "Typology of subcultures of dissatisfaction" by N. Kalina ${ }^{14}$ and the questionnaire "Psychological gravity toward poverty" by V. Vasutinsky (hereinafter referred to as PGTP) ${ }^{15}$.

One of the purposes of this study was to determine a connection between psychological gravity toward poverty and the peculiarities of the legal self-determination in the formation process of the cognitive, affective and behavioral components of the legal consciousness. It was completed through the studies of the attitudes to the law in the social stratum by interviewing methods, projective techniques, questionnaires in the version of O. Gulevich, O. Golynchik ${ }^{16}$, and questionnaire of PGTP ${ }^{17}$. Also, the "Scale of conscience" composed by V.V. Melnikov, L.T. Yampolsky was used to determine the degree of respect for social norms and ethical requirements: responsibility, integrity, the stability of moral principles ${ }^{18}$. The questionnaire of V.I. Morosanova, that is called "The style of behavior

\footnotetext{
13 Фетискин Н.П. Социально-психологическая диагностика развития личности и малых групп / Фетискин Н.П., Козлов В.В., Мануйлов Г.М. - М.: Изд-во Ин-та Психотерапии, 2002. - 490 с. C. 193-197.

${ }_{14}$ Каліна Н.Ф. и др. Лики ментальности и поле политики: Монография / Н.Ф. Калина, Е.В. Черный, А.Д. Шоркин - К. : Агропромвидав України, 1999. - 184 с., - Библиогр.: С. 167-171.

15 Васютинський В.О. Стиль життя як соціально-психологічна характеристика культури бідності / Васютинський В.О. // Наук. студії із соц. та політ. психології: Зб. статей / НАПН України, Ін-т соц. та політ. психології. - К., 2012. - Вип. 30 (33). - С. 19-32.

${ }^{16}$ Гулевич О.А., Голынчик Е.О. Правосознание и правовая социализация. Аналитический обзор / О.А. Гулевич, Е.О Голынчик. - «Психология». Москва: Международное общество им. Л.С. Выготского.2003. $-270 \mathrm{c}$.

17 Васютинський В.О. Стиль життя як соціально-психологічна характеристика культури бідності / Васютинський В.О. // Наук. студії із соц. та політ. психології: Зб. статей / НАПН України, Ін-т соц. та політ. психології. - К., 2012. - Вип. 30 (33). - С. 19-32.

18 Фетискин Н.П. Социально-психологическая диагностика развития личности и малых групп / Фетискин Н.П., Козлов В.В., Мануйлов Г.М. - М.: Изд-во Ин-та Психотерапии, 2002. - 490 с. C. 193-197.
} 
self-regulation", was applied for studies of various aspects of individual self-regulation ${ }^{19}$. Furthermore, the objective criterion is taken into account, namely, the economic indicator of the income level per family member.

One of the tasks of the studies was to determine the correlative relationship between the data received in the questionnaire of $\mathrm{PGTP}^{20}$ and the results obtained by the methodology of $\mathrm{N}$. Kalina ${ }^{21}$ as well as the degree of conformity of subjective and objective poverty indicators.

In general, 673 people aged 18 to 77 years, with a small prevalence of older women took part in the studies at various stages. They are residents of Kyiv city, and also Zaporizhzhia, Kyiv, Poltava, and Sumy regions. According to the level of material welfare (before the rise of salaries and pensions), the test subjects were distributed as follows: the low level - up to 2 thousand UAH. Monthly income per family member - $43.7 \%$, average - from 2 to 3 thousand UAH. - 24.7\%, high - from 3 thousand UAH. $-31.6 \%$. In line with the results of the questionnaire of PGTP the high level of psychological gravity toward poverty (63.9\%) prevails among people with low economic status, but individuals with high material income have a low level of PGTP (19.4\%, the difference is significant at $\mathrm{p} \leq 0.05)$. The comparison of objective and subjective criteria of poverty has confirmed the close connection between the objective indicators of the material welfare and the psychological gravity toward the poverty of people who choose poverty as a lifestyle.

The selection of the most informative methods under the stated objections was accomplished through interviewing 180 students of the 3-5-year study of economic, pedagogical and law specialties from the three higher institutions of Berdyansk city, and Zaporizhzhia region. The age of respondents ranges from 19 to 23 years. By gender, the respondents were distributed relatively equally with a slight preference for females $(54.4 \%)$. The data obtained have been subjected to correlative and factor analysis. Thus, a final set of methods was defined and it includes such techniques as the test for diagnosis of the personality attitude, namely, "altruismegoism", the A. Mehrabian's test for the identification of the affiliation motives, V. Melnikov's "Scale of conscience", L. Yampolsky, Marlowe-

\footnotetext{
19 Моросанова В.И. Опросник «Стиль саморегуляции поведения» / В.И. Моросанова (ССПМ): Руководство // М.: Когито-Центр, 2004. - 44 с.

${ }^{20}$ Васютинський В.О. Стиль життя як соціально-психологічна характеристика культури бідності / Васютинський В.О. // Наук. студії із соц. та політ. психології: Зб. статей / НАПН України, Ін-т соц. та політ. психології. - К., 2012. - Вип. 30 (33). - С. 19-32.

${ }^{21}$ Каліна Н.Ф. и др. Лики ментальности и поле политики: Монография / Н.Ф. Калина, Е.В. Черный, А.Д. Шоркин - К. : Агропромвидав України, 1999. - 184 с., - Библиогр.: С. 167-171.
} 
Kraune approval motivation test ${ }^{22}$, the multi-layered technique by V. Morosanova or "The style of behavior self-regulation ${ }^{23}$, PGTP test ${ }^{24}$, projective method of O. Gulevich, O. Golynchik ${ }^{25}$, N Kalina's method that is called "Typology of Subcultures of Dissatisfaction" 26.

The application of these methods allowed to determine the construct of moral and legal self-consciousness (motivational-value, cognitive and reflexive components) of persons with various degrees of psychological gravity toward poverty. The research was carried on a sample of 247 respondents aged 18 to 45 and among them were $53.4 \%$ women. Indicators of material well-being were specified showing that $21.4 \%$ of respondents had up to 1 thousand UAH., from 1 to 2 thousand $-22.3 \%$, from 2 to 3 thousand UAH. $-23.7 \%$, from 3 to 4 thousand UAH. $-14.6 \%$, more than 4 thousand UAH. $-17 \%$.

According to the results of the factor analysis of the obtained data, five factors were distinguished (the combined dispersion was 50.6\%), and their content characteristic emphasized the distinctions concerning the rights, morality, justice, self-regulation, and the integrity of individuals who choose the poverty as a lifestyle.

The first single-pole factor is "Responsible efficiency" (contribution to the variance is $11.1 \%$ ). Our study revealed the highest manifestation of the first factor in the group with an income level between "up to 3000" and "more than 3000 " ( $\mathrm{p} \leq 0,1)$. The smallest manifestation of the first factor was in the groups with the lowest and highest level of the income. It paradoxically united the social categories with various economic levels. It appears that "Responsible effectiveness" is the least important for the poorest who believe that nothing depends on them and someone has to take care of them.

The second factor was identified as "Control" (10.3\%). The third and fifth bipolar factors were identified as "Trust - Anxiety" (10.1\%) and

\footnotetext{
22 Фетискин Н.П. Социально-психологическая диагностика развития личности и малых групп / Фетискин Н.П., Козлов В.В., Мануйлов Г.М. - М.: Изд-во Ин-та Психотерапии, 2002. - 490 с. C. $193-197$.

${ }^{23}$ Моросанова В.И. Опросник «Стиль саморегуляции поведения» / В.И. Моросанова (ССПМ): Руководство // М.: Когито-Центр, 2004. - 44 с.

${ }^{24}$ Васютинський В.О. Стиль життя як соціально-психологічна характеристика культури бідності / Васютинський В.О. // Наук. студії із соц. та політ. психології: Зб. статей / НАПН України, Ін-т соц. та політ. психології. - К., 2012. - Вип. 30 (33). - С. 19-32.

${ }^{25}$ Гулевич О.А., Голынчик Е.О. Правосознание и правовая социализация. Аналитический обзор / О.А. Гулевич, Е.О. Голынчик. - «Психология». Москва: Международное общество им. Л.С. Выготского.-2003. -270 с.

${ }^{26}$ Каліна Н.Ф. и др. Лики ментальности и поле политики: Монография / Н.Ф. Калина, Е.В. Черный, А.Д. Шоркин - К. : Агропромвидав України, 1999. - 184 с., - Библиогр.: С. 167-171.
} 
"Altruism - Selfishness" (9\%). Significant differences between the groups with varied income according to the data that indicated the second, third, and fifth factors were not detected.

The fourth bipolar factor was identified as "Justice" $(10,1 \%)$. It showed significant differences between the groups with the income "up to 1000 " and "more than 3000 " ( $\mathrm{p} \leq 0,1)$, and also between the groups with the income "up to 2000" and "more than 3000 " ( $p \leq 0.05)$. The lower is the profit the more important is justice from a subjective point of view. The wealthier people consider themselves free from legal and moral norms. They are less willing to accept them as their duty.

Consequently, the construct of moral and legal self-awareness of individuals with a certain degree of psychological gravity toward poverty focuses on such characteristics as responsibility, control, trust and anxiety, justice, altruism, and selfishness.

The results analysis of the application "Scale of conscience" method on the same sample revealed that persons with a high level of psychological gravity toward poverty $(p \leq 0.05)$ were more conscientious and law-abiding (according to the conformal type). They are characterized by good conscience, a desire to keep to social requirements that is usually united with self-control. Self-control and self-regulation are the most important aspects of the legal self-determination of a person.

The results obtained by "The style of behavior self-regulation" method indicate the development level of individual system of the human activity self-regulation. The average and low general levels of selfregulation $-59.4 \%$ and $33.7 \%$ respectively are more typical for the respondents with low economic resources and a high level of psychological gravity toward poverty. A high level of self-regulation was detected only in $6.9 \%$ of cases.

Therefore, individuals, who suffer from a lack of material resources and demonstrate a willingness to be poor, are characterized by the low ability to self-regulation and reflexivity, conformity, and propensity to manipulate. At the same time, they have the ability to the detailed assessment of the situation, endeavor, and initiative in communication. The persons with an average level of psychological gravity toward poverty can set goals, to plan, to keep a deadline for completing the tasks. They are inherent to psychological flexibility, innovation. 
The belonging of the respondents to the subculture of poverty was confirmed by N. Kalina's "The typology of subcultures of dissatisfaction" method $^{27}$. The studies were carried on a sample of 117 citizens from Kyiv city and Berdyansk, and Zaporizhzhia region aged 18 to 59 years with a small preference of retired women (57.3\%). Among them were unemployed, pensioners, and representatives of different professions. The typology of subcultures of dissatisfaction has been identified based on the scales (according to N. Kalina, p. 113-117). The typology includes six sociotypes: "lucky", "master-happy", "idle-militant", "master-stricken", "idle-downcast", "absurdist". Based on two universal characteristics of the activity, namely, intensity and productivity and their combinations these sociotypes were combined into three groups. The first group comprised "lucky" and "master-happy" sociotypes due to the indicators of intensive and productive activities. It was named "Satisfaction" (28.2\%). The second group was combined based on intensive but unproductive activities. It was called "Psychological protection". It included such sociotypes as "idlemilitant" and "master-stricken" (29.1\%). The third group was called "Pessimism" and was singled out due to the indicators of non-intensive and unproductive activities. It includes such sociotypes as "idle-downcast" and "absurdist" (42.7\%).

Indicators of objective economic status in the isolated groups were distributed in this way: in "the Satisfaction group" the low income have $43.2 \%$ of respondents, the average $-27.0 \%$, the high $-29.7 \%$; in "the Psychological protection group" $44.1 \%$ of respondents gain low income, an average $-23.5 \%$, and a high $-32.4 \%$; in "the Pessimism group" the majority of respondents have a low level of material well-being (55.6\%), the average level has $16.7 \%$ of respondents, and the highest level of income maintain $27.8 \%$ of respondents.

The test of incomplete statements was used to study the attitudes to the law functions, the possibilities of its amendment, the conditions of law observance and the probability of its violation by persons with different economic status. The test was elaborated by O. Gulevich and O. Golynchik ${ }^{28}$ based on a model of legal development. According to this model, there are three types of legal development like law-abiding, law

\footnotetext{
${ }^{27}$ Калина Н.Ф. и др. Лики ментальности и поле политики: Монография / Н.Ф. Калина, Е.В. Черный, А.Д. Шоркин - К. : Агропромвидав України, 1999. - 184 с., - Библиогр.: С. 167-171.

28 Гулевич О.А., Голынчик Е.О. Правосознание и правовая социализация. Аналитический обзор / О.А. Гулевич, Е.О. Голынчик. - «Психология». Москва: Международное общество им. Л.С. Выготского. $-2003 .-270$ c.
} 
support and law-making. Those who are at the first level of the legal development perceive "the law" and "morality" as being inseparable. The norms are observed not based on unconscious acceptance of principles but due to emotional and value attitude to the law and legal sanctions. At the second level, the person abides by the law to meet social expectations. A person at the third level is guided not by the actual laws but the general principles of the legal system's existence (Gulevich).

The test consists of the four incomplete sentences concerning an understanding of the basic functions of the law, the possibility of changing the law, the reasons for the observance of the law, the probability of its violation. Each sentence is accompanied by four variants of answers three of which consistently reflect three types of personal legal development law-abiding, law support and law-making. The fourth option allows completing the sentence with personal opinion. Furthermore, the results obtained from the representatives of all three subcultures of dissatisfaction are compared.

The first incomplete sentence says "The main function of the law is ...". It has the following answers: a) the punishment of people who violate social norms and are dangerous for others; b) a support of the state's vitality, prevention of behavior, aimed at its destruction; c) an advance the life of certain people and the entire state; d) personal view.

The distribution of responses reveals that more than one-third of the representatives of all three groups consider that the main function of the law is the punishment, and abiding by the law is possible only through prohibition. They do not doubt the perfection of the law and are convinced that people comply with the law out of fear of punishment. Their level of legal development is law-abiding.

The relative majority of the representatives of "the Satisfaction group" (44.1\%) consider that the main function of the law is to support the fundamentals of the state. The attitude to the legal requirements reveals that they are considered as the result of the common consent of people, conformism, and the desire to meet social expectations. The response indicators of such groups as "the Psychological protection" (33.3\%) and "the Pessimism" (37.3\%) were slightly lower than the respond indicators of "the Satisfaction group" but in the line with tendency. In general, such attitude characterizes those who are at the level of law support. 
The assessment of the law as a means of advancing the lives of individuals causes skepticism among representatives of all three groups. Comparatively more respondents are in "the Psychological protection group" $(30.3 \%)$ who assume that this is the main function of the law. The relatively high law-making level of legal development in this group can be partially explained by the bigger number $(76.5 \%)$ of people with higher education in this group - in other words, they are more knowledgeable.

The second incomplete sentence says "Changing the law...", and has the following variants of answers: a) is inadmissible under any conditions; b) possible if the law destroys the fundamentals of the state, impedes its development; c) possible, if the law is unfair, and does not correspond to the basic moral norms; d) personal view.

The first variant of the answer was more often chosen by respondents of "the Pessimism group" $(20.0 \%)$. On the contrary, more than half of the representatives of "the Satisfaction group" (61\%) and "the Psychological protection group" (62\%) significantly more than the respondents of "the Pessimism group" (in both cases $\mathrm{p} \leq 0.05$ ) consider that it possible to change the law if it destroys the fundamentals of the state and hinders its development. About two-fifths of respondents in all groups assume the possibility of changing the law if it is unfair. Such results indicate distrust to the existing legal reality that manifests itself in the non-recognition of legal norms, demands, and sanctions since the subjects of such a behavior question the ability of the law to protect rights and freedoms for they do not believe in its justice.

The third incomplete sentence says "People mostly abide by the law because ...", and the test provides the choice from the following variants of answers: a) they fear punishment for violations of the law or want to reap the benefit of abiding in the law; b) they try to be like people around them, and do not want to violate the established rules or try to avoid the chaos that will be resulted from the violation of the law; c) they recognize that in general the law is fair, and corresponds to the basic moral norms; d) personal view.

More than half of the respondents in all three groups choose the first option considering that people are afraid of the punishment for violating the law or expect to reap the benefit of abiding in it. From a quarter to the sixth part of respondents of each group think that people are trying to be like the others, and do not want to violate the established rules or try to 
avoid chaos. This attitude becomes more definite with age. Each third, fourth or fifth respondent depending on the group recognizes that the law is fair and meets moral standards. The significant differences between groups in the evaluation of this test sentence have not been revealed.

According to the data obtained from the response on the fourth test sentence concerning the possibility of breaking the law the respondents quite often hold that it is inadmissible to change the law. Thus, they acknowledge its importance for the regulation of public life. In other words, they are guided by it in their actions and fulfill legal requirements. This opinion is especially popular among the representatives of "the Pessimism group" for half of them hold this view while in the other two groups only a quarter or a third part of respondents $(\mathrm{p} \leq 0,05)$ state it. Significantly fewer respondents suggest the possibility to violate the legal standards for maintaining the fundamentals of the state and its development, but the smallest number of such respondents is in "the Psychological protection group" ( $\mathrm{p} \leq 0,05)$. The majority of respondents see the need to change the law when it is unfair, but such respondents are relatively less in "the Pessimism group" $(\mathrm{p} \leq 0.05)$.

Summing up, we note that the conception of persons with different economic statuses about the interrelation of legal and ethical norms is not homogeneous. The types of perception of legal and ethical norms are determined by the assessment of their goals and effectiveness, and also in conformity with the levels of legal consciousness development like rationalistic, pessimistic, nihilistic, and idealistic. Rationalistic perception that prevails in "the Satisfaction group" is inherent to those who hold that the obedience to the law is necessary since it is a barrier for the destruction of the state fundamentals but it can be passed around if it is unfair. The persons, who perceive the law pessimistically (that attitude characterizes "the Pessimism group"), have uncompromising conception based on the general negative attitude and doubts in the possibility of a fair decision. They hold that the violation of the law is impossible, and abiding by the norms is mandatory. The nihilistic perception (it is inherent to the representatives of "the Psychological Protection group") characterizes those who deny the values of the law and do not believe that through obedience to the law one can establish justice. An idealistic view of the law ("the Psychological Protection group" and "the Pessimism group") specifies those who have a positive attitude to the law and its institutions, 
and believe in the integrity of the guardians of the law and the possibility of fair decisions.

The key to a culture of poverty is an awareness of "deprivation". The test subjects were divided into three groups according to the characteristics of the psychological state: "the Satisfaction group" is characterized by the general satisfaction from life; "the Psychological protection group" is predominantly ambivalent in its experiences; "the Pessimism group" is chiefly characterized by total dissatisfaction. The relationship between affiliation to a certain type of dissatisfaction subculture and the level of legal development is established: law-abiding is inherent to the representatives of "the Psychological protection group" and "the Pessimism group", law support is typical for "the Satisfaction group" and "the Psychological protection group", and law-making is deep-rooted in "the Satisfaction group".

Development of moral and legal orientations of people with the shortage of economic resources occurs in a state of constant socioeconomic inequality, aggravated by the prolonged economic crisis. Moral and legal orientations tend to both constructive and destructive development. The shortage of economic resources causes the subjective restoration of such undesirable norms and values as passivity, dependence, marginal consciousness. Individuals, who subjectively identify themselves as poor, helpless, and losers, more often than others make attempts to justify the unlawful attitudes, degradation, egoism and other negative features and qualities that to large extent lead to unlawful behavior and intensify the illegal attitudes.

\section{Legal self-identification of personality as a sphere of socio-psychological means application for preventing and overcoming the poverty}

One should take into consideration the following issues in determining the paths for positive socio-psychological influence on the legal selfdetermination of persons with low economic status: observance of human rights (provision, protection, participation); attitude to the law, and the legal and moral norms and sanctions; peculiarities of legal deformation and its correction: legal negativism, legal infantilism, legal nihilism.

The usage of corrective measures presupposes the development of the content and procedure for social-psychological training and imitation 
games (modeling law-making projects, rules, principles of coexistence in extreme circumstances) that are the most effective means for optimizing the legal consciousness of those who tend to the poverty plus for measuring the efficiency of their function. This correctional research also included approbation of the questionnaire to measure the action's effectiveness, socio-psychological training, imitation game, systematization and synthesis of the data.

For five studied groups, 129 people were drawn in for participation in activities. Three groups included unemployed who were registered in the Berdyansk city employment center of Zaporizhzhia region: a) in the group for socio-psychological training were 25 people, b) in the group for imitation game were 31 persons, c) control group was made up out of 19 persons. Also, a socio-psychological training for the students of the Kyiv Higher Professional School of Woodworking was organized - for 28 and 26 people accordingly. Participants in corrective-development activities were predominantly in groups with a shortage of economic resources, and also students were from poor families.

In each of the groups, while the control group was excluded, a oneday training or imitation game was organized using the impact program with a general name like "I have the right". The tasks of the sociopsychological training were to form an awareness that civic values and ideals are socially significant, and to enhance the ability to constructively defend personal civil rights; to acquire the knowledge and skills that can change ineffective legal attitudes and behaviour pattern; to actualize the notion of constructive interaction in a group, community, society; to optimize the system of legal and ethical norms expanding the scope of a person with regard to the legal culture.

The training session consisted of eight blocks and was run using exercises on interpersonal and intergroup communication with the implementation of innovative techniques (group discussion, brainstorming, role play, interpersonal training of effective behavior). Such special psychological techniques as self-knowledge, analysis, feedback, and reflection were developed during the training.

The imitation game method was used in one of the groups. It is an effective tool for optimizing the legal consciousness of those who tend to poverty. It is based on modeling projects of law-making, rules, principles of coexistence in extreme circumstances. The special functions of the 
imitation game make it possible to use role-playing techniques as a significant and influential means in correctional work. The interactive potential of the game is revealed through the freedom of participants' actions, submerging in the content of the game, obeying to certain rules, the development of a special, emotionally colored relationship. Scientific literature provides a wide range of game development, describes various aspects of playing activities, suggests how to use their potential, for instance, in the studies of M. Birshtein ${ }^{29}$, A. Verbitsky ${ }^{30}$, R. Zhukova ${ }^{31}$, G. Schedrovitsky ${ }^{32}$, L. Ivanenko ${ }^{33}$, and A. Panfilova ${ }^{34}$.

The imitation game is one of the interactive methods of cooperation in conditions of modeling an imaginary experimental situation (A. Panfilova, 2003). The object of play modeling is to create a situation with uncertain conditions. Thus, its goal is to develop the moral rules of relationship, a collective strategy for survival, a strategy for cooperation.

At the first stage of problematization, the participants had to understand those problems that impede them to put effectively their affairs in order in their lives. At the second stage or the optimization stage, they determined the goal for developing the optimal model of a flourishing community. The third stage is the search for resources that can be used for the realization of the created model and accomplishing the stated tasks. The fourth stage is an organizational design when the participants coordinate the found solutions with the specific conditions answering on the question who exactly and how he/she has to introduce the created model, propositions, and corrections.

The efficacy of the socio-psychological training and imitation game was verified by the interviewing data that were collected before and after classes and the subjective reflections and impressions of participants that they expressed during the questionnaire completion. According to the interviewing data, one significant change was found that freedom became more appreciated (56\% after the training) compared to $16 \%$ before the

\footnotetext{
29 Бирштейн М.М. Советские деловые игры 30-х годов м проблемы развития современной производственной деловой игры // Деловые игры и их программное обеспечение: Материалы конф. М.: ЦЭМИ АН СССР, 1976. С. 194-222.

${ }^{30}$ Вербицкий А.А. Деловая игра как метод активного обучения // «Совр. высш. школа». - 1982. № 3. C. $129-141$.

${ }_{31}$ Жуков Р.Ф. Исследлвание операций в деловых играх. - Л.: ИПК СП, 1980. 84 с.

32 Щедровицкий П.Г. К анализу топики организационно-деятельностных игр. - М.: ВНИСИ, 1987. $-43 \mathrm{c.}$

${ }^{33}$ Иваненко Л.Н. Имитационные игры в условиях массового эксперимента (принципы и практика) // Кибернетика. - 1982. № 4. С. 122-125.

34 Панфілова А.П. Игротехнический менеджмент. Интерактивные технологии для обучения и организационного развития персонала: Уч. пос. / А.П. Панфілова. - СПб:ИВЭСЭП, 2003. - 536 с.
} 
training $(p \leq 0.05)$. Several positive changes in the legal self-determination have been observed as a trend, for example, the value of the law and the trust in the law has been increased (from 22\% to 40\%) and (from 62\% to $70 \%$ ) accordingly. Also, the association of the law with the notion of civic duty has been strengthened (from $48 \%$ to $60 \%$ ) and in the same manner with justice (from 56\% to 60\%). The indicators of independence in solving life problems became more evident. In the control group, there were no apparent changes. Positive changes have been observed in the civic consciousness of the school students: the number of those, who are proud to be the citizens of Ukraine, grew (from $41 \%$ to $67 \%$ ), also the number of those, who chose Ukraine as a country of residence, increased (from $48 \%$ to $68 \%$ ), (in both cases $\mathrm{p} \leq 0.05$ ).

Some special results were obtained that reflect the positive changes in the subjects' legal self-determination: the basal trust in people and society has been strengthened; the importance of such values as "freedom", "law" and "trust" for moral and legal guidelines has been increased; an awareness of the role of law in public life has been deepened.

\section{CONCLUSIONS}

The legal self-determination of persons with low economic status and different levels of psychological gravity toward poverty is performed in the formation process of the cognitive, affective and behavioral components of the legal consciousness. In the process of the legal self-determination, the essence of the legal norms of society is realized. During this process one perceives the legal phenomena, the representations (cognitive component), feelings that reflect the attitude of the people and social communities to the existed or desired legal reality plus to the behavior of people in the legal sphere (affective component). Equally, the formation of a program of the purposeful and law-abiding activities (the behavioral component) is happening.

It has been determined that those, who subjectively identify themselves with the poor, defenseless, losers, more often excuse themselves for the unlawful inclination, individualism, and destructive emotions. To the large degree that causes the illegal behavior of the individual and also the growth of the resistance to the legal system in society. Such attitudes as fatal hopelessness without any prospects, dependence, and state of being oppressed with low motivation to work and 
achievements, inability to plan are inherent and predominant to them. Their desire to change the surrounding world, the sphere of social relationships is also caused by distorted, false interest. It can be contrary to the ideals, values, and goals of society, and in the contradiction between social and personal interests. In general, the poverty functions as a factor of the human rights violation. The poverty comes out in a form of important precondition for the deformation of a person's legal consciousness; it is "a social primitivism of social thought".

The construct of moral and legal self-consciousness of persons with a certain degree of psychological attraction to the poverty is determined, and components of which are the following: motivational-value, cognitive and reflexive components. In the results of these studies, it has been concluded that violations or "defects" of the legal consciousness are generated by the real-life socio-economic conditions in which the legal socialization goes on.

General efforts are important when they are directed at the development of a personal resource attitude to all kinds of circumstances and situations especially in positions of uncertainty. The resource should be understood as a personal ability to make optimal use of the internal potencies, the ability to mobilize them at any time, and the ability to efficiently operate them based on the opened possibility for usage also external resources. Any kind of situation either internal or external consists of conditions and means. The resource attitude to the situation allows us to consider any conditions as a means for usage.

The application of socio-psychological means and methods for a correctional influence provides the optimization of the legal consciousness and the process of the legal self-determination of persons with a shortage of economic resources and representatives of the impoverished social groups.

\section{SUMMARY}

The publication (in the section) deals with the socio-psychological peculiarities of the legal consciousness and the legal self-determination of the social group' representatives that have a low economic status in the conditions of current economic, political and legal transformation. The part of these social categories is characterized by the deformation of the legal consciousness, the distorted legal self-determination, the false selfregulation, and the distrust to the state legal institutions, civil rights, and freedoms. 
The socio-psychological factors of the legal self-determination are established. Those components that caused the distortion of the legal socialization and the system of self-regulation of a person are determined. The role of subjective factors of psychological gravity toward poverty is ascertained. It is determined that "defects" of the legal consciousness are generated by real-life socio-economic conditions in which legal socialization goes on.

The research demonstrates that for solving the addressed issues it is important to use correctional, developmental, and informative methods for optimizing the process of the legal self-determination of social groups' representatives that are poor, for development of the resource attitude of the person to different conditions and circumstances, situations of uncertainty, and the ability to apply the effective coping strategies.

\section{REFERENCES}

1. Бирштейн M.M. Советские деловые игры 30-х годов м проблемы развития современной производственной деловой игры // Деловые игры и их программное обеспечение: Материалы конф. М.: ЦЭМИ АН СССР, 1976. С. 194-222.

2. Васютинський В.О. Стиль життя як соціально-психологічна характеристика культури бідності / Васютинський В.О. // Наук. студії із соц. та політ. психології: Зб. статей / НАПН України, Ін-т соц. та політ. психології. - К., 2012. - Вип. 30 (33). - С. 19-32.

3. Ведерников Ю.А. Теорія держави та права : навч. посіб. / Ю.А. Ведерніков, В.С. Грекул. - К. : Центр навч. л-ри, 2005. - 224 с.

4. Вербицкий А.А. Деловая игра как метод активного обучения // «Совр. высш. школа». - 1982. № 3. С. 129-141.

5. Гилинский Я. Девиантология: социология преступности наркотизма, проституции, самоубийств и других «отклонений» / Я. Гилинский. Девиантология. - СПб.: Издательство «Юридический центр Пресс», 2004. - 520 с.

6. Гулевич О.А., Голынчик Е.О. Правосознание и правовая социализация. Аналитический обзор / О.А. Гулевич, Е.О. Голынчик. «Психология». Москва: Международное общество им. Л.С. Выготского. $-2003 .-270$ с.

7. Жуков Р. Ф. Исследлвание операций в деловых играх. - Л.: ИПК СП, 1980. 84 с. 
8. Иваненко Л. Н. Имитационные игры в условиях массового эксперимента (принципы и практика) // Кибернетика. - 1982. № 4. C. $122-125$.

9. Ильин И.А. О сущности правосознания / Теория права и государ-

ства / И.А. Ильин. - Моск. гос. ун-т им. М.В. Ломоносова. Юрид. фак. - Москва: Зерцало: Система Гарант, 2003. - 398 с.

10. Каліна Н.Ф. и др. Лики ментальности и поле политики: Монография / Н.Ф. Калина, Е.В. Черный, А.Д. Шоркин - К. : Агропромвидав України, 1999. - 184 с., - Библиогр.: С. 167-171.

11. Моросанова В.И. Опросник «Стиль саморегуляции поведения» / В.И. Моросанова (ССПМ): Руководство // М.: КогитоЦентр, 2004. - 44 с.

12. Муздыбаев К. Переживание бедности как социальной неудачи: атрибуция ответственности, стратегии совладания и индикаторы депривации / К. Муздыбаев // Социологический журнал. - 2000. - № 3/4. - С. 36.

13. Панфилова А.П. Игротехнический менеджмент. Интерактивные технологии для обучения и организационного развития персонала: Уч. пос. / А.П. Панфілова. - СПб:ИВЭСЭП, 2003. $-536 \mathrm{c}$.

14. Петражицкий Л.И. Теория права и государства в связи с теорией нравственности / Л.И. Петражицкий. - СПб.: Издательство «Лань», 2000. - 608 с.

15. Петров В.Р. Деформация правосознания граждан России (Проблемы теории и практики): Дис. ...канд. юрид. наук: 12.00.01 M. : РГБ, 2002 [Электронный pecypc: http://diss.rsl.ru/diss/02/0002/ 020002597.pdf ]

16. Петровская Т. Соціально-психологічні фактори економічної поведінки / Петровская Т. // Соціальна психологія. - 2004. - № 4(6). C. $23-35$.

17. Фетискин Н.П. Социально-психологическая диагностика развития личности и малых групп / Фетискин Н.П., Козлов В.В., Мануйлов Г.М. М.: Изд-во Ин-та Психотерапии, 2002. - 490 с. C. 193-197.

18. Хоріна О.І. Дестуктивні моделі міжособових стосунків підлітків. Наукові студії із соціальної та політичної психології: 
3б. Статей / АПН України, Інститут соціальної та політичної психології; Редкол.: С.Д. Максименко, М.М. Слюсаревський та ін.К.: Міленіум, 2008. - Вип. 19 (22). - С. 111-123.

19. Щедровицкий П.Г. К анализу топики организационнодеятельностных игр. - М.: ВНИСИ, 1987. 43 с.

Information about the author: Bielavina T. I. $\mathrm{PhD}$ in Psychology, Associate Professor at the Department of Psychology and Pedagogy of the Scientific and Humanitarian Institute of the V. I. Vernadsky Taurida National University 


\section{SOCIO-PSYCHOLOGICAL FACTORS OF PERSONAL GROWTH IN FAMILY CONDITIONS}

\section{Bila I. N.}

\section{INTRODUCTION}

The first and main "school" of socialization, social adaptation of the individual is a family. The family is a microsystem of society, which acts as the main agent of the influence on the personality that promotes knowledge and determines one or another of its qualities and characteristics. All components of the imdividual's structure, his abilities (motivationally-volitional, personality-value, operational-activity, cognitive-creative) can develop successfully only if there is a developing space, in particular, a family.

According to E. Bern, human destiny is largely driven by "parent programming, scripting" - the formation of a scenario, a plan of life in childhood under the influence of parents. After all, children tend to copy the behavior of those with whom they are in the closest contact. It is partly a deliberate attempt to behave in the same way as behaving meaningful adults, partly unconscious imitation, which is one aspect of identification with another. In this regard, it is important to note that children learn from their parents by certain ways of behavior, not only by mastering the rules that they directly report, but also by observing the model (examples) of behavior existing in the parent's relationship.

Parental love is a huge and irreplaceable source of spiritual development of the child, emotions, moral qualities, positive perception of the world, self-confidence; condition and inexhaustible source of sensitivity, care, respect for people. Communication in an atmosphere of intimacy, love, trust, care for each other has a strong influence on the child's psyche and further provides a wide area for the emotional experiences of the child, the realization of his needs, satisfaction of interests, and thus become for him the true school of social relations and the arena of self-realization. A child who has not received parental love grows hostile, angry, stubborn to the experiences of other people, brave, unproductive in a group of peers, sometimes - closed, too shy and uncertain. 
Messengers, which parents repeat repeatedly, are captured in subconscious ordinances and determine future value orientations, abilities. Communicating with adults who bring up a child is a source for him, not comparable to anything else bright, personally addressed to his influences, stimuli and patterns. It dismantles the axiomatic nature of the thesis of L.S. Vyhotsky that all higher mental functions of a person are primarily formed as external, that is, those in the implementation of which involves not only one, but at least two entities. And only gradually they become internal, turning from "interpsychic" into "intrapsychic". The development of the views of L.S. Vyhotsky led to the creation of an original concept of child development, in which the development of the child is understood as the process of children's appropriation of the socio-historical experience gained by previous generations of mankind (O.M. Zaporozhets', O.M. Leontiev, D.B. Elkonin) Proceeding from this, the promising way of forming personal reference points that determine the vital "trajectory", the vector of personality development is family interaction, communication in the family, which declares the democratic style of education, encouragement of activity, curiosity, and creativity of the child.

In this case, it is important that the strengthening of the educational potential of adults, the positive development of mutual influence in the family, which manifests itself in the growth of the level of pedagogical literacy of parents and affects the development, behavior of the child, its successful social adaptation.

\section{Family-centeredness in the development of the child's personality}

The child born to nature, endowed with the possibility of individual development in the social and cultural context of the era. The main characteristic of the such context is the concept of the social situation of development is developed by L.S. Vyhotsky. It is based on the child's experience of the environment of his residence and himself in this environment. If these experiences are positive, the environment has a developmental effect and in it is possible implementation and development of abilities of the child.

In the effective contact of the child with the surrounding world, in the process of gradual assimilation of the achievements of the previous historical development of mankind, carried out in the course of education, are transformed into diverse and advanced abilities (L.S. Vyhotsky, 
V.V. Davydov, H.S. Kostiuk , B.M. Teplov, S.L. Rubinshein, etc.). In a developing educational environment, the space of social interaction, the child finds incentives for self-education and self-development precisely at the initial stage of ontogenesis, which is crucial for the formation of personality, the formation of abilities. After all, in the preschool age, the person "is produced" (V.V. Davydov) is precisely in the creation of such an environment that would provide the child with developmental interaction, mastering the social space of human relationships, the special role of which is given to the "adult child" community.

As is known, in 1912 in Kyiv I.O. Sikorsky was created the world's first Institute of Child Psychology. Observation of development in early childhood made it possible for Sikorsky I.O. to conclude that "the numerous irregularities in the character of man and in his abilities are beginning in the early days, in the first months and years of life, and lead to persistent features of the mental composition of a future adult. Such disadvantages, which were considered congenital, and therefore it was considered that it is impossible to eliminate them, in the opinion of the professor, are accessible to the medical and pedagogical influence"1.

These findings have become the impetus for other studies in the field of children's, social psychology, family psychology. Thus, in particular, the problem of family education is devoted to a whole range of works and researches of native and foreign scholars (D. Baumring, E. Bern, P.P. Blonsky, V.M. Drujynin, S.O. Ladyvir, M.I. Lisin, P.F. Lesgaft, A.E Lichko, Dzh. Medina, V. Satir, A.S. Spivakovs'ka, V.O. Sukhomlyns'ky, E.H. Eyedemiller, T.M. Yablons'ka, etc. Psychologists have revealed psychological peculiarities relationships in the family, described the child-parents relationship.

The main thesis in the most studies of the field of social work in the family, family psychology can be formulated as such: "The nature of the relationship in the family affects the development of the child, his later life". In general, the negative factors of family education are: inadequate influence of the factors of the material order: the priority of material wellbeing over the realization of the spiritual needs of the child; lack of spirituality of parents, lack of desire for the spiritual development of

\footnotetext{
Ponomareva-Semenova R.A. Methodological aspect of developing a psychological model of an extraordinary personality // Current problems of psychology: Volume 6. Gifted personality: search, development, help. (collection of scientific works). / Under the editorship of S.D. Maximenko. - K. "BONA MENTE", 2002. Vip. 3. (Part 1) - P. 226-236.
} 
children; authoritarianism or parental liberalism; immoral style and tone of family relationships; absence in the family of a normal psychological climate and pedagogical culture of communication; illiteracy in the psychological and pedagogical relation (lack of purposefulness of education, unprincipled, contradictory in the application of methods of education, physical punishment, infliction of children of severe moral suffering), etc. For children deprived of favorable family conditions, strong and unequivocal evidence of parental love, confidential communication, psychophysiological and psychosomatic disorders, neurotic disorders, difficulties in communication and mental activity are much more often observed. Communication creates a feeling of emotional well-being, warmth and comfort in a new and unfamiliar world. These feelings are like fertile rains that irrigate the delicate shoots of the first knowledge and skills of the child. Studies show that in conditions of "drought" of human feelings, in the absence of communication, these sprouts develop poorly, and sometimes completely fade ${ }^{2}$.

Thus, as a result of the "environmental" research program, it was found out by V.M. Drujynin that the family environment develops the creative abilities (ability to intellectual creativity), non-verbal intelligence and partial abilities (memory, attention, sensomotorics). In the work of O.L. Hryhorenko and B.I. Kochubey, it is proved that the magnitude of the genetic predisposition of most personal qualities (excluding temperament) is significantly downward from the indicators of imitation of general and special abilities, and the level of development of verbal and non-verbal creativity (general creative ability) depends from the breadth of the circle of communication and the presence in the family of a democratic style of education ${ }^{3}$.

It is worth noting that the style of education is understood as a certain strategy of education, as a combination of different behaviors of parents, which in different situations and at different times will manifest itself to a greater or lesser extent. This approach allows you to build a peculiar profile of parenting behavior that reflects the most characteristic style of education, both in the individual case for a particular parent, and for a group of parents of children of a certain age.

\footnotetext{
${ }^{2}$ Subbotsky Ye.V. The child opens the world: Kn. for the child's teacher. the garden / E.V. Subbotsky. - M. : Enlightenment. - $1991-207$ p.

${ }^{3}$ Druzhynin V.N. Psychological abilities / V.N. Druzhynin. - St. Petersburg: Publishing House "Peter", 2000. - 368 p. : (Series of "Masters of Psychology").
} 
Nowadays, scientists have proposed different classifications of childparents relationships, styles of education. In our opinion, Diana Baumrind's classificstion of the parenting styles are based on two pillars of education, each of which is on the continuum: sensitivity is the degree of parents' response to their children with support, warmth and compassion. and demanding that takes into account the degree of parents' desire to control the behavior of the child. Taking into account these characteristics creates four verified large-scale study of the styles of upbringing children. Namely:

Authoritarian (over hard) - insensitivity plus demanding. For these parents, it is very important to establish authority over their children, and the children of these parents often fear them. They do not try to explain their rules and are completely devoid of warmth and benevolence.

Covetous (too soft) - sensitivity plus non-necessity. These parents love their children very much, but they are not able to establish and enforce the rules. Subsequently, they avoid confrontations and occasionally demand compliance with family rules. These parents are often confused with the task of bringing up children.

Neglect (too detached) - insensitivity plus indifference. These parents take little care of their children and do not take part in their daily lives, providing only basic care.

Authority (suitable) - sensitivity plus demanding. These parents are demanding, but they care a lot about their children. They explain their rules and encourage them to respond to them, encourage self-reliance, but ensure that children adhere to family values. These parents are usually inclined to have good communication skills with their children ${ }^{4}$.

On the decisive significance of family education in the development of personality, from the birth of a child to her admission to school, also emphasized P.F. Leshaft, and proposed his classification of the parents' position in relation to children:

27. Parents do not pay attention to children, humiliate, ignore them. In such families, children often grow up hypocritical, false, they often have a low intelligence or a delay in mental development.

28. Parents constantly admire their children, consider them a model of perfection. Children often grow selfish, superficial, self-confident.

\footnotetext{
${ }^{4}$ Medina John. Rules for the Development of the Child's Brain / John Medina. - K. : Our format. 2015.
} 
29. Harmonious relationships built on love and respect. Children are distinguished by kindness and depth of thinking, aspiration for knowledge.

30. Parents are constantly dissatisfied with the child, criticize and condemn her. The child grows an1noyingly, emotionally unstable.

31. Parents excessively corrupting and protecting the child, it grows lazy, socially immature.

32. Parents whose behavior is affected by financial difficulties. Their children grow up with a pessimistic attitude towards the outside world ${ }^{5}$.

Incorrect parenting, improper parenting provokes the appearance of negative traits of character, its accentuation. According to scientists (A.E. Lichko, K. Leonhard, V.V. Yustyts'ky, E.H. Eyedemiller), there is a pattern between the type of accentuation of nature and the kind of incorrect education, from the position of the styles of family upbringing. As regards the thought of children about the style parenting, then research has shown that children generally like the inductive style of correction, seasoned with a periodic demonstration of strength. Children between the ages of four and nine, as opposed to adolescents, hate permissiveness. Parents whose rules are derived from sensitive perception, and motivations are constantly explained, ultimately perceived as smart and just, and not capricious and despotic, they are more likely to receive obedience from their children instead of loyal resistance ${ }^{6}$.

The experiment of A. Bandura "Lessons of Clown Bobo" proved to be valuable, in which he showed the role of learning through observation and proved that children (and adults) learn a lot by observing the behavior of others. This can also be a positive phenomenon. For example, Mexican "soap opera", whose heroes are fond of books, and then ask viewers to enroll in the reader's circle, to increase the level of readability throughout the country. The discovery of A. Bandura became an extraordinary weapon of mass training and reaffirmed the idea of the social situation of development.

It is exactly family interaction, "mental stimulation" that occurs when communicating and co-operative activities of the child and adult is a decisive environmental factor in the development of children's intelligence. For example, the results of the study conducted by V.M. Drujynin showed that those who received experimental support from the emotional support better solved test tasks, and the presence or absence of

\footnotetext{
${ }^{5}$ Leshaft P.F. Family medicine peder / P.F. Leshaft. - Moscow: Pedagogics, $2014-224$ p.

${ }^{6}$ Medina John. Rules for the Development of the Child's Brain / John Medina. - K. : Our format. 2015.
} 
control over the behavior of the child does not significantly affect the measurement of intelligence. That is, not cognitive-behavioral control, but emotional support, the creation of a certain emotional environment affects the outcome of mental activity of the child. In the absence of control of behavior and emotional support, smart children begin to fear failure. On the contrary, with a high control of behavior and emotional support (dominant hyperprotection), low-intellectual children develop motivation for success. With the preservation of emotional support and the lack of rigorous control on the part of the adult raises intellectual productivity ${ }^{7}$.

All this corresponds to the ideas of L.S. Vyhotsky about the "zone of immediate development": any supportive intervention of an adult improves the result of the task. In general, the influence of communication on the mental development of the child occurs due to: 1) the favorable "objective" qualities of the adult, which is combined with its properties as the subject of communication; 2) enrichment of the adult experience of children; 3 ) direct setting of adults tasks that require the child to master new knowledge, skills and abilities; 4) the supporting effect of opinions and assessments of an adult; 5) opportunities for the child to draw in communicating patterns of actions and actions of adults; 6) favorable conditions for children to disclose their creative, original beginning ${ }^{8}$.

According to M.I. Lisin, the three groups of facts prove the decisive role of communication in the general mental development of the child, in particular: 1) the study of children, "Mowgli" (children who have grown in isolation from society have a deep and irreversible underdevelopment), 2) study of the nature and causes of hospitalization (deviations associated with the lack of maternal care, in particular, children who are brought up in orphanages), and 3) the direct manifestation of the influence of communication on mental development in forming experiments.

Confirmation is also the result of the study, obtained by Skills and his staff in the 1930's in one of the boarding houses for mentally retarded children in Iowa. In total, the group consisted of $25 \mathrm{kids}$, these children all the time lay in their beds and were separated from each other by curtains. It has been noticed that children who grew up in such conditions, as a rule, never reach the normal level of intellectual adaptation, the majority remains in clinics for mentally disabled. Skills took 13 children and placed

\footnotetext{
${ }^{7}$ Druzhynin V.N. Psychological studies / V. Druzhynin. - Moscow: “KSP”, 1996. - 160 p.

${ }^{8}$ Lisina M.I. Problems of ontogenesis of communication / M.I. Lisin // Scientific research. Institute of General and Pedagogical Psychology Acad. ped Sciences of the USSR. - Moscow: Pedagogics, 1986. - 144 p.
} 
in a mortgage for mentally disabled women. Women were very emotionally embraced by babies, looked after them, talked and caressed. Subsequently, children began to develop rapidly, their intellect reached norms, and practically all of them in the future became full members of society (four received higher education) ${ }^{9}$.

Communication, according to scientists, is just as necessary for the child as food. A kid who receives a good nutrition and good medical care but is deprived of constant contacts with adults develops not only mentally, but physically. It is noted that when children are brought up in a kindergarten, where the communication of a child with an adult is minimized, since one educator has more than 10 children, they are lagging behind their peers who are raised in the family, in intellectual and sensory-motor development [7]. It was found that for the survival and development of the child, it is necessary that they play with her, spoken several times a day. Human communication is vital to the child. Familiar family physician Virginia Satir recommends hugging a child several times a day, arguing that four hugs are needed for everyone just to survive, and for at least eight hugs a day ${ }^{10}$ !

It should also be emphasized that for the proper mental development of a small child, relations with the mother are of paramount importance (J. Boulby, R. Spitts, A. Freud and others). It is maternal love that gives the baby a sense of security, contributes to the development of the image of themselves and socialization. Lack of communication with her, endangers the child's life, impedes her physical and mental development. Thus, I.V. Dubrovina, A.H. Ruzskaya characterizing the portrait of a person formed in a child who was born from birth in conditions of maternal deprivation, points to her: an intellectual lag; the inability to enter into meaningful relationships with other people; lethargy of emotional reactions; aggressiveness; self-doubt and so on. In children who have experienced maternal deprivation, confidence in the world can only arise through emotional warmth of constant maternal care.

It is obvious that the influence of his father significantly affects the formation and development of the child's personality. In the process of education, the father instills important qualities for his children. For a boy, this is a man's dignity, a chivalrous attitude to a woman, the ability to take responsibility, ability to work. Father is an example for his son for

\footnotetext{
${ }^{9}$ Druzhynin V.N. Psychological studies / V. Druzhynin. - Moscow: "KSP”, 1996. - 160 p.

${ }^{10}$ Hippenreiter Y.B. Communicate with the child. How? / Y.B. Hippenreiter, - Moscow: CheRo, 2001.240 p.: il.
} 
imitation and greatly affects the formation of sexual identity. Boys copy the behavior and style of parenting their own, they have a certain scenario of their future life.

It is worth mentioning the results of the research of prenatal psychology. According to E. Bern, the role of the child can also be influenced by the situation of conception, he suggested that the situation be called "the embryonic setting" and recommended to analyze the circumstances of the birth of life. The attitude of parents to the process of conception also reflects on their attitude towards the child. If conception has occurred erroneously, it is likely that the attitude of the child will be appropriate. Based on his research, E. Bern concluded that there are "generic scenarios" that are formed up to five years. In his view, a person begins to live like a "loser" or "victor", grows "family pride" or "those who do not justify hope" $"$.

Similar conclusions were made by S. Hroff, proclaiming his concept of prenatal existence. He singled out four periods that are stored in the human subconscious, calling them basic prenatal matrices, each of which forms a strategy for the attitude toward the world to himself.

From the first minutes of the birth of a new life, parental love determines the life scenario, it is a huge and irreplaceable source of spiritual development of the child, emotions, moral qualities, positive perception of the world, self-confidence; condition and inexhaustible source of sensitivity, care, respect for other people in the future. Scientists emphasize that childhood, full of love, is enough for all the rest of life. A child who has not received parental love grows hostile, angry, stubborn to the experiences of other people, brave, unproductive in a group of peers, sometimes - closed, too shy and uncertain. A child who grew up in an atmosphere of excessive love, clutter, reverence and indulgence will soon develop the features of selfishness and egocentrism, of modesty, promiscuity, indifference and hypocrisy. If the family has no harmony of feelings, if the child is generally exposed to the effects of the immoral atmosphere, emotionally negative manifestations towards the child, then in such families the development of the child becomes more complicated, family education becomes an adverse factor in the formation of the child's personality, complicates the development of abilities child ${ }^{12}$.

\footnotetext{
${ }^{11}$ Bern E. Games in which people play // E. Bern - Exmo, 2003. - 576 p.

12 Schneider L.B. Family: Looking Back / L.B. Schneider. - SPb. : Peter, 2013. - 368 pp .: Il. - (Series of "Masters of Psychology").
} 
Well-known psychotherapist V.I. Harbuzov warns against the use of wrong education:

1. A-type education (rejection, emotional rejection) - the rejection of the individual characteristics of the child, combined with strict control, with the imperative imposing on her the only correct type of behavior. The type of upbringing A can be combined with lack of control and even full complacency.

2. B-type education (hyper-socializing) is expressed in the anxious and distrustful concentration of parents on the health status of the child, her social status among comrades, and especially in school, expecting success in education and future professional activities.

3. C-type education (egcentric) - cultivating the attention of all family members on the child, sometimes to the detriment of other children or family members.

An interesting classification of deviations in the styles of family education (which correlates the peculiarities of the formation of the personality of children and the styles of family education) offer A.E. Lichko and E.H. Eyedemiller:

Hypoprotection is characterized by a lack of burn and control. The child remains unattended. The non-inclusion of the child in the life of the family leads to an antisocial behavior because of the dissatisfaction with the need for love and recognition.

Dominant hyperprotection is manifested in increased, intense attention and care, excessive welfare and behavioral control, slips, bans and limitations. The child is not accustomed to autonomy and responsibility. This leads either to the reaction of emancipation, or to non-initiative, the inability to stand up for oneself.

Hyperprotection, the so-called upbringing of the "family idol". Parents seek to free the child from the slightest difficulty, indulge her desire, overwhelmingly adore and admire her successes and demand the same passion from others. The result of this upbringing is manifested in a high level of aspiration, aspiration for leadership, which can be combined with insufficient stubbornness and reliance on their strengths.

Emotional rejection - the child is burdened, her needs are ignored. Sometimes they are cruelly treated with her. Parents consider the child a burden and show general dissatisfaction with her. Often there is a hidden emotional exclusion: parents tend to veil the real attitude towards the child 
with increased care and attention to it. Such a style of education has the most negative impact on the development of the child (loss of love, loss of personality, love for "themselves").

It has been established that only a small part of the parent community is able to ensure the harmonious development of the child's individuality $(14.5 \%)$. In the majority of the same families, there was a tendency toward a partial parenting style (74.5\%), in which only the child's needs are partially met, their individual differences are not fully taken into account, and care for the development of defining properties for individuality manifests itself episodically. In a significant number of families, the focus was on the disharmonious development of the child's individuality $(11 \%)^{13}$.

This type of family includes families living below the poverty line. Poverty, according to T.V. Hovorun, affects families, and their lives, planning life on "daily stresses", which correlate with many negative manifestations-lag, in the ability to learn in the first place. The lack of cognitive skills has been documented in psychological studies in children from poor families since 3-4 years. The economic problems of parents from poor families affect the attitude towards their own children: they are either authoritarian, more annoyed with the needs of their care, aggressive in situations of expert examination of the conditions of development, much more adept at behaving the young, arrogant and punishing the slightest fault, do not even satisfy basic needs of the child. Or much more often, choosing ignorant, ignoring the style of education, indifferent not only to any needs and interests of children, but also to their illnesses or successes, manipulate them, do not concern themselves with behavior, nutrition, dress, well-being and, even, a long absence children at home. Both those who are incapable of normal care and care of children, empathy communication with them, satisfaction of both their biological and social needs, indifferent to their vital activity in general. They are more likely to exhibit negative emotions about the world around them, their neighbors, teachers, and more often they oppress children by applying their physical and mental punishment, which in aggregate can not but affect the asthenic or giperastenicheskih mental states of children.

Consequently, an economic factor, along with others, in the first place predetermines the unfavorable psychological climate of the family,

\footnotetext{
${ }^{13}$ Hovorun T.V. Basic preconditions for the emergence and re-socialization of children and young people at risk groups / T.V. Hovorun // ScienceRise. - 2015. - No. 8 (1). - P. 84-89. - Access mode: http://nbuv.gov.ua/ UJRN/texc_2015_8(1)15
} 
pathological styles of family upbringing. The experience of relative economic deprivation and frustration plays the role of a trigger mechanism, which begins to spread its destructive effect on the birth and development of abilities and all those personal components that determine the norm of mental development. It becomes sufficiently significant in causing the risk of personal development primarily to children of immigrant families, refugees, single, large families, national minorities, and minors.

The connection between the living conditions and the upbringing in the family and the type of personality of the child was also revealed in the researches of N.I. Nepomnyaschaya. According to the results, in the families of children with a valuable background of real-life functioning, the lowest type of relations, "I am different", one of the leading values is often considered material well-being, adjusted life, as a rule, reigns the cult of real, practical, and not personality relations. Therefore, the child, its achievement parents evaluate in terms of not only her personality, but the result achieved. The prevalence of close negative assessments that accumulates the experience of failures leads to the fact that many children in this group lack independence, they are unsure of themselves, often feel fear, show negativism, conflict, inadequate perception of behavior and attitude towards themselves from other children ${ }^{14}$.

In families with universal values (but these children, unfortunately, they form a minority), children are raised with the highest type of relations "I am different", with a high level of development of the ability to "be myself and another one" with high indicators of overcoming the limited perceptions of the world and ourselves, the development of consciousness and activity. Many tales tell children in such families, at home they play with them a lot, games and toys change from time to time, and children often invent their new games themselves. Characteristic for these families is also the openness of the family to people, different interests, diverse and new affairs, they have family traditions, produced a home newspaper, etc. All this forms in children a desire for an interesting (in all spheres), new, perfection, creative attitude to any business.

\footnotetext{
${ }^{14}$ Nepomnyaschaya N.I. Formation of the personality of the child 6-7 years / N.I. Nepomniachaya // Scientific research. Institute of General and Pedagogical Psychology Acad. ped Sciences of the USSR. Moscow: Pedagogics, 1992. - 180 p.
} 
As a rule, in families, which distinguishes openness to various interests, affairs, people, the diversity of forms and content of communication with the child, the attention to other people, care for them, responsible and personal attitude to various activities and assessment through such an attitude of the child's personality, every kind of promotion of love for games, recognizes the high value of education, gifted children are brought up. Parents pay special attention to teaching their child, choosing for her books, manuals, educational games, etc. Children and parents combine common cognitive interests, on the basis of which there are stable friendly relations. Home, virtually obligatory feature of the family of any gifted child - unusually high attention to the child. Adult support leads to the consolidation of certain forms of behavior, the reaction of parents determines the further development of abilities and talents of children.

That is, family interaction, communication is through the formation of personal orientations that determine the vital "trajectory", a vector of development abilities. His construction stimulates the relationship between children and adults, joint games, walks, classes, reading fiction, and excursions with them in nature. In general, the promotion and support of aesthetic, moral needs contributes to the formation of a personality and value foundation for the development of abilities; the formation of volitional qualities and emotional processes, provides a motivationalvolitional aspect of the development of abilities.

The dynamics of the formation of all components of the development of abilities, the acquisition of cognitive, social experience, the stock of children's knowledge in the majority depends on how the parents provide the child with meaningful cognitive communication, support hobbies, interests of the child, offer various cognitive, developmental sources and incentives, create an educational, educational environment.

Only the family, father and mother, who are aware of all responsibility and significance of family interaction, are fully capable of providing the necessary conditions for a developing environment for the development of the child's personality and the flowering of her abilities. The family puts the foundations of personality, its future, formed motivational-volitional, cognitive-creative, personality-value and operational components of abilities. The family, where the child gets maternal care, the support of his father, where love and authoritative style of education reigns, a person is born and growing. 


\section{The basis of the formation of conscious paternity}

Formation of the person takes place in the presence of a favorable development environment, in the conditions of family education and partner interaction. The decisive factor in the development of a child is the presence of a meaningful adult in the immediate surroundings. In communication with adults and under their constant guidance and influence, the child is gradually mastering a variety of activities, skills, and developing his abilities. But, unfortunately, today one of the acute problems is the issue of the lack of formation in the youth of readiness for family life, the birth and upbringing of children as conscious, responsible parents.

Today, there is a typical problem of avoiding the traditional division of roles in the family, devaluation of family values and traditions, reducing the level of family stability, spreading orphanage, feminization, and other relevant phenomena in the field of family psychology, child-parent relationships. That is why the subject of psychological research focuses on the study of the problem of conscious (conscious), responsible fatherhood. "Fatherhood", as a social and pedagogical phenomenon, includes a set of paternal features, feelings, knowledge and skills of child development to ensure the formation of a healthy and mature person, starting with childhood. This phenomenon is the subject of interdisciplinary research, is studied within the framework of not only psychological, but also social, pedagogical and other sciences, which initiate the development of scientific approaches and measures of social and psychological patronage of a young family. Informational education of future and young parents, raising the level of psychological and pedagogical competence of specialists working with young people, as well as integration of services of social-pedagogical, psychological and specialized support of young families are an important prerequisite for family well-being and full-fledged development of childhood.

It is worth emphasizing that scientists consider conscious, responsible fatherhood as a socio-psychological phenomenon based on a certain system of knowledge, skills, skills, feelings, qualities that are realized in the responsible behavior of parents, aimed at the upbringing and development of the child, the formation of her harmonious personality. Conscious paternity is the highest level of parenting competence, which is characterized by a combination of cognitive (knowledge) and behavioral (skills, skills, actions) systems. In the context of the cognitive component, 
in the first place, parents must have knowledge of the laws of the age-old mental and physiological development of children, of parental functions, needs of the child; on the optimal organization of the child's life in the family; the specifics and conditions of the formation of abilities during childhood; to understand the values of family life and family upbringing. Valuable orientations are an important factor for the family, both at the level of interaction between the spouses, and at the level of interaction between parents with children. These include such values as love, health, healthy lifestyles, family and cultural-national traditions and customs. Parents should also have the knowledge and knowledge about problems, typical family education failures and ways to eliminate them. Such mistakes include: underestimation of a personal example of parents (parents translate values to children, but do not support their own behavior); assigning children the qualities they do not own or exaggerating them; incorrect behavior of individual parents in everyday life; inability to use methods of education, especially encouragement and punishment; removal of children from forced domestic work; the lack of unity of requirements in the parent's educational activities; absence of tact in relations with the child; revaluation by parents of their educational opportunities; application of physical punishment; quarrels of parents in the presence of children, etc.

Important in the structure of conscious fatherhood is the operational component, which implies the possession of certain skills for the successful implementation of conscious methods, techniques, forms of education, training and self-development, self-realization of the child's personality. This component can be realized in the ability to organize the lives of children, to diagnose their abilities, interests and inclinations, to encourage and develop them, creating favorable conditions for this. This is, in particular, the ability to constructively communicate and resolve conflicts; organization of family-friendly interaction, child's activity; construction and implementation of a unified system of values; the optimal psychological and pedagogical environment surrounding the child in the family; skills of humanistic upbringing of the child. Also valuable is the creative component that allows parents to creatively use their own knowledge and skills in educational activities, based on the conditions in their family, to build an event series, as well as to use advances in the field of pedagogy and psychology. 
At the advanced stage, parenthood includes parental values, attitudes and expectations, parental attitude, feelings, parental responsibility, parental responsibility, as well as the style of family upbringing, which involves observing the principles of family education, which are permeated with the humanistic idea of the highest value of the child, namely : children should grow up and be brought up in an atmosphere of benevolence, love and happiness; parents must understand and accept their child as it is, and promote the development of a better one; Educational influences must be based on age and individual characteristics; the dialectical unity of sincere, deep respect for personality and high demands on it should be the basis of family upbringing; the identity of the parents themselves - an ideal model for the imitation of children; education should be built on the basis of positive foundations in a growing person; all activities that are organized in the family for the development of the child must be built on the game; optimism and positive - the basis of style and tone of communication with children in the family.

Generally, conscious parenting is the interaction of parents or individuals who replace them, among themselves, with other family members, including children, which results in the creation of the most favorable conditions for the full, harmonious personal and social development of the child at all stages of her life. Conscious paternity based on family interaction, which activates cognitive, productive activity, supports interest and motivation to it, stimulates the development of the personality-value, cognitive-creative sphere is a necessary factor in the manifestation of abilities and the formation of the gifts of the child.

In this context, the negative factors of family education that hinder the formation, development of the child's personal potential are: the priority of material well-being over the realization of the spiritual needs of the child; lack of spirituality of parents, lack of desire for personal development of children; authoritarianism or liberalism; immoral style and tone of family relationships; absence in the family of a normal psychological climate and pedagogical culture of communication; illiteracy in the psychological and pedagogical relation (lack of purposefulness of education, unprincipled, contradictory in the application of methods of education, physical punishment, infliction of children of severe moral suffering), etc.

With the preventive and correctional purpose of forming a conscious, responsible parenthood, you can use a variety of activities: the development of information leaflets, monuments; conducting of seminars, 
trainings, round tables; organization of mutual support groups; the work of the "Telephone of Confidence" service, an advisory point; realization of programs, including classes with future, young parents. The main goal of all these measures is to popularize the idea of a responsible one. conscious paternity as an indispensable condition for the harmonious development of the child. The growth of the level of pedagogical literacy of parents increases the positive developmental interactions in the family, which affects the development, behavior of the child and promotes the growth of his abilities.

Thus, responsible, conscious parenting, which is a system of knowledge, skills, skills and experience in the field of child upbringing, willingness and ability of parents to responsibly solve vital problems for the family, is an important prerequisite for the development of personality in childhood.

\section{Program of socio-psychological support of paternity}

Nowadays, the problem of paternity is acute not only in terms of the demographic situation of fertility, but also in the context of the negative socio-psychological problems of the formation of a harmonious personality. Young parents who have become parents often do not realize all responsibility for their paternity duties, do not have a set of necessary competences in the field of paternity, become hostages of their own problems in raising children and family relationships.

Responsible, conscious paternity manifests itself in the general culture of the individual's parents, its qualitative characteristics, the degree of readiness for the upbringing of the future child. The opposite of conscious and responsible fatherhood is the phenomenon of deviant motherhood / parenthood, which is often accompanied by an aggressive attitude of the mother or father to the child. The program of "uselessness" destroys the child's psyche even in the fetal period and increases during the early childhood by careless, disrespectful attitudes. This once again proves the necessity of forming sense of conscious and responsible parenthood in modern youth.

We are convinced that during the planning period, the expectation of the child and her early childhood, the family needs professional social and psychological support, support aimed at creating a favorable psychological climate in the family to reveal the emotional, intellectual and social potential of the family as a whole, taking into account the individual and 
age characteristics of the child, the prevention of mental disorders and deviations in her behavior. And, paraphrasing Bismarck, we would remark that if today we do not "build" schools of fatherhood, then tomorrow we will have to build prisons.

All of the above has led us to develop a special program of psychological and pedagogical support for married couples aimed at the formation, prevention and correction of effective family interaction, the formation of a democratic style of family education, the community of "child-adult", a developing environment. The program indirectly declares the values of family and parenthood in human life; informs about the ethics and psychology of family life, effective parenting behavior; forms responsible attitude towards parental functions; develops dialogic communication skills; promotes self-realization and self-realization in the conditions of the family.

In addition to individual consultations, the program involves conducting a training course, which includes four courses: "Readiness for marital life", "ABC of family communication", "Understanding of one's own life", "Conscious parenthood". Each course includes a series of exercises, the sequence and duration of which is determined by the coach. An integral part of this curriculum and in fact every class is an exercise in which participants can share their thoughts and feelings, their successes and failures.

\section{Lesson 1. Readiness for married life}

Exercise "My Name"

Exercise is performed in a circle, each participant names his name and answers the question:

- Who and why gave you name?

- Do you like your name?

Exercise has a reflexive goal - participants turn to their past, recall the history of their name, which has roots in the family.

Exercise "Brainstorming"

Participants discuss the issues:

- What is the perfect family? motherhood?

- What factors influence the formation of parenthood and

It should be borne in mind that hierarchically all factors that influence the formation of family, parentage and maternity can be placed at the following levels: 1) level of society, 2) level of parent's family, 3) level of 
their own family and 4) level of specific personality. Society gives a person a model of paternity, which initiates the formation of paternity in each particular case, taking into account the peculiarities of the spouses, their value-motivational sphere and the experience gained in the parent's family.

\section{Exercise "Associative Chain"}

On the board, the leader divides the sheet into three columns with the names: "Family", "Parents", "Child".

Participants are asked to pick up one word association associated with these concepts and write in their workbook. Then alternate voice their associations to these concepts, and the presenter writes them in the corresponding column on the board, creating a kind of associative chains.

The host invites participants to select any of the named associations and combine them with the other, the most successful, in his opinion, from the proposed.

Subsequently, by grouping together, they work on defining each concept based on the corresponding associative chains. Then the groups present their definitions in a large circle.

Discussion Questions:

- Why it was necessary to determine the meaning of the concepts of "family", "child", "parents".

- Did assimilation words help to define the concepts?

Exercise "Myths and Reality"

Often young people who enter into marriage and those who are already married have a poor understanding of the family. The reasons for this can be diverse: the lack of a sample of normal relationships in the parent's family, social deprivation, indifference, selfishness, etc.

All turn out to be an example of their own lives in relation to the "myths of married life" and discuss its "myths and reality".

Questions that will encourage listeners to share their thoughts.

- What are your hopes and expectations about the role of husband or wife and how do they come about?

- What model of marital life have you observed in your parents' family, what would you like and do not want to move to your own?

- How do you spend time in a family circle?

Exercise "Family Responsibilities".

Participants are offered a list of possible family responsibilities that need to be shared between husband and wife. 
Approximate list of responsibilities: washing dishes, washing a car, home repairs, repairing clothes, gardening / gardening, home cleaning, buying food, cooking, washing, making money, making purchasing decisions, caring for a child, raising children, planning leave, home accounting, etc.

Exercise "On the threshold of the family".

The exercise is aimed at actualizing possible conflicts that may arise when creating your own family. Each participant receives a situation card / task and announces his version of the solution.

List of approximate questions:

- How would you treat jealousy from your loved one?

- Who will take care of the child, for which help you wait?

- Does the father have the right to an equal (or decisive) vote in matters of raising a child?

-What way to use for saving money?

- How will you react if your wife does not cook tasty and monotonous?

- Can relatives interfere with your relationships and lifestyles?

- Can friends stay for you to sleep?

- How will you treat the bad habits of your halves?

Exercise "Tree of Family Values"

In this exercise, it is necessary to receive the procurement of "Trees of Family Values" and a list of possible family values and to diagnose them. In the root system to put the most important values from which you do not want to refuse under any conditions; in a trunk - important, but from which in some cases it is possible to refuse; in the crown - desirable but not obligatory values.

List of family values: respect, care, sincerity, kindness, patience, courage, diligence, financial security, health, love, mutual understanding, common goals, family traditions, hobbies, education, communication between generations, etc.

Exercise "Family History"

Participants talk about an item that has long been stored in their family and is its relic and pride. It could be a photo of grandfather, grandmother, inherited book, old paper or reward. Think you leave your children inherited?

Exercise "Ingredients for strengthening the family"

All participants write an idea that, in their opinion, promotes the strengthening of the family and the establishment of relationships with 
children, attaching it to the board. Then the presenter alternates with the idea and collects the analysis together.

\section{Exercise "Candle"}

The participants become in a circle, transmit a candle in a circle and speak warm words, compliments, gratitude to each other.

\section{Lesson 2. Alphabet of family communication}

Exercise "Association"

Participants are invited to continue the sentence:

1) If the family is a building, then it ... (fortress, tent, hostel, ...);

2) If the family is a color then it ...;

3) If the family is a music, then it (the play on the violin, metal, cacophony, ...);

4) If the family is a geometric figure, then it ...;

5) If the family is the name of the film, then it ...;

6) If the family is a mood, then it ... (stress, calm, ...).

Exercise "Maps"

Each participant picks out a deck of cards that depicts scenes from his family life and tells which scenes he is enjoying, and which ones he does not want to repeat.

Exercise "Comparison of Values"

Participants list: a) the most significant values of their partner; b) their significant values.

Subsequently, familiarize them with their partners, compare their values with the vision of their partner. What would you like to change in these lists?

\section{Exercise "I-utterance"}

Young people write on a blank sheet for a flipchart notebook: "I'm worried", and they continue sentences several times ...

This way helps to relieve tension in the situation and encourages another person to pause and listen. In order to properly use the "Imessage", we need to know what we feel, and then simply and honestly say about it.

Gradually, parents learn to change "You-message" to "I-message": train the skills and try to turn "You-message" to "I-message" on specific examples.

Exercise "You are the most ..."

Participants in pairs in turn call the positive qualities of each other, starting with a sentence from the words: "You are the most ...". 


\section{Exercise "Request and Requirements"}

Sit alongside a partner. Ask him about anything in a demanding form. What do you feel when you ask and find out what your partner feels at the same time.

Now ask for something, expressing your feelings (recalling merits, emphasizing authority, using compliments), asking and listening. What does the other feel?

\section{Exercise "Your Exit"}

Each member of the group speaks to the group twice (it can be a poem, song, dance) - once the group demonstrates its inattention (sit back, talking, yawning, etc.), and the next time - active attention and interest. Speaker, speaking, compares his feelings.

Exercise "Ask"

The group is divided into pairs, in the hands of one of them a toy, which he can give only if he wants to. The one who asks must use all the different ways of influence: orders, persuasion, persuasion.

In the discussion, it's important to find out: What is the most effective in communicating? How to communicate in order to achieve its goal?

Exercise "Learn to listen"

In a circle, each participant has to repeat what the participant has said on the right, and add something from himself. The third one should repeat the phrase of the first, the second participant and add something to his own, etc.

\section{Exercise "Drawing by instruction"}

The pair sits back to each other. One of them receives a card depicting geometric figures in different combinations. His task is to instruct the other partner so that he can reproduce the image of the card. The one who draws: a) can ask clarifying questions; b) can not communicate with a partner.

Exercise "Family Contract"

Participants record points that determine, in their opinion, the rights and responsibilities of partners in their family. The discussion is based on the example of one family.

\section{Lesson 3. Understanding your own life}

Exercise "About Me"

Participants are asked to find a partner and answer questions (a list of questions, written on a sheet of notebook for flipchart):

- What can you say about yourself when you were five years old? 
- How did your parents name you?

-What do you think your parents would describe you at that age?

-What childhood memories are most vivid?

-What was your favorite toy and game?

- What kind of movie hero, fairy tale or heroine can you identify yourself? Why?

- What is your favorite book? What does it mean for you?

- Which of your family members are you most alike to? Why?

- What of your own childhood would you like to happen in the life of your child? (Remember and tell about the best moments of your childhood).

These questions and other questions can be discussed in small groups as well.

Exercise "Autobiographical essay"

Participants sit in a circle and orally present their autobiographical essays; share important life experiences, accumulated from childhood till now. This experience should be important in the sense that it has a strong influence on the formation of each individual.

Exercise "If I Were a Child..."

Imagine what it would be if you for a moment became a child ...

What would you like to do in this situation? What activity would you do with whom you would like to communicate with, etc.?

Exercise "Self-examination"

Invite participants to tell you about yourself in the format of good news / bad news, what is going on and what does not happen in your life. Why still need to learn what knowledge and skills to get to be prepared to give attention and care to others?

\section{Lesson 4. Conscious Paternity}

A child needs a love and understanding for a complete and harmonious personality development. He should, whenever possible, grow up under the care and responsibility of her parents, and in any case - in an atmosphere of love, moral and material security. Declaration of the Rights of the Child, 1959.

Exercise "Child"

Give the definition of the word «child»: «The child is ...»

When discussing the emphasis is on positive definitions. 


\section{Exercise "My child".}

Parents should tell at their request:

- What are your children's names and why did you decide to choose them (names)?

- What kind of activity do you like to do with a child (what kind of toy to play, what book to read, etc.)?;

- What do you most like in your child?

Each of the parents must complete one of the following sentences:

"Two words that can describe my child are - ....";

"If my child was sound, then it would sound like ....»;

«My child makes me laugh when ...".

Exercise "Tree of Conscious Paternity"

Participants represent a conscious parenthood in the form of a tree:

The roots and basis of the tree are the definition of "conscious parenting";

The tree branches that form the crown are:

a) branch of knowledge - knowledge that will help parents in the development and upbringing of the child;

b) the branch of feelings - the feelings of parents in relation to their children;

c) a branch of abilities - skills that help parents to successfully perform the function of paternity and which should be owned by their parents;

d) a branch of qualities - features of character that should be inherent in conscious parents.

Exercise "The image of a happy child"

The leader offers using a sheet of watman, newspapers, magazines, threads, cloth, scissors, colored paper, glue, markers, create a collage: "The image of a happy child" and prepare a commentary on the result of the work for presentation. After group presentations, the psychologist draws attention to the fact that one of the components of the happiness of the child in the family is the presence of parents. He brings to mind that parents are happy when a happy child.

Exercise "Types of communication"

Parents are asked to compile a list of ways in which the child communicates with adults.

Answers are written on a sheet of notebook for the flipchart. They can be: crying (different kinds); movements; visual contact; eye tracking for 
objects, objects; smile; squeak; turning the head toward the mother (father); sucking (self-complacency); agoughing babble; conversation, etc.

It is important to pay attention to the importance of all ways of communication.

Exercise "Communication Style"

The participants are grouped into four groups, each group receives a card with a characteristic of one style of behavior.

Card 1. Authoritarian style of parenting behavior

Parents who are prone to authoritarian style:

- too hard;

- apply physical punishment;

- excessively control all child's actions;

- Demand from her constant obedience;

- Restrict the right to choose a child;

- do not want to compromise with the child;

- intolerant of childhood disadvantages and manifestations of «childhood».

Card 2. Liberal style of parenting behavior

Parents who are inclined to liberal style:

- exercise little control over the behavior of the child or control at all absent as a result of indifferent attitude towards the performance of parental responsibilities;

- practicing permissiveness;

- fulfill all the wishes of the child;

- unjustifiably idealize their child.

- How does a child feel to his parents in this way?

- How can parents' attitude to the child affect their personal development?

At the end, each group reads a behavior style card and offers a general review of the results of its considerations. After this, the leader gives parents the task of determining which parenting behavior is most conducive to the child's personality.

Exercise "Settings"

Parents analyze how often do they speak to children?

- Everything will happen to you!

- You are strong, do not give up!

- Thank you for helping!

- I'm on your side! 
- I'm proud of you!

- I love you!

- I am glad for your success!

- Everyone may be wrong, try again!

- Everything in life depends on you!

- I'm glad to see you!

«It's good for me when we're together ...!

- I like how you ...

"Come on, let's do it ..." together.

-You're so good!

It is discussed that most of the settings that children receive from their parents, further determine their behavior, is a guide to their personal development.

Give your parents a few minutes to exchange their thoughts in pairs.

What experience do you need to pass on to your child so that your dreams come true? What will you start with?

\section{Homework}

1. Analyze how you manage to understand your child. To do this, during the day (or preferably 2-3 days) try to count how many times you turned to him with emotionally positive statements (joyful greetings, approval, support, praise), hugged themselves, listened carefully, put their hands on their shoulders, rejoiced with together she was given a feeling that she loved her; and how many times you were angry, forbidden, remarked, punished, threatened, criticized, treated reproach. Would you like to be in the place of your child?

If the number of negative hits is equal to or exceeds the number of positive ones, then you are not all happy with communication and you should think about why one should praise the child, which statements to avoid.

2. Follow the emotions of the child. Fix the reactions of sympathy and antipathy and analyze what causes them. This will develop the habit of being careful and notice changes in the behavior of the child.

3. Close your eyes for a moment and imagine that you meet your best friend (or girlfriend). How do you show that he is glad that he is dear and near to you? Now imagine that this is your own child: here he comes home from school and you show that you are glad to see him. Imagined It's now easier for you to do this in real life, without any other words and questions. 
4. Embrace your child at least four times a day (ordinary morning greetings and kisses at night are not counted).

5. When performing the two previous tasks, pay attention to the reactions of the child and their own feelings.

6. Make a list of all kinds of behavior - actions and words that you regularly broadcast to the world (many laugh, laugh, do exercises, emotionally unstable, sit on the Internet). Discuss them with your husband, wife. Are there a lot of things you can be proud of? Circumvent the behavior (actions) that you would like your children to copy from you. Practice it regularly. Gradually eliminate your unwanted behavior.

7. Write the letter to yourself.

\section{CONCLUSIONS}

Thus, the program provides the opportunity to obtain the necessary information about the peculiarities of the upbringing of the child, the existing problems in relations with the child, as well as obtain their own experience of their solution. The result of participation in the program should be the construction of their own parenting position, changing the attitude towards the child - from awareness of themselves and the child as a unified system, to recognition of the child as an individual, who has his own subjectivity, as well as the construction of a system of communication with her as an equal partner on a trust basis.

There is no doubt about the therapeutic value of the program, as participants get a new idea of themselves and their families, develop their parenting skills, which contributes to their personal growth. Because of this, the program helps not only the integration and strengthening of the adult self, the development of a sense of confidence in their own emotional and behavioral manifestations and the ability to manage them, but also the awareness of life scenarios and personal meanings and values, in particular, awareness of the importance of the family, family values, the new integral entity of personality - paternity.

\section{REFERENCES}

1. Ponomareva-Semenova R.A. Methodological aspect of developing a psychological model of an extraordinary personality // Current problems of psychology: Volume 6. Gifted personality: search, development, help. (collection of scientific works). / Under the editorship of S.D. Maximenko. - K. "BONA MENTE", 2002. - Vip. 3. (Part 1) - P. 226-236. 
2. Subbotsky Ye.V. The child opens the world: Kn. for the child's teacher. the garden / E.V. Subbotsky. - M .: Enlightenment. - $1991-207$ p.

3. Druzhynin V.N. Psychological abilities / V.N. Druzhynin.St. Petersburg: Publishing House "Peter", 2000.- 368 p. : (Series of "Masters of Psychology").

4. Medina John. Rules for the Development of the Child's Brain / John Medina. - K . : Our format. 2015.

5. Leshaft P.F. Family medicine peder / P.F. Leshaft. - Moscow: Pedagogics, $2014-224$ p.

6. Druzhynin V.N. Psychological studies / V. Druzhynin. - Moscow: "KSP", 1996, 160 p.

7. Lisina M.I. Problems of ontogenesis of communication / M.I. Lisin // Scientific research. Institute of General and Pedagogical Psychology Acad. ped Sciences of the USSR. - Moscow: Pedagogics, 1986. - 144 p.

8. Hippenreiter Y.B. Communicate with the child. How? / Y.B. Hippenreiter, - Moscow : CheRo, 2001. - 240 p. : il.

9. Bern E. Games in which people play // E. Bern - Exmo, 2003. $576 \mathrm{p}$.

10. Schneider L. B. Family: Looking Back / L. B. Schneider. - SPb. : Peter, 2013. - 368 pp .: Il. - (Series of "Masters of Psychology").

11. Hovorun T.V. Basic preconditions for the emergence and resocialization of children and young people at risk groups / T. V. Hovorun // ScienceRise. - 2015. - No. 8 (1). - P. 84-89. - Access mode: http://nbuv.gov.ua/UJRN/ texc_2015_8(1)15

12. Nepomnyaschaya N.I. Formation of the personality of the child 6-7 years / N.I. Nepomniachaya // Scientific research. Institute of General and Pedagogical Psychology Acad. ped Sciences of the USSR. - Moscow: Pedagogics, 1992. - $180 \mathrm{p}$.

13. Bila I.M. Model of development of abilities at the childhood stage / Actual problems of psychology: a collection of scientific works of the Institute of Psychology named after H.S. Kostiuk, 2017, Vol. VI, Psychology of Giftedness, Vip. 13, pp. 20-31.

14. Hroff S. Outside of the brain. Birth, death and trans-centency in psychotherapy / S. Hrof. - Moscow: AST, 2005. - 495 p.

15. Rubinstein S.L. Abilities // Psychology of Individual Differences / ed. Yu.B. Gippenreiter, V.Ya. Romanova. - 3rd ed., Pererab. and add Moscow: AST: Astrel, 2008. - P. 31-46. 
Information about the authors:

Bila I. N.

Candidate of Psychological Sciences, Associate Professor at the Department of Psychology and Pedagogy of the V. I. Vernadsky Taurida National University 33, Ivana Kydri str., Kyiv, 01042, Ukraine 


\section{SOCIO-PSYCHOLOGICAL ASPECTS OF DEVELOPMENT OF PERSONALITY DEMOCRACIES IN MODERN UKRAINE}

\section{Vynohradova V. Ye.}

\section{INTRODUCTION}

The modern life is characterized by a rapid rate of development. The progress of all areas of human activity depends on people who perceive the world creatively and can achieve high results in a sphere of action. The importance of the problem of the creative development of the personality of a young person is perceived to the extent it is innovative in all state documents about education, speeches of specialists who are responsible for the development of the education system.

This is due to according to analysts up to $50 \%$ of workplaces in classical areas will disappear in the nearest future. However, in creative industries workplaces will be created sufficiently rapid pate.

The creative economy influences the educational system, youth, investment climate and investment attractiveness of goods, regions, and a whole country. The main values are the staff, its creative capabilities, and the non-standard approach to the case at the stage of transition from a market economy to a creative one that is characterized by the rapid growth of technology.

Creative industries are a set of views, ideas, trends, and trends of modern economic development which are characterized by an organic combination and the use of knowledge, information, and creativity.

Consequently, it is necessary in the modern world to develop not only creativity as a quality of an individual but also creative industry in general. That is, nowadays creativity has become a key vector for a society based on knowledge and economy. It contributes to all areas of public life such as politics, business, culture, art, and also is an instrument in the stable development of a country. So, the development of creative industries is extremely important.

It should be noted that studying the development of creative abilities has a long term way. Ukrainian and foreign scientists facilitate new development in studying this problem in the 21 st century. The process of 
formation of creative abilities worries scientists of all time and continents. Nowadays, scientists study not only the development of general and special abilities but also trying to identify the main approaches for developing creative thinking in children and adults. They study the creation of a model that can develop creativity clearly and step by step. The importance of the study is the necessity of theoretical synthesis and specification of the methodological foundations of the problem of the development of creative abilities (general psychology). The implementation of historical and psychological analysis of its scientific and conceptual, socio-value and personal factors (history of psychology), and building of an optimal educational and pedagogic environment in which there is an effective development of abilities and giftedness (age and pedagogical psychology) are the importance of the study as well. Creating conditions for early detection and development of creative abilities is one of the priorities of the modernization of national education which often remains focused on the so-called average student practically.

Consequently, the developed theories and concepts of the development of creative abilities in Ukrainian and foreign psychological science need to systematize the factors of its development and the establishment of such uniqueness which will provide a holistic understanding of the problem. This involves studying the main points of the way of life and the main factors that influence the development of the creative abilities of the individual. Scientists V.G. Panok and G.V. Rud have determined that the set of social, biological, and environmental factors that influence the person throughout his life are attributed to the life circumstances. An individually unique "personal history" and the individuality of each person should be determined ${ }^{1}$.

The scientists grounded the necessity to direct the attention of educational institutions to the formation of creative abilities during the educational process. However, if the factors of personality are taken into account, then this process is more effective in the significant opportunities of the socio-cultural environment. However, there are many difficulties in solving this problem.

Accordingly, we consider the problems of the development of the creative abilities of the individual which are connected with the sociopsychological factors that influence the development of the individual. In

\footnotetext{
${ }^{1}$ Панок В.Г., Рудь Г.В. Психологія життєвого шляху особистості: Монографія. - К.: Ніка-Центр, 2006. $-280 \mathrm{c}$.
} 
our opinion, the problems of personality formation under the influence of such systems as family, developmental space, and educational institutions should be considered.

\section{The influence of socio-cultural conditions for personality change development}

It is well known that one of the most important factors influence the development of the individual is the environment to the extent it is developing or vice versa. Nowadays, the issue of the development of creative abilities and talents tend not only corporations but the state and even the world. For instance, the Martin Prosperity Institute (the University of Toronto) provides data annually on the creativity and creative nature of 139 countries in the world. According to the index of creativity, countries are estimated by three indicators of economic development - technology, talent, and tolerance. It should be noted that the rating is influenced by the share of investments in research, the number of researchers and patents per head, the quality of education, and others.

According to the ratings of recent years, Australia has been recognized as the most creative country, in the second place - the USA, in the third - New Zealand. The top ten countries are Canada, Denmark, Finland, Sweden, Iceland, Singapore, and the Netherlands. These countries are considered to be very successful today. Ukraine was ranked 45th out of 139 in this ranking which is a rather high indicator. At the same time, Ukraine has quite good positions compared to many other countries by the level of talents that could contribute to the higher positions of Ukraine in this ranking. However, our country is still significantly losing positions in terms of tolerance of society. It should be noted that Britain introduced the creativity of employees into the factor of GDP formation in the country.

Professor John Howkins of Economics proposes to consider creativity as the main general capital. He identified three principles for the formation of a creative environment ${ }^{2}$.

1. This versatility of creativity (all people have creative abilities; they are given to each child).

2. Freedom (the actual attitude to any idea - to accept or reject).

3. Formation of markets and connections for the successful implementation of ideas.

\footnotetext{
${ }^{2}$ Хокинс Д. Креативная экономика. Как превратить идеи в деньги. - М.: Классика - XXI, 2011. - 172 с.
} 
At the same time, the main task is to transform freedom into effective economic activity.

The Analytical Center CEDOS has developed an index of the cultural and creative potential of cities. More than one hundred indicators were collected for the largest cities of Ukraine such as Dnipro, Kyiv, Lviv, Odesa, and Kharkiv. The research has determined the creative potential of the city, that is, how much the city environment can affect the development of personality creativity. The components of the city environment included the number of libraries, museums, theaters, cinemas, etc. Indicators showed how the significant opportunities of the city for the development of talent were. However, there are no such studies in all cities of Ukraine today. If we take these indicators, the environment contributes to the development of the creativity of the individual to a certain extent in large cities, taking into account the available opportunities. However, the environment is not adapted to develop the creativity of the younger generation in small towns and rural areas.

Professor Michael How of the University of Exeter believes that creative achievements are dependent heavily on general behavioral factors and environmental characteristics. He agrees that everyone is endowed with a gift of creativity but only a few people have the necessary qualities to develop it to the full. It is needed a long mood, an exact sense of purpose, a strong motivation for success, the ability to focus on specific tasks, and often understanding and support for homework.

Creative Director of Endemol Entertainment UK, one of the major European television program groups Peter Bazalgette calls six characteristics of creative people. The first characteristic is openness: "This means that you allow your consciousness to wander almost like a dream." The second quality is the independence of consciousness: "Creative people violate the rules but not establish them." The third characteristic - they are not afraid of changes. The fourth characteristic is "a test of a clean sheet ... creative people feel the challenge of space and try to put something on it." The fifth characteristic is a well-developed sense of humor. Then lastly, he states that creative people are ambitious and ready to compete ${ }^{3}$.

It should be noted that gifted people deviate from the norm not because they have some sort of rare abilities but they do not have a block or a filter that is applied on the talent that inherent with all. Researchers

\footnotetext{
${ }^{3}$ Хокинс Д. Креативная экономика. Как превратить идеи в деньги. - М.: Классика - XXI, 2011. - 172 с.
} 
concluded that the psychological nature of creativity is general to all. The rareness is our ability or a natural psychological opportunity to use it. There is the general innate ability to engage in creativity but not to the production of creative products. Anyone can dream and have an idea. Far fewer people can create a creative product. It depends on the technical skills, physical resources, and possibly environmental factors.

However, those children who find themselves in unfavorable conditions of the development, unfortunately, have rather insignificant opportunities for the realization of their potential. This is confirmed by numerous scientific studies of the influence of the environment on the development of creative abilities. For instance, according to the results of cross-cultural research of $\mathrm{P}$. Torrance, the following provisions are defined:

- Peculiarities of the environment affect the type of creativity and the process of its formation;

- The development of creativity is not genetically determined but depends on the culture in which the child develops;

- The development of creative abilities does not involve pausing in its process;

- Reducing the level of creativity can be explained by the extent to which new demands and stressful situations are encountered by the child;

- Creativity can be developed at any age through special education ${ }^{4}$.

Gippenreiter Y. having analyzed the conditions of education and heredity concluded that the factors of the medium are quite significant in comparison with the factor of heredity. They can compensate sometimes completely or conversely, neutralize the actions of the latter ${ }^{5}$ V. Druzhinin's confirms the previous statement. He believes that creativity is actualized only under significant opportunities for environmental. It is necessary to create the following conditions for the formation of creativity. Firstly, this is the presence of a positive sample of creative behavior. Secondly, this is the absence of a sample of regulated behavior. Third, this is the creation of conditions for the pursuit of creative behavior. Finally, this is a social reinforcement of creative behavior ${ }^{6}$. Salvador Dali advised:

\footnotetext{
${ }^{4}$ Torrance E.P. Rewarding Creative Behaviour. Experiments in classroom creativity / E.P. Torrance. Prentice Hall, 1965. - P. 353.

5 Гиппенрейтер Ю.Б. Общаться с ребенком. Как? / Ю.Б. Гиппенрейтер. - М. : ЧеРо, Сфера, 2003. $118 \mathrm{c}$.

6 Дружинин В.Н. Психология : учебник для гуманитарных вузов / В. Н. Дружинин. - [2-е изд.].СПб. : Изд. дом ПИТЕР, 2007. - 656 с.
} 
"It is necessary to create confusion systematically, it frees creativity." Creativity is complexity.

The conditions that are necessary for the demonstration of creativity are listed in a provision developed in the concept of humanistic psychology. It states that it is necessary to create conditions for identifying the child's internal capabilities. However, it is not necessary to speed up the creative development of a child. P. Torrance has identified the following conditions that can contribute to the formation and development of children's creativity. These are the orientation of a child to creative decisions; removing obstacles to the child's initiative; encouragement of creativity at home and in preschool; possibility to act with thoughts and objects; education of the child's knowledge of the value of the creative features of his/her personality; attention to all the properties of the environment. K. Rodgers distinguished internal and external conditions that contribute to the development of the creative potential of the individual. To the internal conditions he attributed the child's openness to experience; an internal evaluation of his/her creativity ("whether I am satisfied, but not satisfied with me"), and the ability to play with images and concepts. However, to obtain internal conditions, it is necessary to create external conditions. The external conditions include providing psychological safety (respect for a child as a person, the absence of external assessments), and psychological freedom (freedom in expressing their feelings and deeds).

Thus, the creation of an environment in which a child can be independent, exercise freedom of choice, respect for a child and the absence of excessive demandingness to him/her, and contributes to the formation of her creative abilities.

\section{Problems of development of personalities in the modern Ukrainian family}

A family serves as a model and an indicator of its problems in any period of development of society. The average family reflects the same economic, moral, spiritual, and value controversies that are currently present in the state. Therefore, the current socio-economic condition of the development of Ukrainian society highlights problems on the example of the life of most modern Ukrainian families. 
The great importance of the family in the upbringing of children is due to the peculiarities of its influence - continuity, consistency, and the fact that it educates not only through direct educational effects but also at the moral and sensory level which ensures high efficiency of the results and their long-term sustainability.

Tiutiunnyk V.I. notes that the need and ability to work in creative is formed for five years. In his opinion, the main factor contributing to the development of creative abilities is the impact of the relationship between the child and adults, and the attitude and position of adults towards a child.

It should be noted that there are the most advantageous, optimal terms in the development and development of individual abilities. There is an interesting observation of G. Lehmann Canadian scientist who has been working on this problem for about 20 years. In his opinion, the poets' age is determined between 26 and 30 years, doctors - 33-34, artists - 30-35, and writers $-40-44$ years $^{7}$. Giftedness can lead to the early development of abilities. Thus, the musical abilities of W.A. Mozart, J. Haydn, and M.A. Rimsky-Korsakov revealed in 4 years old; creative abilities of I.Y. Repin - at 4-5 years, and S. Raphael - at 8 years; A. Pushkin began to write the first verses in 9 years.

Some scholars identify the following factors that influence the formation and development of children's creative abilities:

- The harmony of relationships in a family between parents, between parents and children as well;

- Creativity as an indicator of personality as an example of imitation and the subject of identification;

- The commonality of intellectual interests of family members;

- Parents' expectations concerning the child: expectations of "achievements or independence" 8 .

However, there is an opposite position regarding the influence of harmonious relationships in a family on the development of creative abilities. These are a strict discipline, the same requirements for all children, and harmonious relationships between family members lead to the formation of certain social stereotypes and patterns of thinking making it impossible to develop children's creativity. The scientific research confirms the connection between non-harmonic emotional relationships in a family and the high creativity of children. Accordingly, it can be assumed

\footnotetext{
7 Леман К. Новий підліток до п’ятниці. / К. Леман. - [2-е вид.]. - К. : Брайт Букс , 2017. - 336 с., С. 49.

${ }^{8}$ Біла І.М. Психологія дитячої творчості. - К. : Фенікс, 2014. - 136 с., С. 61.
} 
that the most range of allowed behavioral (including emotional ones); less uniqueness of requirements and control contributes to the development of creativity. As a rule, a creative person is psychologically unstable and requires freedom. It is the requirement of parents of obedience that does not contribute to the development of independence and as a consequence, creativity.

If the parents pay attention to developing the abilities of a child and aim to develop his/her talent, this position is usually advantageous for the development of creativity. This process takes place under the influence of a favorable micro environment based on the general giftedness of a child, the formation of a system of motives, and personality traits. Thus, general giftedness is transformed into actual creativity (the synthesis of giftedness and a certain structure of personality). According to the researchers of creativity, the formation of these personality traits occurs in the period from three to five years.

According to D. Elkonin's research, children of preschool age develop approaches for the imitation of adult activities. Probably, during this period a child is as sensitive as possible to the development of creative abilities through imitation.

In the previous chapter, we have already highlighted the importance of a child's development environment. It is the family atmosphere that promotes the emergence of new thoughts and ideas, is the first necessary condition for the development of creative abilities.

In order to feel free in child's creative expressions, it requires the creation of an atmosphere in the first place, in which s/he will feel psychologically protected. The criticism of adults influences pretty negatively during this period. A friendly home atmosphere, permeated with spirituality, sympathy one-to-one family members, mutual understanding, a desire to be useful to their families, joint work, family holidays, folk customs, and rituals have an extremely profound influence on children and allow them to show their inclinations and develop creativity.

It should be noted that the formation of the individual requires longterm, systemic influence. Possibilities of the normal functioning of a family as a social institution are determined by its material security. The level of life and educational capacity of the family depends on the sociodemographic composition of the family such as the number of children, working and dependents, age of family members, their educational and 
professional level, etc. The most vulnerable are large families, single-parent families where one mother is raising children, and families with disabled children. Children in a family significantly reduce its financial capacity and average income per person. This level is 3 to 4 times lower in families with three or more children than in uniparous families which may be reflected in the conditions of the maintenance and upbringing of children.

The number of children in the parent's family affects the development of the creative abilities of each child. The interesting fact is that the greatest chances to show creativity, as a rule, have the eldest or the single son in a family. Fewer chances of showing creative abilities have children who identify themselves with their parents (a father).

In the information revolution, a large number of mothers and fathers are aware of the importance of the first years of child development. However, the information they receive is usually from the Internet and less often from books. This is not systematic, coherent, and purposeful for the development of the creative abilities of the individual. Hence, it should be noted that the main direction of society should be aimed at increasing the psychological and pedagogical literacy of the population.

Usually, a child comes to pre-school establishments in three years. Consider the realities of the present, a large number of children do not attend kindergarten because of the lack of places in kindergartens, their absence in many rural areas, and the family circumstances of parents. In most cases, children are deprived of a developing environment in which they can show their talents in a specific area. It should be noted that even if a child attends a pre-school, this does not guarantee him/her complete development. Consequently, an under three-years-old child and sometimes up to six grows and develops in a family circle. It is the parents who have to pay enough attention to personality development.

\section{Distinctions of the development of personal creative abilities in the educational system of Ukraine}

The impact of the educational system on personal formation and development is unquestionable. Today a great deal of attention is focused on the reform of secondary and higher education. The issue that comes on the foreground is not only gaining a certain amount of knowledge by children but the formation of an independent individual who is capable to use his/her creative potential. 
Creative abilities are considered as an integral property of personality and are defined as the high level of development of his/her abilities. An integral property of personality is studied in the context of the research on the development of skills and abilities, and individual traits of personality (N.S. Leites, K.K. Platonov, S.L. Rubinstein, B.M. Teplov), plus his/her stylistic aspects (O.V. Libin, V.S. Merlin), and the specific strategic activity (V.O. Molyako, T.M. Titarenko), including personality orientation (L.I. Bozhovich, A.M. Leontiev). The elaborated theories and concepts of the development of the creative abilities require the systematization of the factors of their maturity and equally the establishment of conceptual originality to provide a holistic understanding of the problem. It implies the study of historical links of conceptual tenets that presuppose further research perspectives.

In modern Ukraine, this issue is studied by such scholars as G.O. Ball, I.M. Bila, P.P. Gornostay, V.O. Molyako, O.L. Musika, L.P. Mishchykha, V.V. Rybalka, V.A. Romenets, S.O. Sysoev, etc. Among psychologists, however, there is a lack of consensus regarding the formation and development of creative abilities. A part of scholars hold that creative abilities and creativity are identical concepts that do not depend on the intelligence (J. Guilford, G. Gruber, Y.O. Ponomaryov, K. Tailor, P. Torrens); while others, on the contrary, find a correlation between a high level of intelligence and the creative abilities (G. Eysenck, D. Wexler, R. Sternberg). Also, some scientists argue that the motivations, individual psychological traits, emotional states along with other characteristics are the main factors for the disclosure of the creative abilities (D.B. Bogoyavlenskaya, A. Maslow, A. Olokh).

It is the well-known assumption that abilities are formed in the process of activities. Today the scholars in their researches, however, focus on the peculiarities of the psychological organization of the individual, namely, on the potential personal reserves because the creative attainment depends on them.

The analysis of the school system with general primary education demonstrates that it is mainly aimed at gaining the knowledge, skills, and abilities but not always accompanies by the development of the very creative abilities of the individual. It also should be noted that a child already starts schooling at age six or seven. And some sensational periods 
are passed over. As a result, the educational setting is no longer able to develop certain spheres of creative abilities.

Consider the impact of all parts of the learning environment on the development of personal creative abilities. In general, an important condition for organizing an inventive atmosphere is creating a sense of psychological security in children. It should be remembered that the critical remarks to the children and creating the feeling that their proposals are inappropriate lead to suppression of their creative abilities. In our opinion, it is important when the mentor treats the thoughts of the child without irony and with respect. Moreover, the educator should encourage the child to solve complex tasks to develop his/her motivation and persistence.

It is also necessary to note that the atmosphere and the physical setting exercise an important influence on the development of creative abilities. The children's room where preschool learning is performed should be designed following the chosen activities because the children must be able to move freely from one part of the room to the other without asking permission of a mentor. The group should be provided with various materials and equipment that are at the full disposal of the children. The mentor becomes the consultant and assistant to the children. While accomplishing the functions of general control over the activities in the group the tutor allows children to build the creative process by themselves. The well-known M. Montessori's system of the developmental environment is aimed at the comprehensive development of the child's personality and the formation of creative abilities. Unfortunately, it is poorly represented in Ukraine.

The next factor in the development of the child's creative potential, both in preschool and in school, is keeping the principles of personally oriented, developmental education, which directly ensue from the ideas of humanistic psychology (V.V. Davydov, L.B. Zankov, L.C. Vygotsky, D.B. Elkonin, I.S. Yakimanska, etc.). Developmental education is characterized by such an essential feature that creates a zone of immediate development. It also causes and facilitates or activates internal new psychic processes: the development of self-consciousness, feelings as a holistic process of personal development, because the values of life and moral norms only through feelings become personal values and norms of the developing individual, and are kept by him/her. It is also, suffices to say 
that the approach to the problem of developmental education is based on cultural-historical theory tenets of L.C. Vygotsky. The developmental education goal is apparent in the integrity and the utmost effectiveness of teaching, and the development of theoretical thinking (D.B. Elkonin, V.V. Davydov).

The goal includes such tasks as the formation of a learner, who is interested in self-transformation and capable of such changes, the comprehensive development, the development of cognitive needs, the formation of intellectually active personality, etc. In a person-oriented educational development, I.C. Yakimanskaya emphasizes the development of individual abilities of every child; maximum disclosing, initiation, usage, "culturing" of the individual (subjective) experience of the child; assisting the person rather in self-understanding, self-determination, and self-realization, than in the formation of predetermined characteristics ${ }^{9}$.

The person-oriented developmental education is characterized by the following presuppositions: the personality is manifested in an early childhood; from his/her birth a child is an entire human person, and he/she is a subject rather than an object in the pedagogical process; the personality is the goal of an educational system, but not a means for achieving other external goals.

A.M. Matyushkin sets forth the following principles of developmental education: problem, dialogue, and individualization. He considers that the conditions of the creative development are the problem-posing and dialogic, and individualized teaching. The disclosure of the creative potential involves activation and intensification of the developmental teaching of the children. It is rather important to teach how to think, and to find a solution to a problem than to give children ready-made answers. The problematic situation should be solved in a dialogue with the adult. The principle of individualization means that all kid's thoughts and statements, and all forms of their expression and demonstration are accepted ${ }^{10}$.

The development of personality following the principles of humanistic psychology is performed with the assistance of the following assumptions:

- To see in every child a unique person, to respect him/her, to understand, to accept, to believe in him/her ("All children are talented" this is the conviction of the teacher);

\footnotetext{
${ }^{9}$ Якиманська I. Особистісно орієнтована система навчання // Завуч. - 1999. - № 7. - С. 22.

${ }^{10}$ Матюшкин А.М. Проблемные ситуации в мышлении и обучении. - М., 1982.
} 
- To create the situation of success, overcoming, and achievement for the child;

- To rely on the positive traits of the personality;

- To exclude direct coercion, and also an emphasis on lagging and other disadvantages of the child;

- To understand the causes of child's ignorance and wrong behavior and correct them without degrading the dignity of the child's I-concept ("The child is good, but his/her deed is bad");

- To get excited by every child's idea, just as one can get excited by the baby's first steps:

a) To develop curiosity, the ability to raise questions,

b) To ensure independence in choosing and making decisions;

c) To comment positively all answers;

d) To use an error as an opportunity to look with new eyes at familiar things;

e) To be adapted maximally to all the statements and actions of children.

It should be noted that among the general pedagogical conditions of development of creative abilities of students in the process of learning the following are distinguished:

- Pedagogical stimulation of development of creative abilities based on the person-centered character of interaction between a teacher and pupils. The necessity to implement this condition is followed by modern social priorities. The person-centered interaction between the teacher and the student implies the choice of the characteristics of education and pedagogy as communication in which there are no sharp positions of the polarity of the student and the teacher. The process of education transforms into interaction. It contributes to the stimulation of activity, selfsufficiency, and the initiative of children; the combination of creative freedom and the direction of the students, emotionality, and expressiveness of communication with the expressions of respect and benevolence of participants in the pedagogical process.

- Application of psychological and pedagogical technologies that provide students with independent activity in the process of creative activity. The fulfillment of this condition must guarantee a positive motivation for the creative activity of junior pupils and provide an effective range of psychological and pedagogical incentives that will direct 
students' activity in the required direction. Such psychological and pedagogical technologies should take into account the peculiarities of pupils of different age groups, provide optimal conditions for students to express themselves, rely on material that is meaningful for students, involve their emotions in the process of creativity, encourage students in the process of creative activity to reflect their sensory experience in full, and provide the opportunity to create independently.

- System of educational work with pupils in the conditions of the creative and developing environment. In everyday life, knowledge is closely intertwined with each other, forming a unified system. Therefore, the student must see the object or phenomenon systemically in unity with the connections he enters. Maximum positive, favorable conditions for the development of children's creativity, including educational, for the upbringing of a creative person, creates a developing environment.

If study the development of the creative abilities of students, it should be noted that the demonstrations of creativity are quite controversial at this period. At this stage, the student solves mental tasks relatively easily, quickly, and efficiently. S/he can abstract freely from the concrete visual material and reasoning in a verbal way. Students are flexible, plasticity, ready for change and openness, and cooperation. The thinking of this age group is characterized by more flexible transitions in the interconnections of figurative, logical, and active components.

In parallel with the development of thinking, imagination and attention are developed. This is a positive factor in the manifestation of creativity $^{11}$. A student formulates a clearly expressed personal opinion and a self-chosen position. S/he has a huge creative potential that needs to be developed and which can not be given up. The activity of a person has a very significant significance for thinking as a higher mental process. Classroom activities are a prerequisite for developing students' skills and abilities to solve their problem tasks.

To formate creativity as a personal and not just behavioral, a specially organized environment is required. So-called "local" techniques for developing creativity (e.g. performing non-standard tasks) are useful. As a result of their use, students learn often only some new ways to perform a task and subsequently reproduce the assimilated actions (e.g. teams for participation in intellectual competitions are trained especially). In such

${ }^{11}$ Кривопишина О.А. Психологія творчості [Текст] / О.А. Кривопишина. - Суми: СумДУ, 2009. - 81 с. 
cases, creativity is showed in response to external actions in certain circumstances and not as a result of the personal needs of a subject. That is why a special environment is needed for the formation of creativity as a personal property that ensures a versatile systemic effect on the student.

Psychological and pedagogical conditions influencing the formation of the experience of creative thinking can be divided into objective (situational) and subjective (personal). Subjective conditions are persistent features of a person's character that can influence the conditions caused by a specific situation. Objective conditions include such an organization of educational process when the student's initiative is not suppressed, confidence in their forces and opportunities is formed, independence is stimulated, and an idea is developed. Subjective (personal) conditions are a set of person's characteristics influencing which (with the help of pedagogical approaches, methods, and means) the experience of creative thinking of future specialists is formed. Objective (situational) conditions provide an opportunity for purposeful pedagogical (formative) action, and also orientate it by the set of goals. This collection includes ${ }^{12}$ :

a) The person and behavior of the teacher. The teacher acts as the main actor in the technological process, organizes it, provides concrete practical interaction with students, integrates them into a common system of values, enhances motivational support of students, and activates their creative potential. The creative activity of the students increases when the teacher shows his creativity. The teacher has to create conditions and act in order to bring students the necessary, planned changes in consciousness, thinking, behavior, and relationships; his/her function is a real assessment of students' activity since it is the promotion and punishment that forms and establishes a habit; s/he should be a model and an example of a creative person who can and wish to orient students in their activities;

b) Material and technical base. Any professionally meaningful qualities, any skills, and abilities are based on knowledge. Acquiring the necessary knowledge by students is one of the most important tasks of the educational process. To acquire a sufficient amount of knowledge, students should not only have an interest in academic work and skills in independent teaching and research activities but also have the respective opportunities. These are a literary fund, computer support, the ability to use

\footnotetext{
${ }^{12}$ Иванова И.П. Развитие творческого мышления студентов в условиях проблемно деятельностного обучения / И.П. Иванова. - Ставрополь, 2002.
} 
the information databases of the Internet, and access to the cultural values of society;

c) Organization of the educational process. The organization of the educational process aimed at forming the experience of professional and creative thinking should be characterized by a problem. The necessity for additional information has created the necessity to resolve the contradiction between the existence of the problem and the impossibility of its solution under certain specific conditions. Therefore, this affects the student's motivational sphere-forming cognitive needs.

The process of forming students' creative thinking experience consists of purposeful interaction, co-creation of the teacher and the student in adequate specially organized conditions using the necessary mechanisms, forms, and methods of organizing classes.

\section{CONCLUSIONS}

Creativity is a universal talent common to humanity. Each person is somewhat creative. Consequently, the development of creative abilities can be carried out both at the personal level and the national level. Nowadays, a state program of the development of a creative environment should be formed. This would include all areas from the developing and the educational system including educational psychological and pedagogical activities with youth and families. Thus, the efforts of the state and the public should be aimed at the well-being and welfare of a family, creation of conditions for the development of the individual in society, in the education system, and the family. The family will be able to self-develop and its members can self-fulfill only in this case. All of this determines the necessity of the state family policy in Ukraine which is aimed at strengthening the social institution of the family. The direction of its implementation is social work with the family which takes into account its features as a social system, the primary collective, and a special small social group. Today, at the same time, there is an urgent necessity not only for social support for the family that has some problems in its life but also special work with difficult families which have more serious problems. There is not only a development environment for children in them but human rights violated systematically. Security agencies work traditionally with such families and human rights are protected by law but punishment is not the only way to work with such families. The main thing is to 
preserve the integrity of the family then there must be a long-term social work aimed at re-education of family members. The development state of the family in Ukraine requires a well-balanced state social policy that is aimed at supporting the family.

Consequently, the developed theories and concepts of the development of creative abilities in works of Ukrainian and foreign psychological science need to systematize the development of the factors.

\section{SUMMARY}

The article deals with the issues of development of the creative abilities of a child in modern Ukraine. The modern trends and directions of economic development characterized by natural combination and use of knowledge, information, and creativity are pointed out. The importance of developing creative industries in Ukraine is emphasized. Particular attention is paid to research on the development of creative abilities in educational and family environments. The most significant factors influencing the development of the creative abilities of the individual according to his/her age are analyzed. The basic factors of stimulation of the development of creative abilities based on person-centered character of interaction of the teacher with students, application of psychological and pedagogical technologies that provide the independent activity of students in the process of creative activity, and the systematic nature of educational work with students in conditions of creative and developing environment are determined. It is found that creativity is possible in any organization where innovations and inventions are possible. Creative abilities are developed in conditions that stimulate this process.

\section{REFERENCES}

1. Біла І.М. Психологія дитячої творчості. - К. : Фенікс, 2014. 136 c., C. 61.

2. Бурлачук Л.Ф., Морозов С.М. Словарь-справочник по психодиагностике. - СПб.: 1999. - 528 с.

3. Гиппенрейтер Ю.Б. Общаться с ребенком. Как? / Ю.Б. Гиппенрейтер. - М. : ЧеРо, Сфера, 2003. - 118 с.

4. Дружинин В.Н. Психология : учебник для гуманитарных вузов / В.Н. Дружинин. - [2-е изд.]. - СПб. : Изд. дом ПИТЕР, 2007. $656 \mathrm{c}$. 
5. Иванова И.П. Развитие творческого мышления студентов в условиях проблемнодеятельностного обучения / И.П. Иванова.Ставрополь, 2002.

6. Кривопишина О.А. Психологія творчості [Текст] / О.А. Кривопишина. - Суми: СумДУ, 2009. - 81 с.

7. Леман К. Новий підліток до п’ятниці. / К. Леман. - [2е вид.]. - К. : Брайт Букс , 2017. - 336 с., С. 49.

8. Лучшие психологические тесты для профотбора и профориентации. Описание и руководство к использованию / Отв. ред. А.Ф. Кудряшов. - Петрозаводск: Петроком, 1992. - 319 с.

9. Матюшкин А.М. Проблемные ситуации в мышлении и обучении. - М., 1982.

10. Методичне забезпечення діяльності психологічної служби. Інформаційно-методичний збірник / В.П. Мушинський, Н.В. Савєльєва, Л.О. Морозова. - Дніпропетровськ, 2006. - 44 с.

11. Моргун В.Ф., Тітов І.Г. Основи психологічної діагностики. Навчальний посібник для студентів вищих навчальних закладів. - К.: Видавничий Дім «Слово», 2009. - 464 с.

12. Панок В.Г., Рудь Г.В. Психологія життєвого шляху особистості: Монографія. - К.: Ніка-Центр, 2006. - 280 с.

13. Психологическая диагностика: Проблемы и исследования / Под ред. К.М. Гуревича. - М.: Педагогика, 1981. - 232 с.

14. Развитие и диагностика способностей / Отв. ред. В.Н. Дружинин, В.Д. Шадриков. - М.: Наука, 1991. - 181 с.

15. Хокинс Д. Креативная экономика. Как превратить идеи в деньги. - М.: Классика - XXI, 2011. - 172 с.

16. Якиманська I. Особистісно орієнтована система навчання// Завуч. - 1999. - № 7. - С. 22.

17. Torrance E. P. Rewarding Creative Behaviour. Experiments in classroom creativity / E. P. Torrance. - Prentice Hall, 1965. - P. 353.

\section{Information about the author: Vynohradova V. Ye.} Dr (PhD), Associate Professor, Head of the Psychology and Pedagogy Department of the V. I. Vernadsky Taurida National University 33, I. Kudry str., Kyiv, Ukraine 
DOI https://doi.org/10.36059/978-966-397-109-4/93-113

\section{GENDER DISCRIMINATION: VIEW OF STUDENT YOUTH}

\section{Kostina T. O.}

\section{INTRODUCTION}

Today, the issue of discrimination in general and its varieties is acute in Ukraine, which manifests itself in the form of gender-based discrimination. Despite the fact that attention to this issue is already at the state level, which is manifested in the adoption of relevant laws that should reduce the level of discrimination in Ukrainian society.

Adoption of the relevant legislative acts requires from Ukraine representatives of the European Union and other countries of a democratic society. It is clear that any actions, deeds or inactions of a person in a society should be regulated by the relevant legislation. The existence of such laws can appeal to the establishment and observance of certain rules of conduct that are not harmful to people and are consistent with the basic principles of democracy.

It should be noted that apart from a purely legal plane, any phenomenon also has a psychological component. The psychological plane contains certain "unwritten" rules, norms of behavior, which usually contain the context of ethics and morality. However, everyday life often encounters "rules" that in their essence contradict generally accepted human values and thus provide the basis for the deployment of various negative phenomena. One of these negative manifestations is discrimination, in particular, gender-based discrimination.

We emphasize that no norm that functions in one or another society can not go against the democratic values of freedom and equality. Is that really true? And can socio-psychological stereotypes really be overcome through legal action? In our opinion, only the legal plane is not enough. Particularly in the subject of discrimination, which "cling" to the deep levels of the human psyche. 
That is why it is important for us to investigate the psychological aspect of this phenomenon and, based on the findings, to create optimal conditions for the formation of gender equality in the territory of Ukrainian society.

The main purpose of this article is to determine the specificity of the attitude and level of awareness about gender inequality among the student youth. Our scientific research focused on the study of the views of young people (students) on this issue, because it is the young people who can become the driving force that will help to overcome inequalities in Ukraine. After all, they are the future of our country, and first and foremost depends on them, which way the Ukrainian state and society will go.

\section{Approaches to the definition of discrimination. Gender discrimination}

To understand the concept of gender discrimination, it is necessary to clarify the original components: the concept of "discrimination" and "gender".

The term "discrimination" comes from the Latin "discriminatio" and literally translates as "distinguish". According to S. Ozhegov's explanatory dictionary, discrimination is denoted as: "to restrict rights, to deprive equal rights" . Discrimination in the Ukrainian language dictionary is defined as: "restriction or deprivation of the rights of certain categories of citizens by race or nationality, political or religious beliefs" 2 .

The Cambridge Dictionary denotes discrimination as a practice of dealing with a person or group of people less equally than other people. Typically, the factors that lead to manifestations of discriminatory behavior are the color of the skin, gender, age, race $^{3}$.

The word "gender" was originally used in linguistics to refer to the notion of gender as a grammatical category. Later, the term was fixed in the socio-psychological plane.

The term delineates the concept of biological sex and social. Biological gender refers to the biological, anatomical and physiological differences between the organisms of women and men. It is these differences that ensure the reproduction of the body. For a deeper understanding of the concept of sex, we will analyze the concept proposed

\footnotetext{
${ }^{1}$ Ожегов С.И., Шведова Н.Ю. Толковый словарь русского языка (А-Д) Издательство “Азъ”,

2 Словник української мови : [в 11-ти т.] / [ред. кол.: І.К. Білодід (гол.) та ін.]. Київ: Наукова думка, 1970-1980. Т. 2: Г-Ж / ред. тому:П.П. Доценко, Л.А. Юрчук. 1971.550 с.

${ }^{3}$ Кембриджський словник. URL: https://dictionary.cambridge.org/
} 
by the American psychologist John Mani who identified eight stages of sexual differentiation:

1) chromosomal or genetic sex (genotype: $\mathrm{XX}$ or $\mathrm{XY}$ );

2) gonadal sex (ovaries / testicles);

3) gametta sex (sperm / egg);

4) hormonal sex (androgen and testosterone / estrogen and progesterone);

5) morphological (somatic) sex (penis / clitoris and vagina);

6) civic sex (phenotype: male / female);

7) sex, which arose as a result of education;

8) sexual identity ${ }^{4}$.

The first six stages of J. Mani are called biological, the last two psychological. The formation of a "psychological" gender is due to social roles that pass into the gender of the biological. Clarify the notion of a sexual role.

Sexual role is a system of norms and regulations concerning the behavior of men and women taken in a particular social environment. Behavior, which is consistent with the accepted distribution of sexual roles in a given society, is called sexually typed. These are the so-called "female" (mother, hostess) and "male" (defender, leader) roles that exist in the form of feminine and masculine rice respectively.

Here is a definition of the concept of "sexual identity".

Sexual identity is awareness of the individual as a representative of one sex or another. Domestic scholars on gender issue T. Govorun and O. Kikinezhdy offer the following definition: "Sexual identity is a subjective understanding, an experience of sexual role, a peculiar unity of sexual self-awareness and behavior" 6 .

Thus, we see that the formation of a "psychological sex" (according to J. Mani) can not take place without the influence of society. Since we are talking about the influence of society on the formation of a subjective experience of oneself belonging to a certain gender, our scientific search should go into the plane of coverage of the gender issue.

\footnotetext{
${ }^{4}$ Говорун Т.В., Кікінежді О.М. Стать та сексуальність: психологічний ракурс. Тернопіль: Навчальна книга - Богдан, 1999. $343 \mathrm{c}$.

${ }^{5}$ Шевченко 3.В. Словник гендерних термінів. Черкаси: видавець Чабаненко Ю., 2016. URL: http://a-z-gender.net/ua/\%D2\%91ender.html (дата звернення 03.05.2019).

${ }^{6}$ Говорун Т.В., Кікінежді О.М. Стать та сексуальність: психологічний ракурс. Тернопіль: Навчальна книга - Богдан, 1999. $343 \mathrm{c}$.
} 
The term "gender" denotes social expectations about the roles that representatives of one or another biological sex must follow. The idea of dividing the gender of a biological and social belongs to the anthropologist Margaret Mead, who voiced this in his work "Gender and Temperament in Three Primitive Societies"7.

During the study of primitive tribes living on the territory of New Guinea, M. Mead came to the conclusion that the independence of such characteristics as "masculinity" or "femininity" from the sex of a person.

The obtained results have allowed a new look at the influence of social and cultural expectations on the formation and consolidation of those or other behavioral patterns of a person.

It should be noted that the term "gender" became much wider after its distribution. In the 1970s, the 20th century, thanks to the works of American scholar Robert Stoller, who proposed the term "gender identity".

According to R. Stoller's views, the biological basis - sex - must be studied within the limits of biology and physiology. And gender, as a social phenomenon, according to $R$. Stoller, must be studied by psychologists and sociologists who study cultural and historical phenomena ${ }^{8}$.

Gender identity is "the experience of its own compliance with gender roles, that is, the set of social norms and stereotypes of behavior characteristic of the representatives of a certain sex"9. It is necessary to distinguish gender identity and gender. Yes, a person can have a clearly defined gender identity and have difficulty with gender: to experience a mismatch with the male and female ideals.

In the structure of gender identity, three components are distinguished:

- cognitive - awareness of belonging to a particular sex and a description of yourself based on the categories of masculinity-femininity. This is the self-concept of a man or a woman;

- assessment - involves the assessment of personality traits and features of role behavior by correlating them with reference models of masculinity-femininity;

\footnotetext{
7 Mead Margaret. Sex and Temperament in Three Primitive Societies (1st Perennial ed.). New York: Perennial an impr. of HarperCollins Publ., 2003. 352 p.

${ }^{8}$ Шевченко 3.В. Словник гендерних термінів. Черкаси: видавець Чабаненко Ю., 2016. URL: http://a-z-gender.net/ua/\%D2\%91ender.html (дата звернення 03.05.2019).

Шевченко 3.В. Словник гендерних термінів. Черкаси: видавець Чабаненко Ю., 2016. URL: http://a-z-gender.net/ua/\%D2\%91ender.html (дата звернення 03.05.2019).
} 
- behavioral - self-presentation of oneself as a representative of a gender group, as well as overcoming the identity crisis by choosing behavior in accordance with the personality of meaningful goals and values ${ }^{10}$.

It is clear that the outlined components of gender identity do not function in isolation but are interconnected. In addition, the defined structure allows for correction (if necessary) to stabilize the image of a person about himself and his social roles (including gender). Since the perception of the person of these components will allow her to understand more deeply about where exactly there is the greatest "strain" in her gender identity. And so she will be able to focus on this.

Gender discrimination is based on gender stereotypes that have emerged in society. Typically, according to these stereotypes, women and girls are considered less significant and have lower social status than boys and men $^{11}$.

However, men also suffer from discriminatory manifestations. They are subject to the "restrictive" stereotypes that encourage boys to be more "masculine", which in turn can increase the appearance of discrimination against women.

Restrictive thoughts about the qualities of the representatives of different sexes do not allow boys and girls to be free to choose their way of life. Because the environment imposes "prohibitions" on manifestations of one or another behavior in accordance with stereotypes "female", "male".

Gender discrimination manifests itself in the fact that the person is not based on his knowledge, skills and professional achievements, but only on the basis of belonging to a certain sex.

A person may encounter various types of discriminatory actions. These actions can take place at school, at work, in communicating with other people. Typically, discriminatory actions include:

- sexual harassment, catcalling on the street;

- gender stereotypes at school and at work;

- objectification (the physical attractiveness is brought to the fore and the person is actually dejected);

- $\quad$ poor representation of women / men in certain activities ${ }^{12}$.

\footnotetext{
${ }_{10}^{10}$ Малкина-Пых И.Г. Справочник практического психолога. М.: Изд-во Эксмо, 2007. 784 с.

11 Challenging gender discrimination: a how-to guide. URL: https://plan-international.org/girlsget-equal/calling-out-discrimination

Challenging gender discrimination: a how-to guide. URL: https://plan-international.org/girlsget-equal/calling-out-discrimination
} 
It should be noted that gender discrimination has deep roots, which is fueled by culture, traditions, religion, etc. That is why it is very difficult to change the gender stereotypes as they are related to the deep layers of the human psyche.

These layers are usually not understood by a person and are absorbed by it from the surrounding environment as a certain "reality" that exists and which does not need to be rethought.

Person simply "swallows up" certain ideas. And these perceptions people perceive as their own beliefs. And therefore he/she is actively trying to defend them and not refuse them.

Such representations, beliefs, settings, etc., which were "borrowed" by a person from the environment, were called "introject". The formation of introject is provided by a process called "introjection".

Introection (from lat intro - inside and lat. jacio - throw, lay) - this is an unconscious psychological process, which belongs to the mechanisms of psychological protection of the psyche. It manifests itself in the "appropriation" of a person's views, thoughts, beliefs of the people around person, which did not belong to himlher before meeting them.

However, as a result of introjection, these thoughts, beliefs, settings, etc., are perceived by the person as their own and transmitted to her inner world. It should be noted that this process of "appropriation" of other people's thoughts takes place at an unconscious level and does not fall under a critical rethink. This term was proposed by Hungarian psychoanalyst Ferenczi Sándor in 1909. Introection is a primitive form of identification, but unlike the identification, introjection is not realized ${ }^{13}$.

The concept of introjection further develops in gestalt therapy, the founder of which was F. Perls. In the Gestalt approach, the appearance of introject is also due to the transition of external rules to internal rules. They explained this process based on the analogy with the process of absorption of food, when a person "swallows" everything that the surrounding world gives her/him without a critical reflection of what person "consumes",

The presence of introjects in the human psyche is a factor that ensures the formation of a huge number of attitudes and sets, which begin with the words "I must".

\footnotetext{
${ }^{13}$ Мак-Вильямс Н. Психоаналитическая диагностика: Понимание структуры личности в клиническом процессе. М.: Класс, 1998. 480 с.

${ }^{14}$ Перлз Ф. Практика гештальттерапии. М.: Институт Общегуманитарных Исследований, 2005. 480 с.
} 
There are no exceptions to the introjects that regulate the functioning of the person at the level of gender roles. That is why, on our way of life, we can meet a large number of adults who operate categories that are introjects in nature. For example, "a man must be strong", "a woman must be weak", and so on.

Sandra Bem made a significant contribution to understanding the concept of gender and stereotypes related to this concept. In her work "Gender Lens: The Transformation of Views on the Problem of Sexual Inequality" (1993), the researcher proposes a model for gender stereotypes and develops the theory of gender schemes ${ }^{15}$. According to this theory, sexual typing occurs on the basis of gender schematization, which manifests itself in the ability of children to codify and organize information, including self / self, in accordance with the cultural definitions of male and female. Thus, this theory emphasizes that sexual typing occurs on the basis of cognitive processes that are present in the child.

However, in the theory of gender schemes it is emphasized that sexual typing is not only the cognitive activity of the child himself/herself. But this is also the process of social learning, in which the child is faced with the fact that her/his certain behavioral manifestations are supported by adults, while others are not. Thus, there is a process of learning that incorporates socially established stereotypes about "female" and "male" roles.

Gender research sooner or later brings researchers to the issue of gender discrimination. Particularly relevant is the question: how to counter gender-based discrimination. And what is the role of youth in supporting or opposing discriminatory processes in society. That is why our empirical study aimed to identify the peculiarities of gender-based discrimination on the part of young people.

As we see, the issue of gender discrimination has deep roots and needs to be studied not only at the social level, but also at the deep-personal. Our study concerned only the social level and determined the "actual" limits of social existence of this phenomenon. However, we understand that the prospect of research on the gender issue is the study of the underlying processes that unfold during the formation of the individual and which, in turn, will influence the further deployment of her/his life path.

\footnotetext{
${ }^{15}$ Бем С. Линзы гендера: Трансформация взглядов на проблему неравенства полов / [пер. с англ.]. М.: «Российская политическая энциклопедия» (РОССПЭН), 2004. 336 с.
} 
The formation of a life path under the influence of unconscious decisions taken in childhood brings us to the concept of a life-script that was developed within the theory of transactional analysis. Researchers of the theory of transactional analysis studied the formation of "female" and "male" life-scripts under the influence of unconscious decisions of the individual ${ }^{16}$. This problem has a significant scientific potential and needs more detailed study in our further research. In this paper, we are doing a brief overview on of how young people (students) see gender discrimination.

\section{Gender discrimination: student's view of this phenomenon}

Our research was conducted at the V.I. Vernadskyy Taurian National University (Kyiv). Participants in the survey: permanent residents studying in the fields of psychology, social work, history and archeology and secondary education. Total number of respondents: 51 students (14 boys and 37 girls). The average age of the subjects 19 years. It should be noted that all participants in the survey did not receive training, lectures or special courses on issues of discrimination, including gender-based discrimination. The survey was conducted in the form of a written questionnaire and took place in April 2019.

Procedure of the study: respondents were given questionnaires with a list of questions they were supposed to give a written answer. If a student has some difficulties, he/she raised his hand and the experimenter gave him/her some help: answered the clarifying questions. Students did not have time limits for completing the questionnaire. The average time for filling in the questionnaire was 20 minutes.

Also, after completing the questionnaire with students, a mini-lecture was held with a follow-up discussion on what gender-based discrimination it is. Such discussion allowed to determine the features of understanding the phenomenon of discrimination by student youth. Also, this form of polling organization has made it possible to compare their representations (written answers) with what is described as gender discrimination in accordance with international and national documents.

\footnotetext{
${ }^{16}$ Steiner C. Scripts People Live: Transactional Analysis of Life Scripts. Grow Press: New York, 1990. 332 p.
} 
The obtained data was entered into the SPSS program, which provided quantitative data analysis. However, for a deep understanding of how the concept of "gender discrimination" is interpreted by young people, we carried out a qualitative analysis of the data.

The questionnaire contained open questions that required an expanded answer from the students' side. In particular, young people were asked to define what "gender discrimination" means; Determine whether discrimination is a biological or social basis. Describe the cases when they encountered gender discrimination in their own lives. There was also a question as to whether they displayed gender-based discrimination in relation to others.

This list of questions allowed to determine the number of discriminatory cases that occurred in the life of a young person. The open form of the question allowed to determine the specificity of this discrimination. The final question was whether students want more information on gender discrimination and in what form (lectures, trainings, discussions, etc.).

It is clear that such a number of subjects does not allow us to extrapolate the results obtained to all student youth of Ukraine. However, the purpose of this survey was to determine if there is a general demand from young people for a "meeting" with such a topic, and their desire to receive additional knowledge on inequities.

The question about the grounds on which gender discrimination is based (biological or social), the majority of respondents (41 students, $80 \%$ ), attributed to a socially determined phenomenon. The biological basis was determined by 4 respondents $(8 \%)$, a combination of biological and social 6 subjects (12\%). The illustrated results are presented in Fig. 1.

As we see, the vast majority of students regard gender discrimination as having a social basis. Thus, for most young people, discriminatory manifestations do not find their explanation in the area of biological differences between women and men.

Answers to the question "Have you encountered in your life with gender discrimination?" Answered the young people in the following way: 28 respondents answered positively (55\%), negatively 23 students (45\%). The distribution is presented in Fig. 2. 


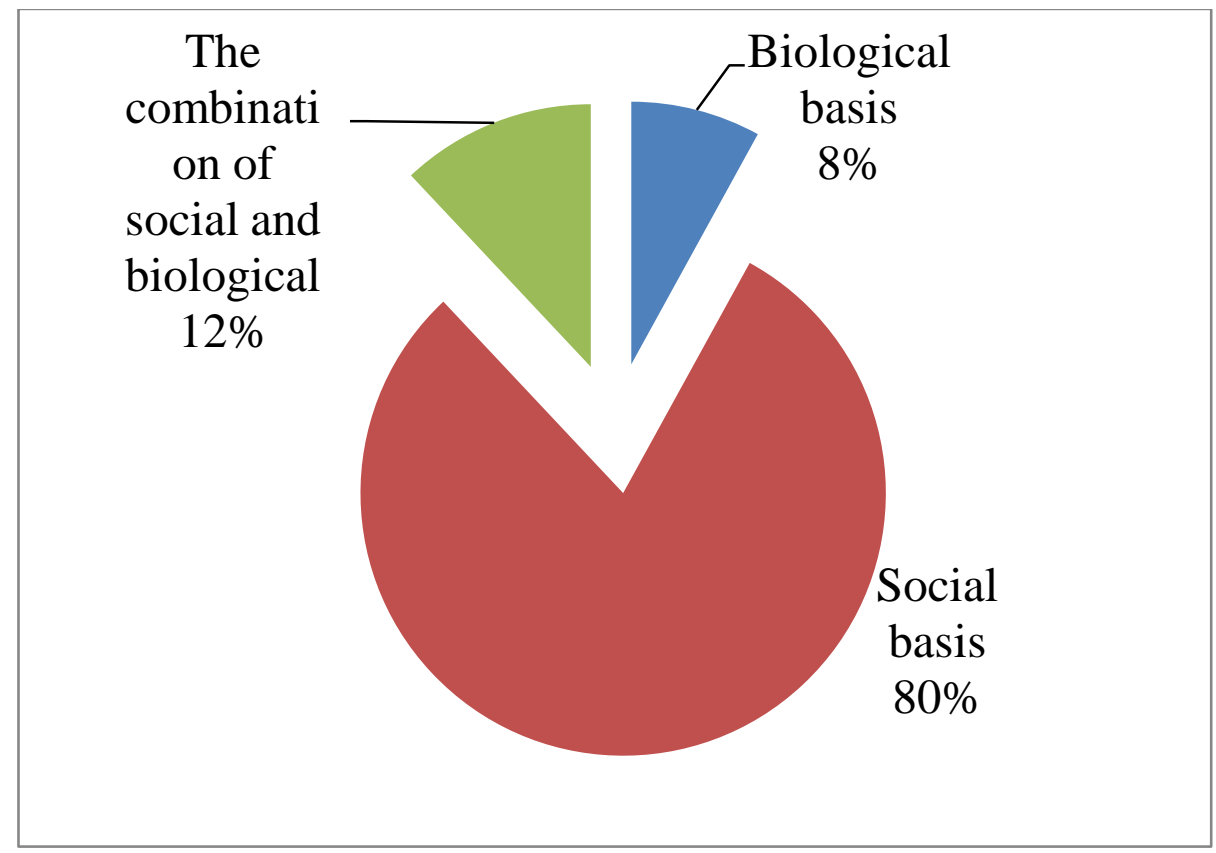

Fig. 1. Distribution of respondents on the question of the basis of gender discrimination

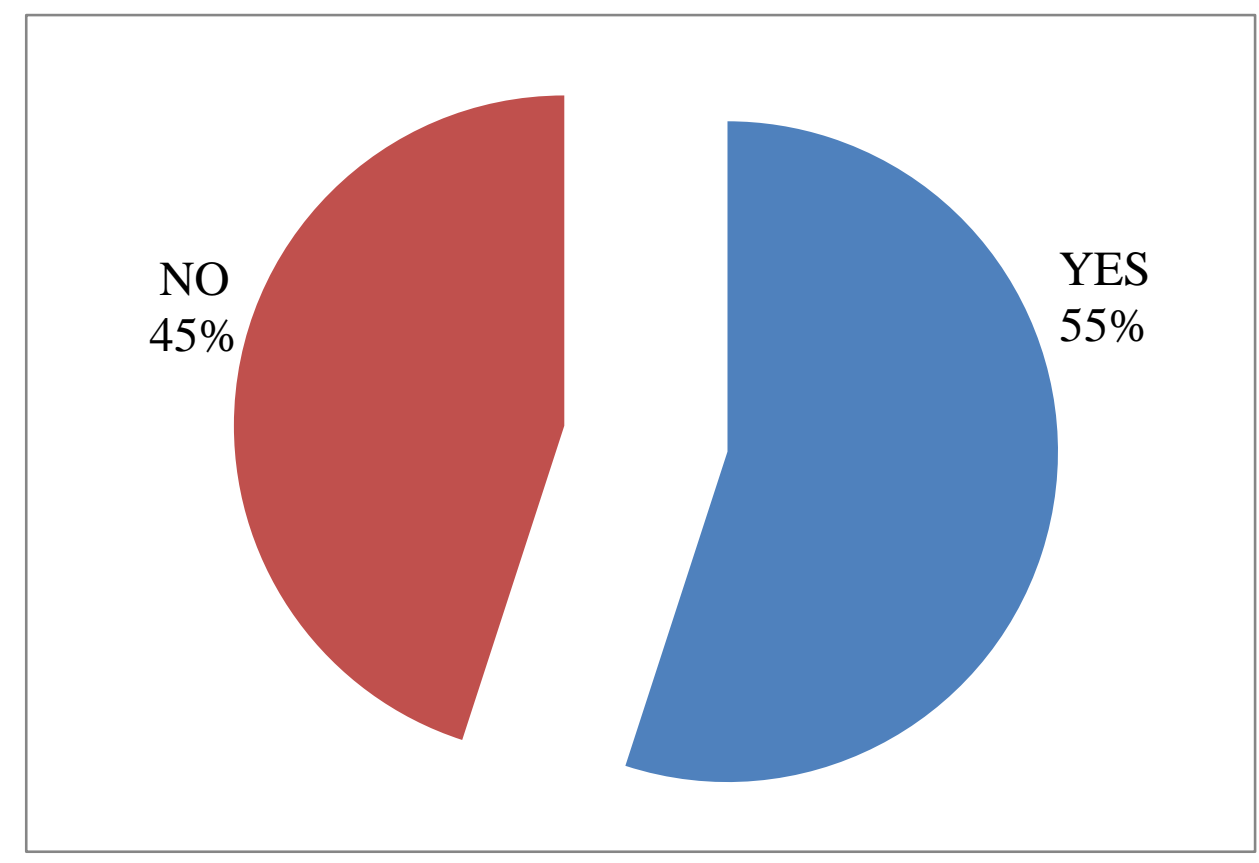

Fig. 2. Distribution of respondents to the question "Have you encountered gender-based discrimination in your life?"

The results suggest that young people meet in their lives with gender discrimination. However, we also see that $45 \%$ of respondents indicated that 
they did not face discrimination. It should be noted that after the questionnaire we also had a mini-lecture with a further discussion on what gender-based discrimination is.

Thus, among respondents who gave a negative answer to the question "Have you encountered gender discrimination in your life?". Some of them did not have sufficient level of awareness on this issue and did not include stereotyped statements, anecdotes, etc. to gender discrimination. In particular, the statement that "a woman, above all, mother, and then everything else" does not regard them as a manifestation of discrimination. In relation to a man, the stamp "men - do not cry" indicated that all respondents $(100 \%)$ heard, but did not attribute it to a discriminatory component. In this way, we see that in Ukrainian youth there is a certain "resistance" to such kind of stable discriminatory statements. The results suggest that the issue of educating young people on gender issues is of great importance for modern Ukrainian society.

It should be emphasized that for our study, a qualitative analysis of the data was important. The quantitative indicator was important in the context of whether a person was exposed to discrimination in his/her life. Because the number of respondents for us was an indicator of whether this issue is relevant to Ukrainian society as a whole, and for student youth in particular.

However, the purpose of this survey was to determine the specificity of understanding and attitude of students towards the manifestations of gender discrimination. That is why, in most cases, the qualitative indicators of the conducted research (examples of answers) are given, rather than quantitative ones. It should be noted that some definitions were duplicated by some students, but they still had their own specifics, which distinguished this answer from the responses of other participants in the study.

One of the questions that contained the questionnaire was the definition of gender discrimination and its understanding by young people. A large number of respondents attribute gender-based discrimination to violation of rights, especially women, when they can not fully realize themselves in society, in particular, under the pressure of the "male world".

Here are some of the definitions of gender discrimination that students have given: "This is the benefits of men (in most), oppression of women's rights"; "When someone is humiliated in rights"; "It impedes the rights of people of a certain sex, for example, it is believed that women are a weak sex"; "The oppression of one sex or another in all spheres of life"; 
"...."female" and "male" roles that do not take into account the person's predisposition and limit their rights and freedom"; "When women and men are not equal in their rights", "When a man humiliates his wife and does not allow her to be realized in the profession, because work is "for intelligent and strong men".

Students also associate this term with the process of humiliation: "Gender discrimination is the humiliation of someone on a gender basis"; "Humiliation by sex, gender"; "Gender discrimination is a situation where women and men are not equal in rights and abilities and beliefs about them"; "When women and men are not equal", "Humiliation on the basis of sexual identity".

Gender discrimination was also linked to the existence of certain privileges, advantages on the one hand (and their absence from the other): "the existence of certain privileges for one sex (women, men)"; "... preference is given to a person of one sex in different spheres of life: during employment, remuneration of labor, manifestation of sexual harassment, domestic violence".

Students also linked discrimination with the ability to choose a professional path by the personality and the presence of an established division of responsibilities in society: "This impediment of the right to choose a profession and professional implementation", "This is a clear division of responsibilities".

Some students did not differentiate between sex and gender, defining gender discrimination as "Judging a person based on her/his sex". It should be noted that such an interpretation does not go beyond the generally accepted definition. Since the general definition of gender discrimination is presented as "sex-based discrimination"17. Thus, the lack of definition of the word "gender" does not go beyond what has been accepted.

It should be noted that in most cases, we have seen definitions that were intended to emphasize the impact of the actual non-biological sex, and the social expectations and stereotypes associated with the sex. That is, this led to the concept of gender as a social category.

Here are some examples of student definitions that include a social component in the context of gender discrimination: "Discrimination based on sex associated with stereotypes of society."

\footnotetext{
${ }^{17}$ Виртосу I. Гендерна дискримінація: Як не наступити на граблі старими мозолями? URL: https://humanrights.org.ua/material/gendernajia_diskriminacijia_kak_ne_nastupit_na_grabli_starymi_mozoljiam і (дата звернення 04.05.2019).
} 
As we see, in most cases, students associated discrimination with the phenomenon of inequality, oppression of rights and the pressure of certain stereotypes that prevent a person from fully revealing his/her potential and choose the life path that he/she likes.

Interpreting the results of the number of students who encountered gender discrimination would not be complete without a qualitative analysis of the responses of young people. The qualitative component was obtained through the question "Give an example when and how you encountered gender discrimination".

A significant number of respondents indicated that they were faced with discrimination on the basis of sex in the labor market (in the process of employment). Thus, a vivid manifestation of gender discrimination was an example when a student described that she was not working with an employer who was "male". The student noted that the work was to compile tables for the company. Thus, we see discrimination at the level of mental impairment due to being a female. In addition, a significant number of respondents indicated that they encountered such restrictive phrases as "This is not a women's affair".

An interesting example was the response that demonstrated the presence in Ukraine of so-called reverse discrimination, which manifests itself in discriminating against the majority (representatives of the dominant group) by members of the minority group. For example, a man may be denied a job because of the fear of accusations of sexism if a woman is a competitor to this position" ${ }^{18}$ "I met the fact that in some companies the advantage is on the contrary given to women, especially if they are representatives of the LGBT community", said one of the students in the poll.

Examples of discriminatory experiences were as follows: "I often hear from others: "What do you want from her, she's the girl" or "You still do not understand me, you're the girl". In these examples, we see a biased attitude towards another gender based on prevailing social stereotypes.

Students who demonstrated their desire to identify their personality beyond the established stereotypes (in particular, on the level of image) demonstrated their particular pressure. Such students encountered resistance and received phrases such as "You are a girl, you have to wear a dress!”.

18 Шевченко 3. В. Словник гендерних термінів. Черкаси: видавець Чабаненко Ю., 2016. URL: http://a-z-gender.net/ua/\%D2\%91ender.html (дата звернення 03.05.2019). 
If we talk about stereotypes (and they are themselves related to gender discrimination), then it should be noted that they have many imperatives, that is, a high level of compulsory nature. This obligation is manifested in phrases such as "you must" with further condemnation from the environment if a person shows intention not to go through the established "duty" and defines for himself/herself other priorities.

Today, the term "stereotype refers to the established pattern of thinking, prejudice, which, as a rule, has no direct relation to reality. The term was proposed by U. Lippmann (1922), which became part of the socio-political discourse of Western European countries, and then spread to other countries. Today, the study of stereotypes is carried out within the limits of psychology, social psychology, especially in the context of the problems of discrimination.

The main question is: "Why do people use stereotypes?". The answer is simple. With the help of stereotypes, a person saves the resources of his psyche, because the presence of stereotypes simplifies the vision of the surrounding reality. For example, stereotypes about men and women can allow a person to make certain "conclusions" about the person with whom he/she communicates. Thus, a person has a certain intention to react to an interlocutor before he or she answers. And what can be expected from the person with whom you enter into interaction (the "prognostic" function of stereotypes).

The stereotype is not reality, it's a strategy for simplifying reality. Since, having certain stereotypes, people are more likely to process incoming information and give an answer. It is clear that such a response is very simplistic and incapable of taking into account the individuality of the subject with which this person communicates.

In the context of gender stereotypes, we have such patterns as "women - emotional beings", "men - rational beings". Therefore, often we question the woman's ability to make rational, weighed decisions. And we see men as being deprived of emotion. It is clear that such stereotypes do not correspond to reality.

However, during the historical formation of mankind, they deeply entered the society. And since stereotypes are formed rather early (in childhood), it is difficult to rethink them in adult life. However, due to special education and psychological training, significant changes can be made in the context of changing stereotyped attitudes, in particular gender issues and gender discrimination. 
Respondents also noted that in relation to them were put forward requirements for the implementation of her future reproductive function: "Do not raise the hard, you have children to give birth". In this example, we see the stereotypical representation of society, which often places the mother in the forefront of women. Other roles (business lady, traveler, etc.) are considered as minor, or in general, as non-eligible. We remember a wellknown saying about what should go to a circle of women's interests: children, cuisine, church. It is clear that such stereotypes restrict the woman in her quest for the realization of her potential as a person.

Also, the respondents cited examples of discriminatory jokes that are often heard in the direction of a woman: "Your place in the kitchen", "Silence, woman, your day is the eighth of March". Examples of women's ability to drive a car (negative assessment): "All problems on the roads, through female drivers".

In addition, men were discriminated against in their ability to raise children (devaluing their abilities in comparison with women). They gave examples of communication with older generations when they believe that "a man to go to maternity leave is ashamed".

Students also said that they faced discrimination when women were told that they had to "cook, clean the house", that is, to fulfill "female" duties.

Young people often encounter life situations (on an example of a parent's family or friends and relatives' families) when a man drops all his domestic work to a woman by motivating it, "You are a woman, you have to lead a housekeeping".

Respondents also noted that since childhood they had heard that girls should be feminine, beautiful; and the task of a man is to be rich. The girl must find her prince and marry him. The fact that women should not grow professionally and earn less than their husbands. Thus, we see that from a childhood a stereotype is built where a woman is a passive addictive being whose main purpose is to marry a man. And its professional growth and financial independence are not considered as a priority at all.

In addition, students (women) met with stereotyped beliefs that women do not have a place in politics, business.

Respondents also pointed out, as an example of gender discrimination, the situation with the rights of women in Islamic countries (for example, a ban on driving in some countries of the East). 
Some respondents cited historical examples of gender discrimination, in particular, the example of Antiquity, when the woman in fact did not have any rights.

Answering the question "Have you shown discrimination against others?" Respondents distributed as follows: 15 respondents (29\%), 36 students (71\%) negatively responded (Fig. 3).

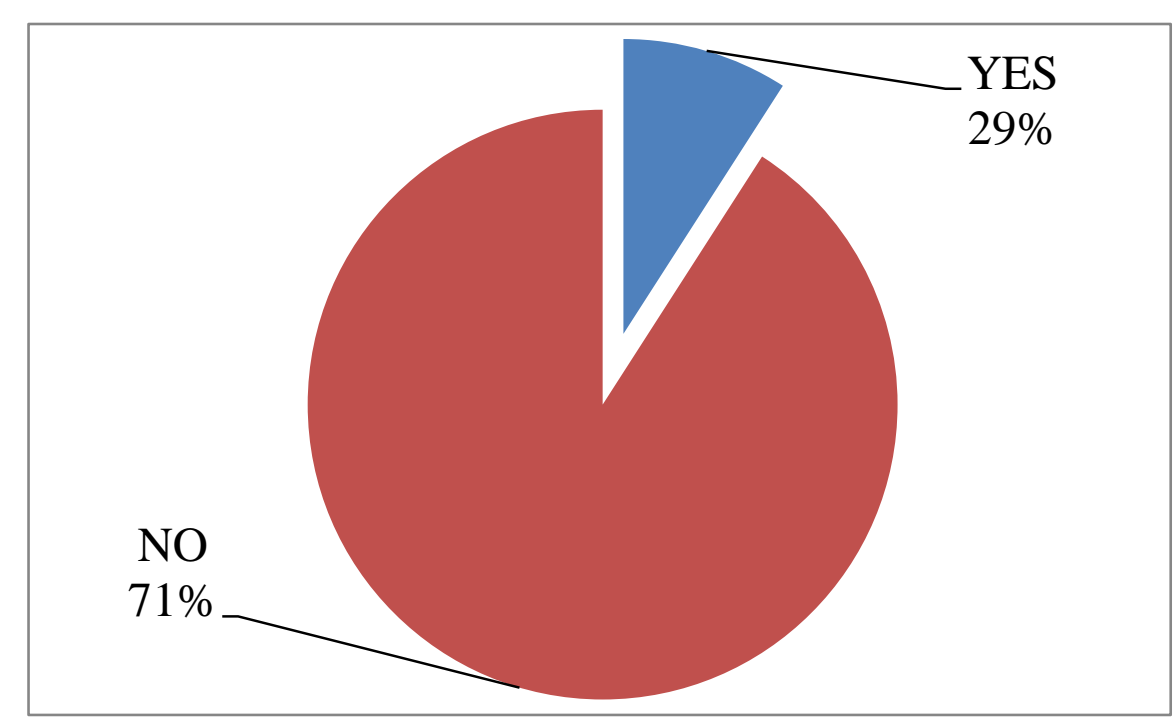

Fig. 3. Distribution of respondents by question, whether they showed gender discrimination to others

The following examples illustrate the discrimination of young people. So, the student noted that at work she sent to pick up a certain product of men, and to engage in documents appointed women.

On the part of male representatives, an example was presented (which had a negative connotation) about meeting with representatives of the feminist movement: "they met "totalitarian human rights activists" more often".

Some respondents indicated that they did not manifest external manifestations of discrimination, but "inside themselves" felt, for example, contempt for a man who behaved too "feminine". This remark brings us to an understanding that the absence of a demonstration, the manifestation of discriminatory actions, does not mean the absence of discriminatory stereotypes.

The most important thing in this situation is the subsequent actions of the subject: what he/she will do with his convictions. A possible way, 
when a person, based on the reflection of himself/herself, his/her life experience, information obtained from open sources can reach the conclusion about the "perniciousness" of imposed stereotypes. It will try to rethink them and change them. Here the vital activity of the subject must take place.

In another deployment of events: the reflection is low, a person does not want to meet the experience of another person and returns to a simpler level of functioning - to stereotypical representations. And for such a deployment of events, this in the future may lead to open discriminatory manifestations.

In addition to gender discrimination, students identified their expectations as to what should be done by representatives of another gender, that is, what they were supposed to show by sexually modeled behavior. And if this behavior did not fit into the commonly accepted option, young people felt "somewhat confused" and "annoying".

In terms of gender discrimination, young people identified the following examples. In particular, they (as representatives of the "strong sex") should give way to women in public transport. Of the 14 boys, 5 respondents turned their attention to it $(36 \%)$.

Students, meanwhile, described as an example of discrimination that only men are liable for military service to Ukraine (for women, service in the army is not compulsory). Two respondents from 14 boys (21\%) focused on this.

One student noted that he sometimes discriminates in the form of irony in relation to himself: "I am a man, I have to work at a factory". In this example, we see that with humor, a young man tries to overcome stereotypes and go beyond its limits.

Also, discrimination against men was noted by boys for the need to pay their bills for "their girlfriend" (in cinema, cafes, travels). 4 respondents drew attention to this (29\%). This result emphasizes once again the importance of women's financial independence from her husband.

One of the boy mentioned the following example of discrimination: "I had long hair for several years, I received mockery and harassment from both young people and adults".

Answers to the question "Would you like to receive more information about gender discrimination?". The respondents answered the following distribution: 43 (88\%) wrote that they were interested in this topic and they 
would like to receive additional information, 6 students (12\%) said that they do not want to receive additional information. Such a division allows us to talk about the high level of relevance of the issue of gender-based discrimination. We see that young people seek to broaden their knowledge of understanding discrimination, its manifestations and possible prevention in Ukrainian society.

Consequently, the chosen topic of research is relevant and requires a detailed study. The obtained results give grounds for talking about the need to highlight the topic of gender discrimination, especially in the psychological context.

We believe that the study of discrimination should be based on the work done by scholars from around the world. It should be emphasized that genderbased discrimination should be investigated by representatives of various scientific fields in order to enable them to understand the origins of this phenomenon. In particular, this problem should be studied by psychologists, sociologists, anthropologists, historians.

An understanding of the origins of discrimination in the context of women's financial and economic dependence on men is also important. Therefore, the study of this issue would be incomplete without representatives of economic science. The formation of independent, successful women who have the right to influence socially meaningful decisions is impossible without involving women in the political sphere, and therefore one can speak about the role of political science in solving gender discrimination.

As we see, the issue of gender-based discrimination is broad and multilevel. It requires considerable efforts from scholars and public representatives to study it and outline ways to overcome gender-based discrimination.

\section{CONCLUSIONS}

As a result of the theoretical and empirical research, we have clarified the concept of "gender", "gender identification", "gender discrimination"; the history of the emergence and formation of these phenomena is presented. The theoretical analysis made it possible to identify the countries that were the first to identify the priority of combating the manifestations of gender discrimination.

In the context of contemporary Ukrainian society, the study of genderbased discrimination needs more attention. Particular importance is given 
to the desire of young people to step outside the discriminatory space and their desire to go their own way, not through stereotypes. The primary focus in this context is educational activity that helps young people to understand the perniciousness of stereotypes and gives the feeling that everyone has the right to be and can determine the priorities of their personal growth for themselves.

The obtained results made it possible to determine the peculiarities of understanding the gender discrimination of the student youth of Ukraine. It is clear that the study procedure allowed to identify only general trends in the issue of gender-based discrimination. Our scholarly search in the future will include a deeper psychological analysis of the attitude of young people towards gender inequalities and discrimination.

\section{SUMMARY}

This article is devoted to the study of gender-based discrimination in the context of the view of this phenomenon by student youth. Gender discrimination is a phenomenon that arose a century ago and which, unfortunately, continues to exist. In the modern world, the most attention to this problem is paid to such countries as: USA, Canada, Sweden and other countries of Western Europe. In Ukraine, research in this area takes place, but needs a more practical component: the theory should be implemented in practice.

That is why this article raises the question of asking young people for information on gender discrimination. In addition, the coverage of gender discrimination raises questions about a new perspective on the role of women and men in building family relationships. It is very important for young people.

The research revealed the specificity of gender discrimination on the part of student youth. It has shown that students associate this type of discrimination with human rights violations, with the pressure of society on a person, which limits her/his freedom to be what the person wants.

The survey showed a significant percentage of young people who have been exposed to gender discrimination in their lives: in daily and professional communication.

The obtained results actualize the question that modern youth tends to change the social stereotypes that restrict the choice of personality. These issues are particularly acute in the context of gender-based discrimination. 
Because, whatever the person whoever she was, would be forced to face social expectations about his/her gender.

Such expectations often have too much impact on human behavior and its ability to make informed and independent choices about oneself and in their livelihoods. And if the young person does not know and does not know that any phenomenon faced by a person has to undergo a certain level of critical reflection in order to understand the difference between what "I feel" (personal level) and those "so it should be" (social expectations and stereotypes), it's almost impossible to get out of stereotypes.

The ability to implement active psychological work (reflection) at the level of the individual will allow a person to identify "white spots" of his/her ignorance and expand the scope of his understanding. Such "extended" awareness allows you to go beyond the established stereotyped framework and look at yourself and the world in a different way. And, therefore, it provides an opportunity to take steps to overcome discrimination, including gender-based discrimination.

\section{REFERENCES}

1. Бем С. Линзы гендера: Трансформация взглядов на проблему неравенства полов / [пер. с англ.]. М.: «Российская политическая энциклопедия» (РОССПЭН), 2004. 336 с.

2. Виртосу I. Гендерна дискримінація: Як не наступити на граблі старими мозолями? URL: https://humanrights.org.ua/material/gendernajia_ diskriminacijia_kak_ne_nastupit_na_grabli_starymi_mozoljiami (дата звернення 04.05.2019).

3. Говорун Т.В., Кікінежді О.М. Гендерний дискурс в психологічній науці та педагогічній практиці. Психологічний часопис : збірник наукових праць / за ред. С.Д. Максименко. Київ: Інститут психології імені Г. С. Костюка Національної академії педагогічних наук України. № 1 (3). 2016, 200 с.

4. Говорун Т.В., Кікінежді О.М. Стать та сексуальність: психологічний ракурс. Тернопіль: Навчальна книга - Богдан, 1999. $343 \mathrm{c}$.

5. Кембриджський словник URL: https://dictionary.cambridge.org/ (дата звернення 01.05.2019). 
6. Мак-Вильямс Н. Психоаналитическая диагностика: Понимание структуры личности в клиническом процессе. М.: Класс, 1998. $480 \mathrm{c}$.

7. Малкина-Пых И.Г. Справочник практического психолога. М.: Изд-во Эксмо, 2007. 784 с.

8. Ожегов С.И., Шведова Н.Ю. Толковый словарь русского языка (А-Д) Издательство “Азъ”, 1992.

9. Перлз Ф. Практика гештальттерапии. М.: Институт Общегуманитарных Исследований, 2005. 480 с.

10. Словник украӥнської мови : [в 11-ти т.] / [ред. кол.: І.К. Білодід (гол.) та ін.]. Київ: Наукова думка, 1970-1980. Т.2: Г-Ж / ред. тому: П.П. Доценко, Л.А. Юрчук. 1971. 550 с.

11. Шевченко 3.В. Словник гендерних термінів. Черкаси: видавець Чабаненко Ю., 2016. URL: http://a-z-gender.net/ua/\% D2\%91ender.html (дата звернення 03.05.2019).

12. Challenging gender discrimination: a how-to guide. URL: https://plan-international.org/girls-get-equal/calling-out-discrimination (дата звернення 30.04.2019).

13. Mead Margaret. Sex and Temperament in Three Primitive Societies $\left(1^{\text {st }}\right.$ Perennial ed. $)$. New York: Perennial an impr. of HarperCollins Publ., 2003. 352 p.

14. Steiner C. Scripts People Live: Transactional Analysis of Life Scripts. Grow Press: New York, 1990. 332 p.

Information about author: Kostina T. 0.

Candidate of Psychological Sciences, Associate Professor at the Department of Psychology and Pedagogy of the V. I. Vernadsky Taurida National University 33, Ivana Kydri str., Kyiv, 01042, Ukraine 


\section{RECREATIONAL APPROACH TO REALIZATION OF SOCIAL WORK PRINCIPLES}

\section{Kostyuchenko O. V.}

\section{INTRODUCTION}

The complexity and conflicting development of social relationships in the Ukraine require the new integrated knowledge of the person's life in dynamic social area and needed means of social help for full realization of his/her abilities in any possible situations. The prioritized themes for analysis in social-liberal sciences are inconsistent social process and a specific individual who experiences this process in his/her daily life. The reactions on experience are not identical for each person and sometimes they cause the active concern of society. One of the forms of concern is a social help.

The National Association of Social Workers of USA developed the full description of the essence of social work. It is a professional activity for giving help to individuals, groups or societies, strengthening or restoration of their abilities for social life and providing favourable conditions for attaining these goals. In the context of our analysis we pay attention on the process of social work that is realized on the micro-level (among others such as meso-level and macro-level) of society development. The latter is based on the interactions and interrelationships between individual and society. The adaptive-development theory and practice of social work is a basis for our studies ${ }^{1}$.

The responsibility, skill, creativity of each professional in any sphere and in social work particularly not only provide the progress of society but become the guarantee of the favourable existence of a person, and protect him/her from the loss of job, stresses and poverty. An issue of searching of the ways for success, contented, decent, and prosperous life is relevant in any sphere and particularly in area of social security, benefits, help for different categories of population which are carried out through such functions as: organizational (arrangement of particular

\footnotetext{
1 Лукашевич М.П., Мигович І.І. Теорія і методи соціальної роботи. 2-е вид., доп. І випр. К.: МАУП, 2003. $168 \mathrm{c}$.
} 
activities, influence on the content of leisure, assistance in an employment, career guidance, adaptation and so on); prognostic (programming and forecasting of social development process of district and household, the activities of the specific and various institutions, which participate in social formation of person); preventive-prophylactic and social-therapeutic (foresight and prevention, and overcoming the negative impact in social-legal, juridical and psychological areas and so on); organizational-communicative (recruiting of assistants-volunteers and people of the district for social work and recreation, business and personal contacts, storage of information and arrangement of contacts between various social institutions in the work with clients); protectivesafeguarding (the application of set of legal norms for protection of client's rights and interests, the assistance in enforcing of the governmental coercive measures and invoking legal responsibility of the persons who intentionally and unintentionally commit unlawful acts).

The applied goal of this publication is to illuminate the ways of recreational approach for effective addressing of the problem solution in professional activities of social worker and teacher. The modern living conditions and professional activities are characterized by heavy a mental stress, a chronic overstrain, a heightened level of anxiety, emotional and informational stresses, and by other etiological factors. Its actions cause in most cases overstrain and asthenia of adaptation mechanism, exhaustion of body functional reserves, reducing the ability to work that require more carefully weighted demands for development and implementation of methods and techniques, resources and conditions for renewal and restoration of human adaptive mechanisms. Therefore the psychotechnologies are developed that assist in better understanding of personal inner light, controlling of one's own desires and actions, developing and making the most of the essential potential.

The psychological backup of social pedagogue's and worker's professional activities will contribute to: 1) performance of professional plans and aspirations; 2) discovering one's own and his/her client's abilities and reserves; 3) highlighting the aspects of vitality - his/her motivational and operational spheres; 4) clarifying criteria, levels, periods, factors that support or impede a worker or a client elucidating the stages toward resolution of the on-going problem; 5) studying the personal past 
and present experience, clarifying the future; 6) correlation between personal competence and inconsistent challenges of society and so on.

This publication updates the issue of developing the social pedagogues and workers professional competence. The article primarily directs to elucidating the theoretical, methodological and psychological aspects of their professional activities in context of holistic recreational approach with the purpose of personality restoration in physical, psychological (intellectual and emotional), professional, cultural, spiritual aspects. The main task is to point out at a wide range of opportunities for social workers in sphere of their recreationally directed professional activities that brings to fullness the creative and personal potentials when such opportunities are continually expanded. That expansion of opportunities increases the level of communicative skills and creativity, predestines the multifaceted influence of the experience on the professional skills and the creative development of a person, efficiently and inventively discovers possibilities and abilities which are needed in order to gain and practice required knowledge, skills, and experience for analysis of specific business, social-psychological situations and events.

\section{The recreative and adaptative component of social work}

It is important to understand that the socialization occurs without particular deviations if conditions created by society ensure effective socialization and/or a person's capability meets a norm.

Such modern models of socialization as psychoanalytic or "Personal control" (S. Freud), "Role training" (T. Parsons), "Social learning" (G. Dolat, B. Skinner, etc.), "Interpersonal communication" (C. Coolley, G. Mead, etc.), "Cognitive" (J. Piaget, A. Maslow, etc.), and "Evolutionary" (E. Erikson) consider socialization as a process of human interaction with the surrounding community.

These are a process of integrating of an individual into a social system and adapting him to new social conditions and a process of becoming a personality as a social being, whereby various relationships of the individual with society are established., orientation, values and norms are developed, personality traits evolve, activity and integrity of the person are formed, social experience is accumulated, accumulated by humanity for the entire period of its development. The orientation, values, and norms are learnt. Personal characteristics are developed, activity and integrity of the 
personality are formed, and social experience accumulated by humanity for the entire period of its development is acquired.

A moment of dynamic equilibrium, harmonization of norms and traditions of the environment and human behavior occurs at a certain level of socialization of the interaction of personality with the environment. The achieved level of socialization allows an individual to operate naturally in a changed environment relying on a new higher level of his/her adaptive capacity. This shows the dialectic interaction of the functions of socialization and adaptation. However, when the social conditions of socialization or the physical, mental or spiritual health of a person deviate from the necessary level for an effective socialization socialization occurs with complications. So, a person and even some social groups are involved into difficult life situations and require social help from the state, its institutes or other subjects of a specific activity which is called social work.

An individual requires professional social help in order to adapt to crisis situation in life and overcoming the stress. Social work allowes the necessary social correction of the deviation (or support) of the individual adaptive mechanism of a client and, if it is necessary, facilitating adaptation of the real life situation.

Regarding this issue the following terms are used in the scientific literature: "social policy", "social work", "social insurance", "social services", "social support" and "social assistance" (S. Belicheva, V. Bocharova, S. Hrihoreva, I. Zimnya, A. Kozlova, V. Kolkova, P. Pavlenok, A. Banova, A. Sorvina, E. Smirnova, L. Topchiy, M. Firsova, E. Holostova, B. Shapiro, T. Selyaha, N. Shmilova, N. Shchukina, V. Yarska etc.). The Ukrainian scholars (O. Horpinich, N. Ivanova, V. Kolyadenko, A. Silenko etc.) focus on applied aspects of social work.

As used in this study the interpretation of social work is accepted as "a type of social activity aimed at the harmonization of personal and social relations by means of care assistance to individuals, groups of people and communities experiencing difficulties in social functioning by protection, support, correction and rehabilitation, and changing or reforming of certain elements of the social system", , which is social assistance (L. Stefan, I. Prokopenko, V. Lozova) in the relations and interaction of society,

\footnotetext{
${ }^{2}$ Социальная работа / под ред. В.И. Курбатова. 2-е изд. Рн/Д.: Феникс, 2003. С. 7.
} 
aimed at optimizing of the existence of the individual, the technology of the formation, implementation and rehabilitation of a human vital forces.

Thus, the Austrian Academy of Social Work suggests considering social work as a specific form of help to people from a society in meeting their social needs and solving conflict situations caused by individual or social reasons. One of the important organizational principles of social work is the inducement of a person to a conscious, interested expression of activity in the realization of his/her own energy, abilities, moral and volitional potential for the achievement of a certain goal. It is understood that the source of the motive force in some sort of activity is not the interests and needs of a person by itself and the level of their satisfaction.

The integrity and comprehensiveness of solution of social problems is arranged by complexity in social work when internal and external conditions, factors, states in interconnection and mutual interactions are taken into account. Social work has a complex integrated nature realizing its creative potential through numerous functions. The main functions are epistemological, organizational and educational, regulatory and preventive, information and communication, socio-integration, analytical and predictive.

The complex-oriented approach (humanistic, existential, psychodynamic, systemic-ecological, role-based, social-pedagogical, cognitive theory) to social work is based on a recreational basis by optimizing of the client's own efforts to use his personal and social resources in influence to the situation and maintain balance between the client and the environment.

According to the declared subject, we will focus on the recreational approach as a synthesis of different theories and practices. The problems that are devoted to the theory and practice of recreation are discussed quite actively in current science. As for the definitions of recreation, the problem lies not so much in the existence of different approaches to the interpretation of this concept as in the identification of the last with the other concepts - "rest", "entertainment", "leisure", "restoration of forces", "recovery", etc. ${ }^{3}$. We read at the Latin-Ukrainian dictionary ${ }^{4}$ re-creare, creo, avi, atum - 1) reproduce, recover, renew (aliquid); 2) remake, convert (vitam); 3) restore, support, refresh (vires)// strengthen, cheer up (afflictum

\footnotetext{
${ }^{3}$ Кант И. Соч. в 6 томах. Т.6. М., 1966. 365 с.;

Кірсанов В.В. Основні напрями дослідження рекреації. Вісник книжкової палати. 2004. № 10. С. $19-23$.

4 Латинсько-український словник: 10 тисяч найуживаніших латинських слів 3 максимальним відтворенням їхніх значень українською мовою. Київ : Українські пропілеї, 1998. С. 548.
} 
animum; mentem); 4) se, aбo pass. recreari - retreat (ex or a timere); to recover (e morbo); revive, regain strength (res publica recreatur); to rest, recover (litteris sustentari et recreari). Therefore, the definition of the recreation is rather vague. The ability to occure at any time, has an active character, is based on a voluntary and self-basis, and aimed at healing, may have a cognitive nature and be a means of self-affirmation are characterised as the recreation.

The recreation is compensation not only for overloads, but also for underloading. It should be noted that the compensative nature of recreational activity gives an opportunity to comprehend deeper and further grasp its connection with creativity and self-realization.

This is not just about compensation in the physical, mental, intellectual, but also about re-creativity (re-creare) in the large sense of the word, which finds its manifestation in cultural, spiritual, existential activity, in the realization of abilities, aspirations of the person, its the need for self-expression (revealing essential forces), self-improvement, creative development, etc.

Assume that the recreation is a process and means of recreation of a person in physical, mental, cultural and spiritual aspects then the psychological and pedagogical supplying of the recreation can be considered within each of these aspects. At the same time, the fundamental is reproduction, recreation, and not just restoration, because recreativeness is connected also with the realization of potentials, the essential forces of the individual - desire of the individual to reproduce him to the level of the ideal "I-image".

Special attention should be paid in social work to the processes of creativity and the disclosure of creative potential of the individual as the most important condition for its self-realization when considering various psychological and pedagogical fields of study of recreation. Its selfrealization is especially important in the context of the necessity to reorient of a person from the passive-consumer to the creative activities. The creative activity is connected with meaningful components of human life and is a necessary condition for finding meaning of life.

At present, the actualization of social work is due to such considerable interferences as today's development and the complication of the phenomenal phenomenon of the world. One of the indicators of adaptation to it is the state of harmony which from the subjective prospect is the 
perception and experience of well-being in its various aspects ${ }^{5}$ : spiritual (feeling of involvement in the spiritual culture of society, awareness of the possibility of being involved in the wealth of spiritual culture), social (the satisfaction of the individual with his/her own social status and the actual state of society to which the person attributes to himself, satisfaction with interpersonal connections and status in the microsocial environment); the salutary (physical) (good physical well-being, physical comfort, a sense of health, satisfaction with physical tone) and the most relevant for our research psychological (mental comfort associated with the coherence of mental processes and functions, a sense of integrity, internal balance. Its cognitive component implies the integrity, relative inconsistency of subjectivity the world views, the understanding of the current situation of life, and the emotional component - an experience that combines feelings due to the success of the subject in a particular areas of activity) ${ }^{6}$.

The statute of the World Health Organization (WHO) states "Health is not only the absence of a disease or physical defects, but full physical, mental and social well-being"7. This notion of health indicates a close psychosomatic connection of a person with many internal and external factors. Life-sustaining activity as a component of a living system is provided at different, but interrelated levels of functioning.

It can be distinguished conditionally three very specific levels of consideration: biological, psychological and social. Human health has features of manifestation with each of them. Regarding the healing, Recreational issues can be interpreted from the perspective of this definition of health.

The concept of psychological health that can sometimes get close to the concept of spiritual or mental health of a person is defined as a higher level of demonstration of intelligence, feelings, self-regulation ${ }^{8}$. Mental health is a state of mental well-being, which is characterized by the absence of painful mental manifestations and provides for the regulation of behavior that is adequate to the environment. This concept includes medical and psychological aspects, social, group norms and values that regulate the spiritual life of a person.

\footnotetext{
${ }^{5}$ Ахмедов Т.Н., Жидко М.Е. Психотерапия в особых состояниях сознания: История, теория, практика. Харьков: Фолио, М.: АСТ, 2000. 768 с.

6 Психологічне забезпечення психічного і фізичного здоров'я / За заг. ред. М.С. Корольчука. К.: ШКОС, 2002. 296 с.

${ }^{7}$ Никифоров Г.С. Психология здоровья. СПб: Речь, 2002. 256 с.

${ }^{8}$ Моляко В.О. Психологічна теорія творчості. Наукові записки Інституту психології ім. Г.С. Костюка АПН Украӥни. К., Нора-Прінт, 2002. Вип. 22. 350 с.
} 
Perception which manifests itself in the adequacy of subjective images that reflect objects of reality and the nature of reactions to external stimulating substances plays a crucial role in a set of criteria that determine the norm of mental health such as the significance of life events; the level of maturity corresponding to the age, emotional-volitional, and cognitive sphere of the individual; adequacy in microsocial relations; the ability to self-regulate behavior, intelligent planning of life goals, and activity in its achievement.

Social health is defined as an adequate perception of social reality, interest in the surroundings, adaptation to the physical and social environment, focus on a socially useful business, a culture of consumption, altruism, empathy, responsibility to others, selflessness, and behavioral democracy.

The question of the criteria for assessing the mental health problem is key. The most often separated criteria for mental health are mental balance, which can characterize the features of the functioning of the mental sphere of man on various sides - cognitive, emotional, volitional; the ability to logically process information; critical thinking; creativity; discipline of reason, which certainly can not be achieved without maximum approximation of subjective images to objects of reality that they reflect (the adequacy of mental reflection); adequate perception of oneself and the world, etc. ${ }^{9}$.

The adaptability to objective conditions depends on the level of mental equilibrium (V. Myasishchev). The equilibrium of the person and the adequacy of his/her reactions to external influences are of a great importance in relation to the distinction between norm and pathology. The only mentally healthy (equable) person is a manifestation of comparatively persistent behavior and the adequacy of its external conditions and the high individual adaptability of an organism to the usual changes of the environment, the ability to maintain the usual comfortable feeling of selfawareness, morphofunctional preservation of organs and systems. This criterion is closely related to the other two - the adequacy of the organization of the psyche and its adaptive capabilities in which the perceptual components are activated ${ }^{10}$.

\footnotetext{
${ }^{9}$ Никифоров Г.С. Психология здоровья. СПб: Речь, 2002. 256 с.;

Розов В.І. Адаптивні антистресові психотехнології. К.: Кондор, 2005. 278 с.;

Сандомирский М.Е. Защита от стресса. Физиологически-ориентированный подход к решению психологических проблем (Метод РЕТРИ). М.: Из-во Института Психотерапии, 2001. 336 с.

${ }_{10}^{10}$ Мясищев В.Н. Психотерапевтическая энциклопедия. СПб.: Питер, 2000. С. 394-195.
} 
Developing a system view of adaptation and self-regulation, Y. Aleksandrovskii considers adaptability as the result of an integrated self-directed system consisting of subsystems. There are search, perception and processing of information; social psychological contacts; regulation of sleep and not sleep; emotional response; endocrine-humoral regulation which are in mutual compensation and form an individual adaptation barrier. "The presence of mechanisms of conscious self-regulation is essential in this system" $"$.

Thus, based on the analysis of the scientific literature, adaptation can be interpreted as a phenomenon that has three general aspects of consideration in the context of recreation ${ }^{12}$.

The first aspect focuses on the characteristics of the process of adaptation to the new environment. In this context, the systemic aspect of considering the adaptation process becomes important, where the environment and subject of the adaptation process are considered as multilevel systems. The problem of adaptation was studied in physiology at a specific scientific level (L. Abolin, P. Anokhin, V. Petrovsky, S. Kriagzhde, H. Selie, N. Yakovlev, etc.); psychology [B. Ananiev, B. Asmolov, B. Benediktov, I. Boyko, L. Vygotsky, A. Rean, A. Petrovsky, P. Prosetsky, V. Semichenko, A. Maslow, etc.); pedagogy, theory and methodology of sports training (S. Voitsekhovsky, N. Volkov, V. Keller, P. Lesgaft, V. Platonov, etc.); Sociology and Culturology [A. Andreyeva, A. Bandura, V. Vasiliev, A. Georgievsky, I. Miloslavova, H. Tsaregorodtsev, B. Parigin, etc.).

The second aspect of the study of adaptation focuses on the balance of a subject and an environment in the integrated space of the "adaptation space". This balance allows us to study the various characteristics of the environment and the organism from the prospect their equilibrium that is very important for determining the nature of the specific problem of adaptation.

For instance, A. Heorgievsky emphasized the adaptation process as a certain form of the reflected interaction of the external and internal environment with a tendency to establish a dynamic equilibrium.

\footnotetext{
${ }^{11}$ Александровский Ю.А. Состояния психической дезадаптации и их компенсация. М.: Наука, 1976. 272 c.

${ }^{12}$ Костюченко О.В. Основні напрями психологічного дослідження адаптації та рекреації у контексті психічного здоров'я. Актуальні проблеми психологї. Т. 12. Вип. 10. Житомир: Вид-во ЖДУ ім. І. Франка, 2010. С. $154-161$.
} 
N. Melnikova notes the adaptation tends to a certain balance, starting with the imbalance between the two systems and coordination between them. As a result, there may be changes in both of them.

The focus on new features of the system "organism-environment" refers to the third aspect of the phenomenon of adaptation. This moment is important, given the fact that the result of the adaptation process can not be studied only as a fact of life activity, but also it is characterized by qualitative changes in the properties of the subject and the circumstance. B. Lomov considered adaptation as the interaction of "sub-system" and "megasystem" contradictions that exist both externally and internally ${ }^{13}$.

Another important issue for the studied problem is that the person in the adaptation process is considered not only as an object of influence from the side of the environment, but as an active system. This is a subject that seeks to change the environment, strives for self-assertion and self-realization, and in the process of adaptation acquires new cultural, social qualities, value orientations, knowledge, skills, forming their own perception of the world, etc. Thus, it becomes clear the meaning of the study, that the subject's purpose is his/her life goals.

Considering the role of creativity in adapting a person to a constantly changing world, V. Molyako proposes to take into account the "creativetransforming" function of consciousness, "the strategic organization of consciousness that allows regulate the content of the stream of consciousness. This allows finding specific systems in chaos design them and build, focusing also on objective indicators, set by all those requirements that exist in reality" $" 14$. These are strategies that allow you to organize the "chaos of thinking", find ways and means of ordering that will solve new tasks, complete the creative process by achieving balance through harmonization.

The image of the world which is formed in accordance with the giftedness of the individual is considered as its systematic formation which coordinates, regulates and stimulates creative activity. This is a peculiar measure of genetically and experimentally-conditioned human ability to adapt to life.

\footnotetext{
13 Ломов Б.Ф. Методологические и теоретические проблемы психологии. М.: Наука, 1984. 444 с.

14 Моляко В.А. Проблемы психологии творчества и разработка похода к изучению одаренности. Вопросы психологии. 1994. № 5. С. 86-95.
} 


\section{The recreational psych-technologies as tools of social work}

We note that certain psychological and pedagogical goals of social work are realized through appropriate recreational programs, measures and actions. At the same time different purposes require different programs, measures, actions for their realization. Since they often entail significant costs (financial, human, time, logistic burden, and so on) there is a need to create a jointed methodology for the development of complex, multipurpose programs that promote the achievement of several aims and in the same time save financial, human, time, logistical resources.

The general principle of solving this problem is the integration of two or more functional systems that have different goals into a single integrative polyfunctional (multi-purpose) system. We understand multifunctionality as an output principle of integrative model construction for theoretical justification and practical implementation of programs, events, psychologically oriented actions such as developing, formative, mobilizing, recreational, image creating etc. Thus, organization of events in a group promotes self-improvement based on the experience of group members, full self-expression, personality development and building the system of interpersonal relationship and world-view.

First of all, the development and implementation of multi-purpose programmes of various types suggest that they are to be designed at the level of theoretical integral models. The practical result of such modelling is that on the basis of a particular model of the programme becomes possible to arrange a variety of multi-purpose actions and events. Probably the most complex and the least developed questions are scientific and methodological justification of methods of organized recreational activities, and their professional application. It is necessary to take into account the fact that whatever methods we use we definitely leave an impression on the inner world of a person. Effective methods suggest not only the analysis of psychological and pedagogical essence of work with people of different ages but also a profound justification of methods and forms of their implementation.

The category of recreational technologies in social work in our edition is a complex integrative system that includes an ordered number of operations and actions. They define recreational purposes and provide meaning, informational, substantive and procedural aspects aimed at the restoration of the optimal psycho-emotional condition, learning, gaining 
skills and the formation of personal qualities that answer the pedagogical and psychological goals of training the target audience in the social work system. The structural components of such a system are: the purpose, content, process organization, participants of a process, technology specialist, system engineering complexes of psycho-pedagogical interaction, diagnostics of indicators before the implementation of psychotechnologies and the results of the recreational process.

Now we consider in more detail some of the structural components of the recreational program. Thus, the purpose of recreational psychotechnologies is the formation of a positive triple image "I-World-Others"; awareness of his/her own reserves and opportunities for creative selfrealization in this three ones. There is a short list of indications for the use of recreational technologies in order to fulfil the tasks. It can be following: lack of interest and indifference to the world around; reduction of working capacity; excessive emotionality; psycho-emotional stress; anxiety; the difficulties of emotional development; actual stress; decrease of emotional tonus; impulsive emotional reactions; low level of self-perception; lack of self-confidence; the need in communication; the need in communication with other people using the results of his/her labour; the development of creative ability; cognitive needs, striving for perceiving the world through its symbolization in a special form, the design of the world in the form of drawings, sculptures, tales, stories, choreography, singing etc.

For this purpose there is a need to create a harmonious space for recreational activities, based on the knowledge of exterior design and its particular impact. The tasks for achieving the goal can be following: overcoming uncertainty in communication; development of independence; formation of the ability to defend his/her position; awareness and disclosure of his/her own possibilities and abilities; promoting creative self-expression, and so on. These criteria for selecting a target audience are also signs that indicate the necessity to attend the specific events of recreational programme, and this is a kind of installation diagnostics. The age and sex of the group should be heterogeneous based on three main criteria: demographic (age, gender, education), problematic (symptoms, psychological diagnosis), personal (character, range of interests).

The organization and implementation of the recreational programme should be accomplished taking into consideration the inter-individual differences between subjects of the recreational activities, and in particular 
the following: age and personality development; age and education; psycho-physiological, behavioural and role differences between men and women (D. Kolesov, S. Kudinov, A. Anastasi, A. Koni), etc.

When we distinguish the known levels of psychotechnics ${ }^{15}$, we prefer the following: bioenergetic (regenerative nutrition, autophytic regulation, physical and motional activity), psycho-physiological (psycho-technology of adaptive bio control with biological feedback, progressive muscle relaxation, antistress relaxation, autogenic training, systematic desensitization; technique of breathing, body-oriented techniques, meditation), cognitive (neuro-linguistic programming (NLP); Design Human Engineering (DHE); cognitive therapy (A. Beck) and rationalemotive technique (A. Elisa), personal (psycho-synthesis of subpersonalities R. Assagioli; Gestalt technique for the awareness of needs; assertive) and relational (W. Glasser reality therapy, transactional analysis E. Berne, behavioural approach D. Volpe and A. Lazarus) etc. The emphasis is made on the fact that each of the recreational methods at any level makes a comprehensive impact on the physiological, emotional, intellectual, personal and social spheres of the individual, on the formation of his/her value orientations, moral, volitional and creative sphere bringing to fullness the adaptive and creative potentials. Therefore, to ascribe to any techniques or methods the level of reliability is rather arbitrary. It is caused by convenience of such classification that simplifies establishing the expediency of their use in the development of poly-functional recreational and educational programmes.

Now the effective psychological interactive forms and methods are in focus of our discussion. It is expedient to use them in social and psychological assistance to clients:

- psychogymnastics of cognitive activity is an effective method of optimizing the cognitive, affective and social-perceptual sphere of the individual. It focuses on the "language body" and spatial-temporal characteristic of communication. The method is aimed at solving the tasks of group psycho-correction: establishing a contact, removing the stress, tracking feedback, etc. ${ }^{16}$.

\footnotetext{
${ }^{15}$ Бурлачук Л.Ф., Кочарян А.С., Жидко М.Е. Психотерапия. Спб.: Питер, 2003. 480 с.;

Рудестам К. Групповая психотерапия. Психокорекционные группы: теория и практика. М.: Прогресс, 1990. 368 c.;

Ялом И. Теория и практика групповой психотерапии. СПб: Питер, 2000. 640 с.

16 Большаков В.Ю. Психотренинг. Социодинамика, упражнения, игры. СПб: Социальнопсихологический центр, 1996. 380 с.;
} 
- the use of graphic techniques, including drawing (Ricci, Cook, Preyer, Orshansky, Sally, Bechterev, Bakushinsky, Stern, Bühler, Arnheim, Muhina, Allan, Ponomarev, Furth, Dileo, Melik-Pashayev, Romenets, etc.) is a creative act that allows one to feel and understand oneself, freely express ones thoughts and feelings, be released from conflicts and anxieties, develop empathy, sensory-motor coordination;

- modern trends and methods of art therapy: landscaped is associated with the search and use of natural and man-made objects as the main material and means of creative activity; mask therapy is based on externalizing deep processes of a person into the mask. It helps to discover displaced and blocked emotions in order to release inter freedom; metaphorical ball is used to create successful communication; neurographics helps to express the experiences, conflicts, problems, positive goals using simple geometric figures and lines; beeswax therapy (it is a material that influence emotions) of anger, aggression, fear, anxiety, reticence; play dough therapy helps to reduce psycho-emotional stress; textile art therapy assists to find an outlet for inter feelings through the various pictures made on textile which contributes to the psychological changes related to ecology; therapeutic needle felting is the use of wool as a material for art and images; film therapy is a system of methods for working with reactions received by the client before, during and after watching a certain audio-visual products; photo-therapy is taking shots and/or reaction of a client on photographic images that is accompanied by discussion and various types of creative activities; food-art is usage the potential of food influence in order to meet basic human needs such as his/her relaxation and refreshing his/her inter resource;

- testing differs significantly from the usual psychological testing, first of all, that it should be taken as short as possible and be interesting to the participants. It is used to test participants' knowledge and skills, to identify learning motivation, to find out the effectiveness of certain exercises, methods, and activities in general. Of course, the uncomplicated test is an answering on multiple-choice questions by participants (e.g., "Non-existent animal", "Three desires", "Invisible hat", "Game room", "Finishing the image", "Questions about pictures", "A story based on pictures", "Pictogram", "Fantastic hypotheses", "Telling fairy tales", "Imagine that...", "If I...", etc.);

\footnotetext{
Технологии социально-психологических тренингов. Консорциума «Социальное здоровье России», 2001. 208 с.
} 
- bible-correction is a cultural practice of book selection for recreational purposes. It depends to a large extent on education, cultural needs of a person and also on his/her present emotional state;

- various forms of communication for stimulating creative-perceptual activities are used. For example: exercises for promoting acquaintance of participants in group interaction; psycho-technical games (L. Abramyan, A. Varga, I. Vygodskaya, A. Zakharov, A. Spivakovskaya, and al.), games: relaxation, communication, jokes, fantasy, developmental; related to kokology; situational and role based; business; role-playing; activitycommunicative, etc. The game purpose is to activate and release the abilities, to use the dormant human mental reserves, the expansion of the repertoire of self-perception and self-expression ${ }^{17}$;

- individual and group creative $\operatorname{tasks}^{18}$ provide almost unlimited possibilities for self-expression and self-realization as the results of creativity, facilitate the process of communication and establishing relationships with other significant people (relatives, peers, etc.);

- Aesthetic development is defined as "the development of the ability to experience various phenomena of reality as beautiful" ${ }^{19}$ by means of aesthetic and artistic (according to P. Jacobson) assessment as a human interaction with the "psycho-artistic" reality which contributes to the creation of a new, mental and spiritual reality ${ }^{20}$ by means of art in general. The main functions of aesthetic development $\operatorname{are}^{21}$ : cognitive, social, valueorientation, social-organizing, semiotic, communicative, hedonistic, aesthetic;

- Creative perception of the world reflected in the works of art and cultural-historical heritage is a complex, multilevel system that solves recreational tasks: the artistic organization of leisure, the integration of cognitive, entertaining and artistic creative function. Information-logical and

\footnotetext{
${ }^{17}$ Большаков В.Ю. Психотренинг. Социодинамика, упражнения, игры. СПб: Социальнопсихологический центр, 1996. 380 с.;

Вачков И.В. Основы группового тренинга. Психотехники. М.: Ось-89, 2001. 224 с.;

Корекційна робота психолога / упоряд. О. Главник. К.: К 66 Шкільний світ, 2002. 112 с.;

Технологии социально-психологических тренингов. М.: Редакционно-издательский центр Консорциума «Социальное здоровье России», 2001. 208 с.

${ }^{18}$ Рекреаційні аспекти активних творчих методів сенсорно-перцептивної активації для дітей підліткового та юнацького віку. Проблеми сучасної психології. Вип.19. Кам'янець-Подільський: Аксіома, 2013. C. 313-323.

${ }^{19}$ Психологический словарь / [под ред. В.П. Зинченко, Б.Г. Мещерякова). 2-е изд. М.: Астрель, 2004. C. 768 .

${ }^{20}$ Костюченко О.В. Художня перцепція в системі рекреації. Актуальні проблеми психологї. К: Фенікс, 2015. Т.ХІІ. Психологія творчості. Вип. 21. Ст. 174-184.

${ }^{21}$ Новиков А.М.. Методология художественной деятельности. М.: Сговес, 2008. 72 с.
} 
emotional-figurative effects are discovered in investigations of the museum educational potentials. The museum is a way for studying the world and it has a great cultural and recreational potentials as well as the ability to create conditions for the visitor's personal development, for his deepening in himself, self-identification, discovering his own place and role in the world.

One of the methods of attracting a museum visitor to active interaction is the game (game-journey, game-study, role-playing game). Such interaction with the museum environment that is organized in the form of a game, leads to a new, qualitative level of more full and deep perception of the documentary material. In this case the museum visitor receives not only the information load but also emotional unloading. In addition, he/she communicates with history not only on the intellectual level but also on the level of personal experience. When art museums is visited with the goal to immerse into an art that "reflects", "educates", "represents", and "calls" such interaction enriches spiritually the inner world of a person, gives aesthetic pleasure that is one of the ways for restoration of a person mental state. We hold that the essence of recovery mechanism is to supersede previous negative information that is felt in some form of fatigue, with positive information, that can cause positive feelings.

An important component of social work is an orientation of a client of a social assistance in area of enriched recreational environment, namely, providing favourable conditions that maximally contribute to the restoration of mental and physical capacities, and also successfully unload the psycho-emotional system in significant for the person activities. The main integral criteria of saturated recreational environment are the following:

1) Sensory stimuli: aesthetics and sensory richness of places for recreation; harmonization, structuring of the sensory environment (fine design of recreation);

2) Various types of activities: communicative activities serve as a way to organize the target audience - group work, collective discussion, decision-making, and discussion of the results; and also as a way of gaining knowledge; physical activities meet the needs in physical motions and development. They are an integral part of a healthy lifestyle and facilitate a person self-actualization;

3) Opportunities for cognitive activity of the individual: wide and free access to the necessary information is needed (consultations of 
specialists who teach special courses, etc.); diversity not only of content is required, but also in forms of presentation (lectures, seminars, instructions, discussions, etc.); saturation of communication with productive issues through skilful choice of meaningful goals;

4) Opportunities for the personal aesthetic activities should be aimed at satisfying the need for beauty (external, spiritual, relations);

5) Opportunities for bringing to fullness the creative abilities of individual should be offered in the variety of forms, content, and with orientation of cognitive activity. It is necessary to provide the possibility of making free choice of their interests and opportunities;

6) A degree of choice freedom of a person in various activities;

7) Optimal organization of activities;

8) The interaction of all participants in recreational activities.

Design and effective implementation of recreational programmes is one of the main means that creates a holistic "I-image" of the individual and his/her various components are taken into consideration. They are following: rational-cognitive (personal experience, theoretical notions); emotional-sensory (emotional response to the expression of his/her own self); sensory-perceptual (adequate perception of body signals, which are formed on the basis of "body schema" and supplemented by audible, visual and other signals); motivational (need to be a creative person, measure of responsibility, priority of psychological, mental, physical health in the individual system of values, readiness for creative activity in the system of well-being).

Transformation of "I-image" is determined by psychological, cultural, social, economic, family, educational relations. We cannot but agree with L. Vygotsky and H. Kostiuk, that the content of a person's image is influenced simultaneously by the cultural environment in which a person engages with others; the nature and content of the activity s/he does; relations that are established. In order to change the self-perception, raise the level of adequacy of the individual's self-esteem, bring into compliance pretensions of the individual with his capabilities, namely harmonize the components of "I-image", one can influence the personal orientation, the readiness of a person to behave in a certain manner, change the leading path, expand the area of the self-realization of the creativity and the world perception. 


\section{CONCLUSIONS}

Thus, we point out to the following important theoretical principles of our studies:

1) integrity, thoroughness in solving social problems are provided by holistic approach to social work taking into consideration internal and external conditions, factors, statuses in their interrelationship and mutual influence;

2) integral, all-embracing and orientated nature of social work reveals itself in bringing to fullness its creative potentials through the operation of numerous functions and particularly recreational function when personal efforts of a client are refreshed for using of his/her individual and social resources in order to influence the situation and to keep a balance between a client and living environment;

3) The theoretical foundations of adaptation and socialization in their interrelationship fulfil an important role in the theoretical justification of recreational mechanisms, means, and techniques of social work. The adaptation being a part of mechanism of socialization takes place as a total sum of adaptations to the diverse life situations when the social experience is accumulating the norms and values are mastered. Each step of the adaptation enriches the social experience and makes easier the further process of human adaptation. This is the essence of the adaptivedevelopment model of socialization that helps to open up the additional possibilities for correction of social work based goals and functions as supplementary mechanism of socialization;

4) The recreational approach itself that assists in realization of a social work is a synthesis of diverse theories and practices and it is directed to the restoration of a person (in physical, psychological, creative, cultural and spiritual aspects) who requires social assistance. The recreational approach is aimed toward carrying out of an important function of reflection; also it leads to realization of its prominent role in the processes of orientation in the surrounding reality, adaptation, and socialization as well as toward his/her real transformation;

5) Poly-functionality is the final goal of the integrative model construction as well as theoretical justification and practical fulfilment of the recreational programmes, measures, psychologically oriented actions (such as developing, formative, correcting, mobilizing, image creating and so on) on the basis of interpersonal distinctions of individuals who receive 
social assistance. Each of these recreational methods and tools comprehensively influences at any level of psycho-technology: physiological, emotional, intellectual, personal, and social spheres of personality. It supports the formation of his/her value orientations, moral, volitional, and creative sphere bringing to fullness the adaptive and creative potentials;

6) The fundamental principle of social work is a motivation of a person with awareness of what s/he is doing and willingness to use his/her own energy, abilities, moral, and volitional capacities for achieving specific purpose. Therefore we consider that the usage of this fundamental principle of social work will assist in attaining such recreational result as formed and enlarged optimistic-realistic world-view and adequate perception of the world by the subject of social work. Thus, such result is an important sign of his/her viability, worldly wisdom, and emotional resistance to adverse factors of everyday life, ability to adequately discern the real life situations and to effectively solve the issues associated with self-expression.

\section{SUMMARY}

The article theoretically analyses integral, all-embracing, and orientated nature of social work that reveals itself through the operation of numerous functions and particularly recreational function. This is possible by optimizing the personal efforts of a client in using of his/her individual and social resources in order to influence the situation and to keep a balance between a client and living environment. It focuses on explaining the possibilities to use the theoretical foundations of adaptation and socialization in their interrelationship particularly the adaptivedevelopment model of socialization. In order to justify theoretically the recreational mechanisms, means, and techniques of social work for correction of social work based goals and functions as supplementary mechanism of socialization.

This article pays attention on the recreational approach as a synthesis of diverse theories and practices, and particularly on the restoration of a person who requires social assistance in his/her different needs including an adaptation to the changing environment, and his/her real transformation and socialization. It demonstrates that poly-functionality is the final goal of constructing of the integrative models, theoretical justification, and 
practical fulfilment of the recreational programmes. The measures and psychologically oriented actions (such as developing, formative, correcting, mobilizing, image creating and so on) on the basis of interpersonal distinctions of individuals who receive social assistance refers to final goals as well.

The article mentions some recreational methods, tools that comprehensively influence physiological, emotional, intellectual, personal, and social spheres of personality; that support the formation of his/her value orientations, moral, volitional, creative sphere bringing to fullness the adaptive and creative potentials. The recreational result of the achieving the fundamental principle of social work is a formation, development of the optimistic-realistic world-view, and adequate perception of the world. Thus, such result is an important sign of his/her viability, worldly wisdom and emotional resistance to adverse factors of everyday reality, his/her ability to adequately discern the real life situations and to effectively solve the issues associated with self-expression.

\section{REFERENCES}

1. Александровский Ю.А. Состояния психической дезадаптации и их компенсация. М.: Наука, 1976. 272 с.

2. Ахмедов Т.Н., Жидко М.Е. Психотерапия в особых состояниях сознания: История, теория, практика. Харьков: Фолио, М.: ACT, 2000. $768 \mathrm{c}$.

3. Большаков В.Ю. Психотренинг. Социодинамика, упражнения, игры. СПб: Социально-психологический центр, 1996. 380 с.

4. Бурлачук Л.Ф., Кочарян А.С., Жидко М.Е. Психотерапия. Спб.: Питер, 2003. 480 с.

5. Вачков И.В. Основы группового тренинга. Психотехники. М.: Ось-89, 2001. 224 с.

6. Кант И. Соч. в 6 томах. Т.6. М.,1966. 365 с.

7. Кірсанов В.В. Основні напрями дослідження рекреації. Вісник книжкової палати. 2004. № 10. С. 19-23.

8. Коваль Л.Г., Звєрева І.Д., Хлєбік С.Р. Соціальна педагогіка. Сочіальна робота. К.: ІЗМН, 1997. 392 с.

9. Корекційна робота психолога / упоряд. О. Главник. К.: К 66 Шкільний світ, 2002. 112 с. 
10. Костюченко О.В. Основні напрями психологічного дослідження адаптації та рекреації у контексті психічного здоров'я. Актуальні проблеми психології. Т. 12. Вип. 10. Житомир: Вид-во ЖДУ ім. I Франка, 2010. С. 154-161.

11. Костюченко О.В. Художня перцепція в системі рекреації. Актуальні проблеми психології. К: Фенікс, 2015. Т. ХІІ. Психологія творчості. Вип. 21. С. 174-184.

12. Латинсько-український словник: 10 тисяч найуживаніших латинських слів 3 максимальним відтворенням їхніх значень українською мовою. К. : Українські пропілеї, 1998. С. 548.

13. Ломов Б.Ф. Методологические и теоретические проблемы психологии. М.: Наука, 1984. 444 с.

14. Лукашевич М.П., Мигович I.I. Теорія і методи соціальної роботи. 2-е вид., доп. і випр. К.: МАУП, 2003. 168 с.

15. Моляко В.А. Проблемы психологии творчества и разработка похода к изучению одаренности. Вопросы психологии. 1994. № 5. С. 86-95.

16. Моляко В.О. Психологічна теорія творчості. Наукові записки Інституту психології ім. Г.С. Костюка АПН України. К., Нора-Прінт, 2002. Вип. 22. 350 c.

17. Мясищев В.Н. Психотерапевтическая энциклопедия / Под. ред. Б.Д. Карвасарского. Изд. 2-е, доп. и перераб. СПб.: Питер, 2000. С. 394-195.

18. Никифоров Г.С. Психология здоровья. СПб: Речь, 2002. 256 с.

19. Новиков А.М. Методология художественной деятельности. М.: Єговес, 2008. 72 c.

20. Психологический словарь / [под ред. В.П. Зинченко, Б.Г. Мещерякова). 2-е изд. М.: Астрель, 2004. С. 768.

21. Психологічне забезпечення психічного і фізичного здоров'я / За заг. ред. М.С. Корольчука. К.: ШКОС, 2002. 296 с.

22. Рекреаційні аспекти активних творчих методів сенсорноперцептивної активації для дітей підліткового та юнацького віку. Проблеми сучасної психології. Вип.19. Кам'янець-Подільський: Аксіома, 2013. С. 313-323.

23. Розов В.І. Адаптивні антистресові психотехнології. К.: Кондор, 2005. 278 c. 
24. Рудестам К. Групповая психотерапия. Психокорекционные группы: теория и практика. М.: Прогресс, 1990. 368 с.

25. Сандомирский М.Е. Защита от стресса. Физиологическиориентированный подход к решению психологических проблем (Метод РЕТРИ). М: Из-во Института Психотерапии, 2001. 336 с.

26. Социальная работа / под ред. В.И. Курбатова. 2-е изд. Рн/Д.: Феникс, 2003. Ст. 7.

27. Технологии социально-психологических тренингов. М.: Редакционно-издательский центр Консорциума «Социальное здоровье России», 2001. 208 с.

28. Ялом И. Теория и практика групповой психотерапии. СПб: Питер, 2000. 640 c.

\section{Information about author:} Kostyuchenko O. V. Assistant Professor at the Department of Psychology of the Kyiv National University of Culture and Arts 


\section{THE CHILD NEGLECT AS A SOCIO-PSYCHOLOGICAL PROBLEM}

\section{Mitina S. V.}

\section{INTRODUCTION}

The problem of the child neglect, which arose at the end XX century in our society, remains relevant for Ukraine at the present time. This is primarily due to the political and economic crisis in which Ukrainian society is located, military actions in the east of the country, destabilization of social life, internal migration, which led to an increase in the number of families who are in difficult life situations and cannot provide support for their children. These factors lead to the proliferation of child neglect and the to increase the number of minors with deviant behavior.

It should be noted that the problem of child neglect is interdisciplinary and studied by different specialists. In the scientific literature reveals a legal (V.O. Bolotova, I.V. Gorobets, N. Guivan, M.M. Gurenko, L. Kryvachuk, L.L. Tikhonenko) and socio-pedagogical aspects (G.M. BevZ, L.S. Volinets, I. Zvereva, A.Y. Kapska, N.M. Komarova G.M. Laktionova, V.M. Orzhehovska, etc.) problems of child neglect. In psychology, the relationship between the phenomenon of neglect and deviant behavior, its influence on the deformation of the personality and interpersonal relations is revealed (N.Yu. Maksimova, S.V. Mitina, I.V. Pesha, R.M. Tkach, Yu.M. Udovenko, T.A. Yurchenko etc.). However, there are not enough works devoted to the socio-psychological aspect of the study of the phenomenon of neglect of children and teenagers, a systematic analysis of the social and psychological prerequisites of the occurrence of this phenomenon. Meanwhile, taking into account socio-psychological factors would allow to apply a differentiated approach to providing psychological assistance to them and to determine the optimal forms of their livelihood in the process of re-socialization of neglected teenagers.

\section{Analysis of the concept and structure of child's neglect}

Regarding the category of neglect children, different terms are used in the literature: «homeless», «street children». According to the UNICEF 
definition, "street children are minors for whom the street has become a permanent place of stay". In a narrow sense, the notion "street children» is synonymous with the notion "homeless children" - "these are children and teenagers under the age of 17 , for whom the street is the main social environment and who are deprived of their permanent residence. From other children, who are most of the time on the street they are distinguished by the need to find a means of livelihood, so they actually lose the status of children, and become members of informal street gangs, along with marginalized"1.

In Ukraine, the concept of «street children» unites two other concepts: "homeless children" and "neglect children". In accordance with the Law of Ukraine "On the Protection of Childhood", homeless are children who were abandoned by their parents, left their own families or children's institutions where they were brought up, and do not have a specific place of residence ${ }^{2}$.

Accordingly, of the child neglect is the weakening or lack of supervision of the child by the parents. Consequently, the concept of «child neglect» is a broader concept than «street children»-a child who is deprived of parental care but lives at home. The first indicator of the neglect of children is the lack of care, positive influence on the part of parents, insufficient control over the behavior and activities of children. The extreme manifestation of neglect - "homelessness", is legally defined as the special social condition of a minor, which is characterized by:

a) lack of domicile (homelessness);

b) rupture of relations with parents (persons who replace them);

c) alienation from all institutions of socialization (family, educational and other institutions);

d) the lack of socially useful work.

V.M. Orzhehovska, notes that homelessness «like a long illness, goes through several stages of its development.» The initial phase of this social disease is neglect, and the final stage, which is on the verge of irreversibility, is homelessness, which determines the position of the minor himself, his peculiar social status, which he accepts on his own will or due

\footnotetext{
${ }^{1}$ Реалізація конвенції ООН права дитини в Україні: досягнення, проблеми, перспективи (за період 2009-2016 р.р.). Державна доповідь про становище дітей в Украӥні. Київ: Міністерство соціальної політики України, 2016. С. 24.

2 Про забезпечення організаційно-правових умов соціального захисту дітей-сиріт та дітей, позбавлених батьківського піклування. Закон України (зі змінами від 08.02.2018 року) Відомості Верховної Ради України. 2005. № 6. С. 147.
} 
to some circumstances. At the same time, neglect can be either the end stage of the social process, that is, the result of the transition from the "normal" state to the neglected state, or intermediate, that is, one of the stages of personality de-socialization and the transition to the state of homelessness, which is characterized by a complete separation of the minor from the family and is connected loss of permanent residence and occupation $^{3}$.

In our opinion, it is necessary to distinguish between children with partial and complete neglect. Children with partial neglect are children from families in which parents spend all day at work, which is why the child is deprived of adult control and stays at home after school. Partial neglect does not always lead to negative consequences: if children can take care of themselves after school, and most importantly, they maintain an emotional connection with their parents. Complete neglect regarding children is observed in all antisocial families. The lack of social assistance and psychological support for the child with the loss of parents, also often leads him to neglected status and further homeless ${ }^{4}$.

The concept of "neglect" is interpreted primarily from the position of a sociological approach as a social phenomenon; at the same time attention is focused on the social environment, the social conditions in which the child is. N. Komarova identifies nine groups of neglected children based on the degree of family distress and the child's time on the street from extremely negative, when children have no family and live permanently on the street, up to the group of children who live at home, have a family, but spend most on the street ${ }^{5}$.

F. Mustaeva takes as a criterion for classification the motivation of leaving a teenager from home. External motivation occurs when a teenager runs away from home due to the social disadvantage of the family. Internal motivation to leave home is observed in adolescents, who, due to their psychological characteristics, are prone to vagrancy and other types of deviant behavior ${ }^{6}$.

\footnotetext{
${ }^{3}$ Оржеховська В.М. Дитяча бездоглядність та безпритульність: історія, проблеми, пошуки: навч. посібник. Київ: Логос, 2004. 172 с.

Мітіна С.В. Соціальні чинники бездоглядності підлітків. Вісник Київського національного університету імені Тараса Шевченка Київ, 2013. № 1(7). С. 74-77.

Главник О., Комарова Н. Діти вулиці: хто вони і як їм допомогти. Київ: Главник, 2006. 112 с.

6 Мустаева Ф.А. Основы профилактики безнадзорности и беспризорности несовершеннолетних. Москва, 2003. 456 с.
} 
Summarizing the positions of different authors, as well as the results of our research, the following varieties of neglected teenagers can be identified:

- teenagers who lost their parents and, due to the lack of surgical intervention of the guardianship bodies, were recently found on the street;

- teenagers-runaway from boarding schools;

- teenagers who have a family, but due to family problems spend most of the day on the street;

- teenagers, who are permanent residents in the street as a result of a conscious rejection of the situation of family trouble;

- teenagers from socially well-off families who run away from home as a result of a conflict with their parents;

- teenagers with patoharakterologichnimi features that leads to uncontrolled behavior.

Consequently, in the category of neglected teenagers can get both from disadvantaged, and external well-off families, as well as children who do not have a family. The neglected can be one of the stages of personality desocialization and the transition to the state of homelessness, which is characterized by complete separation of the minor from the family and is connected to the loss of permanent residence

\section{Factors of the child's neglect}

The analysis of the literature on this problem allows us to identify two groups of factors for the increase in the number of neglect children at the present stage of development of society. These are the factors associated with the macrosocium: political, socio-economic, social and legal, and the causes caused by the microsocium: socio-pedagogical, sociopsychological, medical-psychological.

The global political factors of increasing the number of neglect children is the dramatic change in the functioning of the political system of Ukraine. The system of values has changed, the moral and ethical guidelines that existed in Soviet times are neglected by society, but others are still inefficient. A society of anomia described by E. Durkheim arose in the society, which gives rise to different types of deviant behavior, and in particular leads to an increase in child neglect. In addition, in today's difficult political conditions, the number of neglect and homeless children 
has increased significantly, due to the problem of relocating a significant number of families with children from Donetsk and Lugansk regions.

Socioeconomic factors include factors that for a long time violate life and deform the lives of people. Military operations in the east of the country led to a noticeable increase in the number of families who found themselves in a difficult life situation. According to sociological studies, about $70 \%$ of families self-identify their level of material status "below average"; the number of families who solve their material problems through the use of child labor has increased. The low level of social and legal protection of the institution of family and children leads to the economic exploitation by adults of child labor, weakening the responsibility of parents for the maintenance and upbringing of children. There is no sufficiently clear legal mechanism for the prevention of child neglect ${ }^{7}$.

Socio-psychological factors are connected with the moral and psychological crisis of society; with the crisis of the family institution, an increase in the number of divorces, single-parent families, aggravation of family conflicts, violence against children. The inability of parents to adapt to the realities of life, material distress leads to a deterioration in the psychological climate of the family, manifestations of deviant behavior of adults. One of the main reasons for the neglect of children is the alcoholism of parents. Due to the anti-social way of life, failure to parental responsibilities for the maintenance and education of children are deprived of parental rights, thereby increasing the number of children of social orphans. It should be noted that of more than 70 thousand orphans, less than 30\% are biological orphans. The rest are children who became orphans with living parents, thus the problem of child neglect is inextricably linked with the problem of social orphanhood ${ }^{8}$.

The socio-pedagogical factors for the increase in the number of street children is the crisis of the institute of education, the decline in the level of employment among children and teenagers after school hours. Out-ofschool activities during after-hours are curtailed, the number of different types of studios and clubs in schools and out-of-school institutions has

\footnotetext{
7 Горобець I. В. Механізми державного управління у сфері протидії дитячій безпритульності та бездоглядності в Україні: автореф. дис. на здобуття наук. ступеня канд. держ. упр.: 25.00.02 “Механізми державного управління”. Івано-Франківськ, 2012. С. 13.

8 Захист дітей, які потребують особливої уваги суспільства [Електронний ресурс] : статистичний збірник за 2017 рік / Державна служба статистики України ; [відп. за вип. О. О. Кармазіна]. Київ: ДССУ, $2018.77 \mathrm{c}$.
} 
sharply decreased. All of these factors affect the marginalization of teenagers and increase the likelihood of their going out.

Medical and psychological factors are associated with an increase in the number of children with psychosomatic and neurotic anomalies, character accentuation, and the presence of genetic predisposition. The spread of alcoholism and drug addiction among adults leads to an increase in genetically determined mental illness of children.

One of the main causes of child neglect at the present stage is of family troubles. A. Kapska notes the causes of socio-economic and moral and psychological, which lead to a deterioration of the child's position in the family and deprivation of parental care and guardianship. Socioeconomic factors is unemployment, the lack of permanent housing and places of work, or leaving their parents on incomes for abroad, with the result that children are neglected for a long time ${ }^{9}$. According to statistics in Ukraine in 2018 year, out of the number of economically active persons, $9.1 \%$ of women and $10.1 \%$ of men remained without work. In the case of long-term unemployment, the stressful state of the parents can turn into depression, lead to a loss of interest in life and marginalization.

Foreign scientists suggest the relationship between poverty, the social situation of parents and the child's propensity for deviant behavior. E. Durkheim noted that poverty is one of the main reasons, which predetermines the neglect of children. According to K. Bartol, upbringing deficiencies most often affect teenagers from families with low material income and the offenses of these children are the result of the negative experience they receive in the family ${ }^{10}$.

However, in the opinion, T.A. Yurchenko's financial distress of the family is an important, but not the decisive factor in the departure of children from the family. This requires a combination of interrelated factors: poverty, parental unemployment, family conflict, low educational level, parental asociality, and other reasons ${ }^{11}$.

A. Kapska notes that besides socio-economic reasons, there are still morally psychological factors that lead to the breakup of families, although they are also a consequence of the socio-economic and spiritual crisis. There are two types of family deformation: structural, associated with a violation of

\footnotetext{
${ }^{9}$ Капська А.Й. Організація і технології соціальної роботи з дітьми вулиці. Київ: Інтернаціональний Союз. Ліга соціальних працівників України, 2004. 260 с.

${ }^{10}$ Бартол К. Психология криминального поведения. СПб.: прайм-ЕВРОЗНАК, 2004. 352 с.

11 Юрченко Т.А. Соціально-психологічний підхід до проблеми бродяжництва дітей. Aктуальні проблеми практичної психологї: зб. наук. праџь. Херсон, 2006. С. 280-281.
} 
the structural integrity of the family and psychological - a violation of the system of interpersonal relationships, which leads to the development of an unfavorable psychological climate in the family. Psychological and structural deformations of the family lead to disharmonization of family relations and a negative atmosphere in the family. According to statistics, the 01.02.2018 year in Ukraine, more than 128 thousand incomplete and 333.187 large families who need social support ${ }^{12}$.

Divorce of parents is one of the most notable trends of family trouble at the moment. In single-parent families, mothers are forced to work fulltime in order to support the family, so the neglect of children in such families is higher than in full families, as well as the deviant behavior of children's behavior. Secondary families also often have a crisis, especially in the relationship between step-parents and foster children. Unhealthy emotional atmosphere in the family, conflict adversely affects the psyche of children, their social adaptation, leads to the child ignoring family values and alienating him from the family.

Research by I. Pesha shows that $46 \%$ of parents deprived of parental rights are chronic alcoholics, 34\% lead an immoral lifestyle, 17\% have committed crimes and are in places of detention. An asocial lifestyle of parents, different types of addiction, lead to moral degradation of parents. There are cases when the parents themselves force their children into begging or selling them criminal groups to participate in criminal activity. Having mastered the negative behavioral stereotypes, the teenager himself embarks on the path of crime and immorality ${ }^{13}$.

The abuse of alcohol by parents or other psychotropic substances often leads to various forms of violence against the child: physical, psychological or sexual. The study of R.M. Tkach testifies that ignoring children by their parents, a cruel attitude, form feelings of alienation and cause children to leave the family. Minors who are not satisfied with their life and family conditions are trying to change them. Going out on the street becomes a way to solve a specific problem, which is further consolidated into the strategy of adolescent behavior ${ }^{14}$.

\footnotetext{
12 Захист дітей, які потребують особливої уваги суспільства [Електронний ресурс]: статистичний збірник за 2017 рік. Державна служба статистики Украӥни; [відп. за вип. О.О. Кармазіна]. Київ: ДССУ, $2018.77 \mathrm{c}$.

${ }^{13}$ П'єша I. В. Соціальна допомога безпритульним та бездоглядним дітям, що надається закладами та організаціями різного підпорядкування. Украӥнський соиіум. 2007. № 5-6 (22-23). С. 49.

${ }_{14}$ Ткач Р.М. Соціально-психологічні чинники, що зумовлюють схильність дітей до бродяжництва. Актуальні проблеми психології: зб. наук. працьь Ін-ту психології ім. Г.С. Костюка АПН України. Київ, 2006. T. VIII ,ч. 8. С. 298-303.
} 
Among the neglected there are children who are brought up in seemingly prosperous families with a material condition. Most often, these are families with defects in upbringing, among which typical are families with authoritarian, custodial, condescending and chaotic upbringing styles. In an authoritarian family, too high demands are made on the child. Constant tension leads to the desire to get rid of this unpleasant state and can induce a teenager to go out. In a family with a custodial parenting style, a child is surrounded by excessive attention, but having experienced difficulties and not having the necessary skills to overcome them, such a child often falls under the influence of negative factors. An indulgent upbringing style is manifested in insufficient attention to the child by the parents, the child actually does not know the prohibition and restrictions on their part, perceiving this as a manifestation of indifference and emotional rejection. Subsequently, these children are not able to take into account the interests of other people, to establish strong emotional connections, they are not ready for restrictions and responsibilities. With chaotic styles there is no unified approach to education, there are no clearly defined requirements for the child, which deprives him of a sense of stability and also provokes social disadaptation ${ }^{15}$.

Thus, family dysfunction is a major factor in neglect of childrent, the separation of children from the family and their exit into the streets occurs primarily in socially disadvantaged and crisis families: incomplete, secondary or families with the wrong type of education.

\section{The impact of neglect on the process of socialization of teenagers}

Neglect is a crisis of childhood and is manifested in the social disadaptation of teenagers, varieties of deviant behavior: alcoholism, drug addiction, substance abuse, aggression, vagrancy, asocial lifestyle.

O. Selivanova considering neglect as a process of disadaptation distinguishes two phases:

1 - internal - the alienation of the individual from the institutional society;

2 - adaptation to an extra-institutional environment forms an external tendency in behavior that leads to a passive lowering to the "social bottom" and complicates the process of re-socialization.

\footnotetext{
15 Максимова Н.Ю. Психологія соціальної роботи із проблемними сім'ями: навч. посіб. Київ: ВПЦ “Київський університет”, 2017. 463 с.
} 
O. Selivanova notes that going out on the street can be like a meaningful behavioral act, especially if a neglected teenager is not actively willing to resist socialization and consciously demonstrates models of deviant behavior. In this case, neglect can be viewed as a model of behavior chosen by a teenager as a result of a conscious rejection of a situation that does not suit him in a family or in a social institution.

The reasons for leaving the teenager from outwardly prosperous family are ambivalent: on the one hand, the failure of actions expected from family members in terms of establishing a relationship with a teenager, and on the other - the inefficiency of its own activities on the adaptation to the institutional environment. These two trends may lead to the formation of internality relative to an extra-institutional environment. In this case, the behavioral potential of exit from the microsocium, which does not suit the teenager, is higher than the potential of unsuccessful attempts to adapt to this microsocium. The result of an attempt by a teenager to preserve the values of society can become a reticence, a withdrawal into the world of one's own fantasies, the emergence of neuroses, complexes and other disruptive reactions. In the case of seeking to challenge the values of society, it is possible to demonstrate an teenager antisocial behavior, which leads to more of its rejection by society, but it no longer has any meaning for him. It is the new personal experience that is valuable for him in this situation, whatever the moral and ethical coloring of this experience.

The behavior of a teenager in the process of adaptation to the street depends on what his previous development was, as well as on the quality of the tumors of previous secular periods. Adaptation to the "street" is always inconclusive, since the factors to be adjusted are constantly changing, the teenager's tension is increasing, the adaptation mechanisms are overstrained, the satisfaction of even basic needs is immediate and unwarranted. Thus, being on the street on their own initiative, the adolescent is faced with the problem of adapting to a low-structured, unstable extra-institutional environment.

The result of unsuccessful attempts at adaptation, as noted by O. Selivanova, is the emergence and development of "crises":

1) the crisis of indifference of the installation, when there is no longer attachment to the object (the institutions of society and their representatives); 
2) the crisis of unstructured world;

3) the crisis of emptiness that occurs when the social situation and leading activities change, experiencing the unpredictability, uncertainty of the future;

4) the crisis of promiselessness that arises when the connections of specific events with plans and real channels for their implementation are poorly represented in the mind ${ }^{16}$.

This is precisely the disadaptation of a neglected teenager as a state of internal dissonance, which is in a potential conflict between the attitudes of "Ego" (the desire to "prove to everyone the rightness") and direct experience (inability to carry out what was intended), which does not allow the teenager to restore integrity. Externality of behavior is characteristic of this state.

Going out on the street should be viewed not only as a distance from the family, but as a transfer of the teenager to the specific environment of vagrancy of minors, where there are customs, habits, norms and patterns of behavior. The teenager changes the subjects of identification, his moral and legal consciousness also changes. As a result of the influence of a negative microenvironment in a teenager, there is a destruction of positive values, instead of which antisocial norms and forms of behavior are assimilated. Thereby, neglected children sever any connection with society, fall as if in a social vacuum, remain outside society.

The dominant motive in the search for isolation is the need for understanding and affection. It is precisely the similarity of difficult characters that is the main reason for the unification of neglected teenagers. Communication with deviant peers correlates with the deficiency of social skills. The neglected teenager receives social recognition and selfaffirmation in the group of "similar", in such a group he feels "its", at the same time, all the troubles of life (hunger, cold, lack of hygiene, fear) begin to acquire attractive power, since the teenager believes that having defended his right to live outside of society, he established his potential for independent living in the street.

The reaction to the situation of chronic family distress, psychological violence, children form negativity or passive refusal to everything that is imposed on them as a habit to imitate any activity, at the same time, the

16 Селиванова О.А. Личностно значимые условия реинтеграции “уличного” подростка. Москва: Генезис, 2004. 239 с. 
ability for systematic efforts, which is important for independent living, is not formed. The teenagers becomes accustomed to the fact that little depends on him, resulting in an inability to plan his life, a low understanding of his ability to cope with problems and life difficulties.

The lack of positive communication with parents predetermines the development of inadequate communication with others, when protective situations of behavior dominate in conflict situations: inability to constructively solve a problem situation, outbreaks of aggression, and desire to shift responsibility to others. Disadaptation of the neglected children is manifested in the loss of social orientation of feelings, distrust of the social environment, social non-contact, inability to share their social roles, to establish friendly relations.

The study of N. Maksimova showed that the internal contradiction between the intensification of the teenager's negative emotions associated with the fact of domestic violence and the inability to express them in communication leads to a kind of "freezing" of emotions. At the same time, the development of the emotional sphere is inhibited, the formation of empathy does not occur, a peculiar emotional dullness is formed. This leads to the fact that in future adult life, such a person is not only unable to express his feelings, but also shy of them, trying to avoid situations related to the emotional area of life ${ }^{17}$.

Neglect negatively affect the homeostasis in the system of childsociety on the level of behavioral manifestations. The state of constant threat forms a catastrophic cognitive model of the world and the need for barriers when interacting in the form of aggressive reactions, avoidance of contact and violation of social norms. Studies show that children tend to vagrancy, have a specific formula of life style, based on distrust and caution in relation to people, which manifests itself in aggressive and hostile behavior.

Thus, the research of scientists shows that the consequence of the neglect of children is a violation of the process of their socialization, which is manifested in: - social disadaptation of minors; adaptation to the extrainstitutional environment, the inclusion of groups of asocial character and various types of deviant behavior.. Social factors, create the primary prerequisites for personal development of neglected teenagers. The lack of

\footnotetext{
${ }^{17}$ Максимова Н.Ю. Психологія соціальної роботи із проблемними сім'ями : навч. посіб. Київ: ВПЦ “Київський університет”, 2017. 463 с.
} 
positive emotional relationships with loved ones, the child's insecurity in the constancy and reliability of parents' love, their continued support and full acceptance is manifested in distortions of personal development, which in turn is an obstacle to the re-socialization of neglected teenagers.

\section{Psychological aspects of the re-socialization of neglected teenagers}

The problem of child neglect is typical of many countries, regardless of their level of wealth. Each country determines its own ways of overcoming this problem and providing social and psychological assistance to families who are in a difficult life situation. In western countries (Austria, Great Britain, Holland, Germany, USA, etc.), social services for working with children are developed. Support services for children and families provide patronage services, family psychotherapy, educational activities. Psychological correction centers provide assistance to families who have problems in dealing with children, advise them on psychological and pedagogical issues ${ }^{18}$.

Social Security abroad focuses on a normal stay of the child in the family, the identification of children who are abused by their parents. Social and legal protection of the child is provided taking into account the conditions of the social environment, and also provides for the provision of support to parents ${ }^{19}$.

In many Western countries (Austria, Germany, the US), there are multidisciplinary centers that provide psychotherapy to the children, the teenagers and their parents. Such centers act as "linear" structures of social services. For example:

- centers that specialize in helping to the teenagers who have difficulty communicating with their parents;

- centers that focus only on family support;

- centers that provide assistance to teenagers who are prone to alcohol and drugs.

"Linear" structures communicate with legal services, health organizations, social welfare services. Family support centers provide preventive activities and assist in critical conditions.

\footnotetext{
${ }^{18}$ Berg T., Vink C. Child and Youth Social Care Systems Abroad Lessons on strategies and systems from England, Germany, Norway and Sweden. The Netherlands Youth Institute 2009. P. 64.

${ }_{19}$ Кубіцький С. Історія соціальної роботи в зарубіжних країнах: навч. посібник. Київ: ДАКККІМ, 2009. $298 \mathrm{c}$.
} 
In Austria, children who have been subjected to violence in the family can be admitted to the temporary residence group at the regional crisis center. At the center, children continue to attend a regular school, and maintain relationships with their friends and parents, with whom work is also underway. The task of the Crisis Center - help the family overcome difficult circumstances ${ }^{20}$.

In Germany, widespread therapeutic and prophylactic Day care facilities for children. These are semi-stationary organizations in which children are from 8 to 17 hours. These centers make it possible to eliminate the lack of development in the child and correct behavior disorders, as well as conduct family psychotherapy.

For teenagers from the age of 16 who have left the family and have independent life experience, social dormitories are functioning in the United States. In these institutions, the principle - "adult" independent life of teenagers led by social workers. When a teenager is ready to leave the institution, they find separate housing for him to begin independent adulthood. But despite the fact that the teenager leaves the institution, social services helps him in solving life problems ${ }^{21}$.

Juvenile offenders, by court decision, are sent to closed rehabilitation centers. An example of a closed correctional institution is a Juvenile Center Hammargarden in Sweden, where at the same time contains no more than 24 teenagers and a staff of 76 persons (police officers, social workers, psychologists, psychotherapists, educators, doctors). The center represents a complex of houses in a suburban area: administrative house, school, kitchen, workshops, and five two-storeyed houses in which teenagers live. The barrier, as well as security, are absent on the territory of the center, however, walks, visits to schools, workshops, teenagers take place necessarily accompanied by an educator. School programs of the center are adapted to the level of knowledge and individual characteristics of the development of each teenager. Classes are held in groups of 3 teenagers and individually. In these institutions, teens are kept for up to 8 weeks. The task of the social service is to bring the teenager back to normal and return to the family ${ }^{22}$.

\footnotetext{
${ }^{20}$ Domestic Violence Perpetrator Programs in Europe, Part I: A survey of Current Practice. International Journal of Offender Therapy and Comparative Criminology. 2012. № 10. P. 56.

${ }^{21}$ Ковчина I.M., Вивчення досвіду соціально-правового захисту дітей та молоді у США та Канаді. Науковий часопис НПУ імені М.П. Драгоманова Серія 11. Соціологія. Соціальна робота. Київ 2007. C. $63-73$.

${ }^{22}$ Berg T., Vink C. Child and Youth Social Care Systems Abroad Lessons on strategies and systems from England, Germany, Norway and Sweden. The Netherlands Youth Institute. 2009. P. 33-41.
} 
The separation of the child from the family is used only in extreme cases, when the work of social services does not have a positive result, the child is removed from the family and transferred to a foster family. The leading trend in the social policy of the countries of Western Europe and America is the deinstitutionalization of the upbringing of children deprived of parental care. Boarding schools have almost ceased to exist, and in those that remained children who, for medical reasons, cannot live in foster care. In Austria, a well-developed system of adoption and foster the activities of institutions. Particular attention should be paid to the functioning of foster families in the In Great Britain and the activities of social services in relation to their support ${ }^{23}$.

The growing number of the neglected children in Ukraine at the end of the twentieth century, led to the need for reforms in the field of childhood policies and the implementation of urgent social and legal measures. Specialty institutions for children and adolescents have been established. Since 1997, a network of shelters for minors has been operating, the purpose of which is to provide social protection for children, their temporary placement (up to three months), status determination, and subsequent living arrangements. Since 2001, the reorganization of shelters in the centers of socio-psychological rehabilitation. At such a Center, neglected children can stay up to 9 months around the clock and another 12 months - in the day hospital. According to statistics from the Ministry of Social Policy on 1 January, 2018, in Ukraine there were 8 shelters and 75 centers for social and psychological rehabilitation for minors, which provide the first "emergency" assistance to the children ${ }^{24}$. Social rehabilitation centers solve the following tasks:

- preventive work on the prevention of neglect;

- provision of free social services to minors at social risk;

- identifying the causes of social maladjustment of minors;

- development of individual programs for the social rehabilitation of the children and the teenagers;

- provision of temporary stay of the neglected children and the teenagers;

- provide psychological assistance to child neglect;

\footnotetext{
23 Лактионова Г.М. Инновационные формы опеки детей: международный и национальный опыт. Київ: Науковий світ, 2011. $161 \mathrm{c.}$

24 Захист дітей, які потребують особливої уваги суспільства [Електронний ресурс] : статистичний збірник за 2017 рік. Державна служба статистики України; [відп. за вип. О.О. Кармазіна]. Київ: ДССУ, 2018. $77 \mathrm{c}$.
} 
- the solution of the question of the subsequent living arrangement of minors. Thus, the Social and Rehabilitation Centers make it possible to comprehensively solve the problems of correction and rehabilitation, which is aimed both at the child himself and at the society in which he or she is located ${ }^{25}$.

Crisis centers for social and psychological assistance for families began to function: - patronage of families at risk, - social support for families in the process of rehabilitating children with experience of deviant behavior.

The organization of preventive and remedial work of the center with the family is based on the following principles:

- the principle of timeliness provides for early detection of family distress, which helps to avoid extreme measures - depriving parents of parental rights;

- the principle of an individual approach in the choice of means of prevention and correction with each family;

- the principle of encouraging the family to self-help provides for the revitalization of its own internal resources for lifestyle changes ${ }^{26}$.

$\mathrm{N}$. Maximova notes that the re-socialization of the neglected children and teenagers provides for social, educational and psychological correction of deviant behavior. The condition for the socio-psychological assistance to the neglected children and teenagers is social control, which includes the efforts of the nearest social environment. At the same time, effective implementation of social control and the use of relevant effects is possible when analyzing not only the actions of a teenager, but also his attitude to his behavior ${ }^{27}$.

V. Orzhehovskaya suggests the following stages of the resocialization of the neglected children and teenagers:

- preparatory - removing children from the adverse conditions of the social environment, solving social and legal issues;

- organizational - conducting psychodiagnostics, development and implementation of psychotherapy programs, psychological and pedagogical correction, substantiation of an adequate educational program;

\footnotetext{
25 Система державних органів соціального захисту прав дітей-сиріт та дітей, позбавлених, батьківського піклування. Держава і право. [упоряд. О.М. Ноздріна]. Київ: Ін-т держави і права НАН України, 2006. Вип. 33. 270 с.

${ }^{26}$ Капська А.Й. Організація і технології соціальної роботи з дітьми вулиці. Київ: Інтернаціональний Союз. Ліга соціальних працівників України, 2004. 260 с.

${ }^{27}$ Максимова Н.Ю. Психологія соціальної роботи із проблемними сім'ями: навч. посіб. Київ: ВПЦ “Київський університет”, 2017. 463 с.
} 
- practical - creating and compensating for the child's social ties and conducting social and psychological monitoring of the child's condition $^{28}$.

The model proposed by Yu.M. Udovenko for the socio-psychological rehabilitation of children includes a network of Centers in which, taking into account the age of the child and the time he is on the street, work is being carried out in the following areas:

- social and psychological-pedagogical diagnostics;

- medical examination;

- preventive direction of social work;

- placement of children in the family;

- socio-psychological rehabilitation of the neglected children and teenagers.

The indicated directions of social and psychological assistance to the neglected children provide for the implementation of a differentiated approach based on taking into account the unfavorable experience of children and the violation of the main spheres of mental development. Work is being done not only with children, but also with parents, which makes it possible for the child to return to the family ${ }^{29}$.

A.. Kapska, N. Komarova offers four types of assistance Centers for the neglected children and teenagers, based on the degree of "immersion" of the child in street life and the level of disadvantage of his family:

1) Centers for the prevention of possible exit to the street children work with children who have problems, but they are still living at home;

2) Centers aimed at returning from the street children who have limited experience of street life, that is, they live both at home and on the street;

3) Centers aimed at creating social, psychological and pedagogical conditions for the return from the street of children who have sufficient experience of street life;

4) Day care centers for children who are limited in parental care ${ }^{30}$.

To ensure the temporary residence of the teenagers aged 15 to 23 years, social communities began to function in Ukraine. The goal of

\footnotetext{
28 Оржеховська В.М. Дитяча бездоглядність та безпритульність: історія, проблеми, пошуки: навч. посібник. Київ: Логос, 2004. 172 с.

29 Удовенко Ю.М. Система служб соціально-психологічної підтрімки дітей- жертв насильства (вітчизняний та зарубіжний досвід). Актуальні проблеми психології: зб. наук. праць Ін-ту психологї ім. Г. С. Костюка АПН Украӥни. Київ, 2006. Т. VIII, вип. 2. С. 336-342.

${ }^{30}$ Главник О., Комарова Н. Діти вулиці: хто вони і як їм допомогти. Київ: Главник, 2006. 112 с.
} 
social hostels is to create conditions for the social adaptation of the neglected teenagers, an external-individual form of education, assistance in obtaining a specialty and employment, preparation for independent living. The teenager can live there for three years, until he gets a profession. It will also give him the right to take up social housing registration and get social housing.

It should be noted that for the time of independence of Ukraine, a gradual transformation of the state system of custody of the children left without parents is carried out, family forms of education are being introduced.

Since of the 2008 year, the reform of the existing boarding schools began. The process of disaggregation of boarding schools continues, for example, the capacity of boarding schools has decreased from 200 pupils in the 2008 year to less than 50 children in the 2018 year. The initiated reforming processes provide of the children living conditions close to the family ones.

Over recent years there has been a tendency to adopt, 2925 of the children were adoptions in the 2017 year. However, there is no targeted psychological preparation of the children and families for adoption, therefore, there are cases of cancellation of adoption, for example, in the 2017 year there were 20 such cases ${ }^{31}$.

The most common form of placement of orphaned children is now in Ukraine is guardianship. At the beginning of the 2018 year, $72.8 \%$ of the total number of orphans and children deprived of parental care were in guardianship. It should be noted that the guardians are mostly elderly relatives. Therefore, it is necessary to develop and introduce mechanisms of social support, especially for families where the teenagers are brought up, in order to prevent them from going outside.

G. Bevz, I. Pesha note that of the foster family and the creation of the family-type orphanages is currently a form of addressing the problem of the neglect. The purpose of the foster family is the temporary custody of the children until their own parents are able to take care of them if it is impossible for the child to remain in the foster family ${ }^{32}$.

\footnotetext{
31 Захист дітей, які потребують особливої уваги суспільства [Електронний ресурс]: статистичний збірник за 2017 рік. Державна служба статистики України: [відп. за вип. О.О. Кармазіна]. Київ : ДССУ, $2018.77 \mathrm{c}$.

32 Пєша І.В Особливості функціонування дитячих будинків сімейного типу як сімейної форми опіки над дітьми-сиротами: Збірник наукових праць Херсонського державного пед. ун-ту. Херсон, 2006. Вип.13. С. 189.
} 
It should be noted that the number of children who are placed in foster families and family-type orphanages tends to increase. If in the 2009 year, 400 family-type orphanages functioned in Ukraine, by the end of the 2017 year it was 1019. The total number of children raised in foster homes and family-type orphanages at the beginning of 2018 was 12178 , which is $17 \%$ of the total number of orphans and children deprived of parental care.

However, at the stage of creation and functioning of the family-type orphanages and of the foster families there are many legal, material and psychological problems. According to G. Bevz, the necessary condition for successful adaptation of the child in a new family is mutual compliance of the role expectations of the child and adoptive the parents, taking into account the influence of the child's previous life experience on the identification process with the family. The neglected children in a new environment tend to the same identity, which provoke conflicts and withdrawal from the new family. It was the lack of psychological assistance to adoptive parents and children during the period of the child's adaptation to life in a new family that led to the emergence of the problem of returning children from foster families to boarding schools, from where they again run into the street ${ }^{33}$.

It should be noted that not every neglected child can effectively adapt to the situation in a new family, it depends on the type of neglect, the degree of maladjustment and the specifics of personality deformation, this must be considered when setting up a neglected child in a foster family.

Thus, currently under a lot of activities to prevent and overcome the neglect of children: a legal framework has been created for working with crisis families and the social protection of the children in difficult life situations; there is a network of centers for social and psychological rehabilitation for the minors.

\section{CONCLUSIONS}

Neglect is the complex socio-psychological phenomenon that arises in the interpersonal social-psychological system "children-parents" and manifests itself in the destruction of the emotional connection between the child and the parents, in the absence of care, positive influence on the part of the parents, and lack of control over the behavior and activities of the children. The emergence and distribution of the category of the neglected children is associated with the political and economic development of the

\footnotetext{
${ }^{33}$ Бевз Г.М. Прийомні сім’ї: оцінка створення, функціонування та розвитку. Київ: Главник, 2006. 112 с.
} 
country, the functioning of its social and legal system, and also depends on the degree of development of public morality and social protection of the family institution.

The alienation of the children from the family and their exit to the street primarily occurs in the dysfunctional families and the crisis families. Features of the social situation of development determine the specificity of socialization and the formation of the personality of the neglected children and teenagers. It should be noted that in the category of street children can get both from disadvantaged families, as well as from external stable families and children who do not have families. The definition of categories of the neglected children creates the prerequisites for a differentiated approach in providing them with social and psychological assistance and identifying ways of their re-socialization.

Social services focus on the organization of the work to improve the conditions of the family upbringing in families that belong to the social risk group. Currently, there is a certain system of correctional and rehabilitation work with minors who are in a difficult life situation. This system includes various state and public organizations, multidisciplinary centers, which, within their competence, carry out measures for the prevention and overcoming of neglect among minors.

\section{SUMMARY}

In the article it was considered the actual social problem of child neglect. On the basis of theoretical analysis of the psychological literature it was refined the concept of «street children» «homeless children» and «neglect children». It was found that the neglect is the weakening or lack of supervision of the child by the parents that can be one of the stages of personality desocialization and the transition to the state of homelessness, which is characterized by complete separation of the minor from the family and is connected to the loss of permanent residence. It is set that not only the antisocial families, but also the families with the conflict relations or with the wrong type of education are the factors of child's neglect. The attention to the consequence of the children' neglect is drawn to violation of the process of socialization, which is manifested in the social disadaptation and in the various types of deviant behavior of minors. It was concluded that it is necessary to implement the differentiated approach in the provision of socio-psychological assistance to the neglect children and to identify the ways of their resocialization. 


\section{REFERENCES}

1. Бартол К. Психология криминального поведения. СПб.: прайм-ЕВРОЗНАК, 2004. 352 с.

2. Бевз Г.М. Прийомні сім’ї: оцінка створення, функціонування та розвитку. Київ: Главник, 2006. 112 с.

3. Berg T., Vink C. Child and Youth Social Care Systems Abroad Lessons on strategies and systems from England, Germany, Norway and Sweden. The Netherlands Youth Institute. 2009. P. 64.

4. Главник О., Комарова Н. Діти вулиці: хто вони і як їм допомогти. Київ: Главник, 2006. 112 с.

5. Горобець I. В. Механізми державного управління у сфері протидії дитячій безпритульності та бездоглядності в Україні: автореф. дис. на здобуття наук. ступеня канд. держ. упр.: 25.00 .02 «Механізми державного управління». Івано-Франківськ, 2012. С. 13.

6. Domestic Violence Perpetrator Programs in Europe, Part I: A survey of Current Practice. International Journal of Offender Therapy and Comparative Criminology. 2012. № 10. P. 56.

7. Захист дітей, які потребують особливої уваги суспільства [Електронний ресурс]: статистичний збірник за 2017 рік. Державна служба статистики України [відп. за вип. О.О. Кармазіна]. Київ: ДССУ, 2018. 77 с.

8. Капська А.Й. Організація і технології соціальної роботи 3 дітьми вулиці. Київ: Інтернаціональний Союз. Ліга соціальних працівників України, 2004. 260 с.

9. Ковчина I.M., Вивчення досвіду соціально-правового захисту дітей та молоді у США та Канаді. Науковий часопис НПУ імені М.П. Драгоманова Серія 11. Соціологія. Соціальна робота. Київ, 2007. C. $63-73$.

10. Кубіцький С. Історія соціальної роботи в зарубіжних країнах: навчальний посібник. Київ: ДАКККіМ, 2009. 298 с.

11. Лактионова Г.М. Инновационные формы опеки детей: международный и национальный опыт. Київ: Науковий світ, 2011. 161 с.

12. Максимова Н.Ю. Психологія соціальної роботи із проблемними сім'ями: навч. посіб. Київ: ВПЦ "Київський університет", 2017. 463 с.

13. Мітіна С.В. Соціальні чинники бездоглядності підлітків. Вісник Київського національного університету імені Тараса Шевченка Київ, 2013. № 1(7). С. 74-77. 
14. Мустаева Ф.А. Основы профилактики безнадзорности и беспризорности несовершеннолетних. Москва, 2003. 456 с.

15. Оржеховська В.М. Дитяча бездоглядність та безпритульність: історія, проблеми, пошуки: навч. посібник. Київ: Логос, 2004. 172 с.

16. Пєша I.В. Особливості функціонування дитячих будинків сімейного типу як сімейної форми опіки над дітьми-сиротами. Збірник наукових праць Херсонського державного пед. ун-ту. Херсон, 2006. Вип. 13. С. 189.

17. П'єша I.B. Соціальна допомога безпритульним та бездоглядним дітям, що надається закладами та організаціями різного підпорядкування. Український соичумм. 2007. № 5-6 (22-23). С. 49.

18. Про забезпечення організаційно-правових умов соціального захисту дітей-сиріт та дітей, позбавлених батьківського піклування. Закон України (зі змінами від 08.02.2018 року) Відомості Верховної Ради України. 2005. № 6. Ст. 147.

19. Реалізація конвенції ООН права дитини в Україні: досягнення, проблеми, перспективи (за період 2009-2016 р.p.). Державна доповідь про становище дітей в Украӥні. Київ: Міністерство соціальної політики України, 2016. 164 с.

20. Селиванова О.А. Личностно значимые условия реинтеграции „уличного” подростка. Москва: Генезис, 2004. 239 с.

21. Система державних органів соціального захисту прав дітейсиріт та дітей, позбавлених, батьківського піклування. Держава $i$ право. [упоряд. О.М. Ноздріна]. Київ: Інститут держави і права НАН України, 2006. Вип. 33. 270 с.

22. Ткач Р.М. Соціально-психологічні чинники, що зумовлюють схильність дітей до бродяжництва. Актуальні проблеми психологї: збірник наук. праць Ін-ту психології ім. Г.С. Костюка АПН України. Київ, 2006. T. VIII, ч. 8. С. 298-303.

23. Удовенко Ю.М. Система служб соціально-психологічної підтрімки дітей-жертв насильства (вітчизняний та зарубіжний досвід). Актуальні проблеми психологї: збірник наук. пращь Ін-ту психології ім. Г.С. Костюка АПН України. Київ, 2006. Т. VIII, вип. 2. С. 336-342.

24. Юрченко Т.А. Соціально-психологічний підхід до проблеми бродяжництва дітей. Актуальні проблеми практичної психології: зб. наук. працьь. Херсон, 2006. С. 280-281. 
Information about the author: Mitina S. V. Associate Professor at the Department of Psychology and Pedagogy of the V. I. Vernadsky Taurida National University 33, Ivana Kydri str., Kyiv, 01042, Ukraine mitina.svetlana68@gmail.com Researcher ID: G-7268-2017 ORCID: 0000-0001-9520-0272 


\section{THE THEORETICAL-METHODOLOGICAL PROBLEMS OF GENDER-ROLE IDENTITY OF ADOLESCENTS}

\section{Osmanova A. M.}

\section{INTRODUCTION}

The continually changing living conditions in Ukraine and the modernization of the educational system lead to the necessity for studying the classical system of pedagogic and education. The aims of this studying are a search for new approaches to the education of development generations, creating conditions for the formation of children as fullfledged personalities and as representatives of a certain gender.

A problem of sex-role socialization of adolescents has appeared in psychology for recent decades. In the context of this problem, the question of the formation of notions about sex-role behavior of adolescents starting from preschool age is considered. Reframing of the relationship of genders, self-awareness as a representative of a certain gender, identification of man or woman, and choosing a behavior model by their sexual status carry out in this period.

The study of problems concerning the teenager's characteristic as a representative of a certain gender, the forming of his sex-role behavior contributes to the most harmonious development of personality, individuality, interests, and the system of representing oneself as a man/woman. These characteristics have specific needs, motives, value orientations, and corresponding to these entities forms of social behavior.

Age of adolescence is the determinative period in the formation of a personality. It is characterized by a reframing of the relationship of genders, sex-role behavior as a value that affects the formation of the female / male individuality of the adolescent, his future intimate and social life, family happiness.

This is the time when a subject seeks to expand and clarify the meaning of his/her "I am". This age period period is an important stage in the formation of gender identity, because it is at this age that an active awareness of the essence of their attitudes towards other people and of 
oneself takes place, and sexual self-determination is expanded and clarified.

As scientists emphasize, the formation of gender identity occurs precisely in adolescence which is an internal experience of their sexual identification, the acquisition of a gender-role and modeling to it, a peculiar unity of sexual self-awareness and behavior. Age of adolescence determines the further development of the personality, orientation to the true samples of I am - a man and I am - a woman in the new changing conditions. The formation of gender self-consciousness is included filling of their egalitarian values, sexual "I-concept" and gender-role identification.

The different aspects of gender are considered in national science. Thus, the works of T.L. Bessonova, M.Y. Boryshevsky, O.L. Kononko, G.S. Kostyuk, O.G. Sukhoelova are devoted to the formation of sexual consciousness and identity of a person at different age stages. The questions about the development of the psychological gender are studied in the works of V.V. Avramankova, T. V. Govorun, O.M. Kikinezhdi, A.A. Palia, T.I. Yrefova. The interpersonal relations are highlighted in the works of V.E. Kagan, Y.L. Kolominsky, L.I. Moroz. In the works of Y.E. Alyoshina, V.O. Vasyutinsky, A.S. Volovich, T.S. Gurlieva, I.V. Romanova, V.G. Romanova, the problems of gender-role identity of adolescents were studied.

At the same time, the urgent issues remain a problem of factors of the formation of gender identity identification among adolescents and under the influence of which factors the formation of gender identity identification of adolescents is. The traditional system of values is characterized by a dichotomous vision and a new, egalitarian, is characterized by a combination of interchangeable qualities. For this reason, the role of the social environment (family, peers, and teachers), the content of specialized education, the content of teaching modes, in particular, school textbooks, and internal motivations as factors of gender identity of a person obtain specific meaning.

\section{Psycological theories about the mechanisms of gender-role identiy of adolescents}

In the identity space of a person, the understanding that this world is system integrity is essential. 
The history of the development of the concept of Identity is connected with the development of general philosophical and psychological approaches to the problem of individual rights formation. This is connected with searching for the reason for existence, awareness of its place and role in society, his/her similarity and distinction from other people.

The identity problem is complex and multi-disciplinary. The evolution of the concept of Identity has a specific history in science since its study took place in various sciences - philosophy, sociology, psychology, anthropology, cultural studies, ethnology, etc.

The term Identity was used in the social and humanities sciences and parallel with philosophy for a long time.

The content of the evolution of the concept of Identity in philosophy has a peculiar history that affected its modern understanding. The concept of Identity is philosophical and refers to metaphysical issues. In this meaning, the concept the Identity is used e.g. by B. Spinoza. According to B. Spinoza, the Identity "is not the cause of the Universum but itself is the Universe"1.

The concept of Identity is studied also in psychology. Psychologists who discuss the problem of identity tend to consider two aspects: personal identity and cultural identity.

The current psychological studies of the gender problem are based on the gender factor that is present both at earlier and the latest age period of human life. That means this exists as an extremely stable and constant characteristic of human ontogenetic evolution. The human ontogenesis is revealed as a continuous change of one age period to another and this is one of the permanent characteristics of each of them. The gender is the first sign which an individual enters by the "human realm" with. The object of the study "sex" of the complexity and ambiguity is due to the mosaic of biological, social, and individual-personality aspects that appeared in these prospects and predetermine his internal contradictions ${ }^{2}$.

It can be distinguished in three main areas of research related to gender issues in the framework of psychological science. The first area, socalled gender is based on the study of objectively existing sexual differences in psyche and behavior. The concept of Gender means sex as a

\footnotetext{
${ }^{1}$ Спиноза Б. Избранные произведения [Текст] : Пер. с лат. / Б. Спиноза. - Ростов-на-Дону : Феникс, 1998. $-606 \mathrm{c}$.

2 Москаленко В.В. Гендерна роль як фактор статеворольової соціалізації // Теоретико-методологічні проблеми генетичної психології: Матер. Міжнар. наук. конф. - К. : Міленіум, 2002. - Т. 1. - С. $128-136$.
} 
social phenomenon, like all social that is formed over the biological sex. The sociological and cultural factors in the formation of sexual differences are studied in psychology that should be reflected in scientific research tools. This gives the foundation to claim that in defining the differences between male and female qualities in psychology is better to give preference to the concept of Gender. So, Gender is a socio-psychological concept that defines the status of a person from the prospects of masculinity or femininity. Masculinity is a set of features that distinguish a man from a woman. Femininity is a set of features that distinguish a woman from a man.

The main subject of research in the second area is the subjective stereotypes of masculinity and femininity within a particular Ethno and social culture. The third area of studies is devoted to the formation of gender-role identity and identification as one of the aspects of personal development which is understood as the unity of behavior and selfawareness of an individual who relates to a particular gender. Gender-role identity is a valuable identification of oneself with representatives of a certain gender, peculiar of their behavior and performance of social roles. Socio-sanitary regulations and norms of behavior are internalized by the subject of activity in the process of ontogenesis, gaining subjective understanding, experiences of gender-role which demonstrates in the unity of behavior and self-consciously ${ }^{3}$. Gender-role identity is formed gradually in the process of gender-role socialization. The critical stage of the formation is the age of adolescence. The final formation of it takes place during this period.

The term Identification (from Latin identificare - identify) was introduced by S. Freud for the first time in the theory of him it has two meanings: 1) on the one hand - as the formation of the identity between images that are born in hallucinations dissatisfied instincts, on the other hand - as images of real objects that really satisfy human needs; 2) in the second sense, the identification is understood as one of the essential mechanisms for the formation of personality - the moral authority of super-ego. To overcome instincts and thereby avoid punishment, a child identifies himself partially with his parents or authoritative people, and this

\footnotetext{
3 Кізь О.Б. Гендерна соціалізація депривованого юнацтва:дослідження соціально-психологічних детермінант // Зб. матеріалів Всеукр. науково-практ. конференції. - Тернопіль : “Богдан”, 2003. C. $78-85$.
} 
way internalizes their values, moral norms, prohibitions, and appropriate forms of behavior ${ }^{4}$.

The authors Andreeva G.M. and Petrovsky P.A. consider the term Identification in psychology as a mechanism of socialization, shown in the acceptance of the individual social role in the process of entering the group, the awareness of group membership, and the formation of social institutions 5 .

According to the theory of behaviorism, G.M. Andreev confirms that the identification is the conscious or unconscious copying of attributes or characteristics of others. A positive contribution to the development of the theory of the identification was the introduction of cognitive aspects in the analysis of this process, or rather, recognition of it as consciousness. In the theory of behaviorism, components of identification are taken into account not only biological and psychological but also social. The identification this is the result of the necessity for communication at all levels (unconscious and conscious), direct experience of a subject of identity with an object ${ }^{6}$.

In Psychological Dictionary by the edition V.P. Zinchenko, B.G. Mescheryakova identification is defined as a multiple-meaning psychological concept:

"1) Modeling (unconscious as a rule) oneself to a significant other as a sample based on an emotional connection with it;

2) Identifying oneself with the character of imaginative writing, through which penetration into the semantic content of the work and its aesthetic experience occurs;

3) The mechanism of psychological protection consists of the unconscious likeness of the object;

4) The projection - attribution of his features, motives, thoughts, and feelings to another person;

5) Identifying oneself with some social group or community, accepting of its goals and values, and becoming aware of its membership",

In the psychological literature, the terms Identity and Identification are used sometimes synonymously. E. Erickson considered identity formation

\footnotetext{
${ }_{5}^{4}$ Фрейд 3. Введение в психоанализ. Лекции. Пер. с нем. М.: Наука, 1989. - 455 с.

5 Андреева Г.М., Петровская П.А., Богомолова Н.Н. Современная социальная психология на Западе (теоретические направления). - М.: Изд-во МГУ, 1998. - 271 с.

${ }_{7}^{6}$ Андреева Г.М. Социальная психология. - М. : Наука, 1994. - 324 с.

${ }^{7}$ Психологический словарь / под ред. В. П. Зинченко, Б. Г. Мещерякова ; 2-е изд., перераб. и доп. - М. : Педагогика - Пресс, 1996. - 440 с.
} 
as a synthesis of previous personality identities noted that identity can not be reduced to a set of identities ${ }^{8}$.

B.D. Parygin uses the term Assimilation refers to the identification. He understands the identification of the mutual assimilation of people to each other ${ }^{9}$.

M.Y. Boryshevsky considers identification as a process by which one subject is likened to another by taking on the values, settings and life experience of a model, and its specific forms of behavior ${ }^{10}$.

B. Porshnev asserts the mechanism of group identification is demonstrated that a person is formed by a system of rules and norms which s/he identifies with. Each person refers to a particular social group, identifies his/her "I am" with the other "I am" in the general "We are". As a result, the members of the group of the psychological mechanism of identification have a sense of "We are" that is, that confirm a certain social set and causes its members' similar motives and acts of conduct ${ }^{11}$.

According to the findings of an American researcher P. Massen, identification is different from mere imitation as follows:

1) When identifying digested non-discrete acts of behavior and integrated pattern of behavior;

2) Identification occurs spontaneously without direct reinforcement;

3) The behavior that the individual acquires during the identification process is quite stable;

4) Identification is based on an intimate personal relationship with a model.

Gender identification is most deeply studied in the psychoanalysis of $Z$. Freud who is one of the first scientists emphasized the importance of the sexual sphere in the human psyche. He tried to trace the path of sexuality development in the ontogenesis of a person. In each of the stages of psychosexual development of personality by S. Freud, erogenous zones are established as a focus of his/her desire. The way they will be satisfied will depend largely on problems in the sexual behavior of an adult. The childhood lays the foundations of the psychology of sexuality especially an infant up to six years when the individual passes three of the five stages of

\footnotetext{
8 Эриксон Э. Идентичность: юность и кризис / Пер. с англ. ; общ. ред. и пред. А.В. Толстых. - М. : Прогресс, 1996. - 341 с.

9 Парыгин Б.Д. Социальная психология: проблемы методологии, истории и теории. - СПб. : ИГУП, 2011. - 592 c.

10 Боришевський М.Й. Психологічні питання статевого виховання учнів // Проблеми викладання курсу етика і психологія сімейного життя. - К. : Наука, 1990. - С. 13-29.

${ }^{11}$ Поршнев Б.Ф. Социальная психология и история / Поршнев Б.Ф. ; 2-е изд. - М. : Наука, 2009. - 232 с.
} 
psychosexual development. If the previous stages of a person's psychosexual development were associated with their physical "I am", then from age of adolescence the child's narcissism or auto-erotism disappears, giving way to the direction of sexual interests to other people. They are as objects of sexual satisfaction that contribute to the development of sensuality, attraction, needs, interests of an adult that is, "secondary sexuality". According to the studies of S. Freud, an individual passes in his/her development from one psychosexual stage to another only in ideal conditions of upbringing ${ }^{12}$. He considered that a person develops in that way harmoniously and fully when she follows the mentioned above models and her sexual identification is not violated.

Consequently, identification is interpreted in psychoanalysis as an unconscious process of imitating behavior or certain qualities of the person which an individual identifies with. The traditional psychoanalytic concept ascribes the main role in sexual differentiation to biological factors and considers its basic mechanism of identification of a child with parents.

G. Freud, like her father, emphasizes that a child simulates the behavior of adult representatives of his/her gender unknowingly, primarily of his/her parents. G. Freud pays attention to the complex mechanisms of protecting his "I am" in her works as well. This mechanism includes introjection and projection. Projection is the process of ascribing by a subject to another person his/her thoughts, rice, motives, and feelings that cause the subject to feel guilty and anxious. Introjection is a personification of the personality traits of another person in the individual form. G. Freud described youth as a period of internal conflict, mental unbalance, and restless behavior. The contradictory behavior of adolescents is caused by internal conflicts that are accompanied by sexual changes in the body. One of the most noticeable changes occurring in the puberty period is the increase in instinctive attraction. The main source is puberty which is accompanied by an increase of interest to the sexual area. Impulses "It is" are aggravated and give rise in adolescence and challenge to "I am" and "Over me" of an individual. Thus, in the puberty period, it seems that the infantile sexuality and aggressiveness of early childhood are reviving. It is necessary that "Over me" has enough time to develop in the latent period for the harmony between "It is", "I am" and "Over me",

\footnotetext{
12 Фрейд 3. По ту сторону принципа удовольствия. Пер. с нем. / Сост., послесл. и коммент. А.А. Гучнина. М.: Прогресс, Литера, 1992. - 567 с.

${ }^{13}$ Фрейд 3. Введение в психоанализ. Лекции. Пер. с нем. М.: Наука, 1989. - 455 с.
} 
K. Horney has made a significant contribution to understanding the role of psychosexual development of a child, in the occurrence of sexual dysfunctions, and pathopsychological conditions of an adult. According to her opinion, the parental and children's relationship forms anxiety, fears, and fears of a child at an unconscious level. The author believes that the identification mechanism with his/her father is the cause of the appearance of masculinity in women. Two factors inhibit the formation of a stable libido fixation of a father. Firstly, it is a frustration in a father. Secondly, these are anxiety and feelings of guilt towards the mother for incestuous fantasies. Therefore, the heterosexual libido regresses frustrating and a girl goes from femininity and gains masculine features - complex masculinity is formed ${ }^{14}$.

According to K. Horney, 1) femininity arises on the path of transformation of masculinity; 2) to refuse femininity is possible only through the acquisition of masculine feature; 3 ) female masculinity is secondary in its genesis in relation to femininity; 4) the presence of male feature in a woman is the result of a deviation from normal development.

According to K. Jung's concept, the concept of bravery-femininity is regarded as indicators of the maturity-immaturity of an individual. As a result, the feminine identity is the primary that an individual should be breaking free in the process of his/her development. There are relations of opposition between these structures that can vary from confrontation and struggle to harmony. The feminine in the concept of $\mathrm{K}$. Jung is considered as a characteristic of a neurotic relationship with a mother. An individual with infantile guidance, strong parental imago reveals weakness, helplessness, attachment to the mother and self-identification with her.

Another aspect of gender-role identity in K. Young's concept is related to the archetypes of Anima and Animus (a female part in a male and a male in a female). If a man feels that his mother has hurt him, his Anima will often be in a depressed and annoying mood, a sense of uncertainty and insecurity, abusive, and injurious. If a man can overcome such negative adversities that cause pain then it may even become in his favor and enhance his masculinity. On the other hand, if a man had a positive experience in dealing with his mother, this could also affect his Anime. A man becomes either "feminine - sensual" or sensitive untouchable. K. Jung noted that the cultural stereotype of society focuses

${ }^{14}$ Хорни К. Женская психология. - СПб. Питер, 2011. - 382 с. 
on the development of the appearance of only one face "I am". However, a person is approaching the natural "I am" only discovering the opposite sexually-oriented qualities ${ }^{15}$.

In the concept of "striving for power" by A. Adler, the weakness is equal to femininity and force - masculinity. At the same time, both genders attempt to overcome the feeling of disability and inferiority that is demonstrated in the form of hyper compensation as a "masculine process".

E. Erickson considers psychosocial identity and defined it as a necessary condition for preserving the individual's health, his/her inner integrity, and stability is an important personal need. He distinguished the term psychosocial identity as a result of interaction between society and personality. Studying the approaches of identification, E. Erickson pays attention to a problem of the formation of personality, emphasizing the importance of the fifth stage of development the crisis of adolescence. The re-orientation of a person from the family to society as a whole occurs during this period.

An important place in the psyche of a young person is his/her interest in the thoughts of other people to what they think of themselves. E. Erickson believes that communication with the environment that occurs in this period varies between the positive pole of the identification "I am" and the negative pole of "confusion of roles". In other words, a young man faces the task to unite all that he knows about himself as a student, son, athlete, friend, etc.

All these roles he should combine into one unit, comprehend it, unite with the past and project the future. If a young person copes successfully with this task of psychosocial identification, then he will have a sense of who he is, where he is, and where he goes. If he cannot solve the problem of identification and to define his "I am" due to a difficult childhood or a difficult financial situation, then he begins to show symptoms of confusion of roles and uncertainty about who he is and which environment he belongs to. Such confusion of roles leads to conflictual behavior, antisocial actions, and the growth of crime among young people.

So, according to E. Erickson, identity is a characteristic feature of an individual, "internal identity and continuity" is synthesized with the desire to integrate it with social structures ${ }^{16}$.

\footnotetext{
${ }^{15}$ Юнг К.Г. Архетип и символ. - М. : Рениссанс, 1991. - 304 с.

16 Эриксон Э. Идентичность: юность и кризис / Пер. с англ. ; общ. ред. и пред. А.В. Толстых. - М. : Прогресс, 1996. - 341 с.
} 


\section{Socio-psychological bases of formation of gender-role identity of adolescents}

A family is an educational cradle of a person. It forms not only the physical but also the social life of a child. Therefore it is the primary, most influential and long-term approach of the formation of gender-role identity of the child at all stages of child development.

Considering the educational strategies of parents about teaching a child his/her gender-role, parents act in this case primarily as members of a certain cultural tradition regarding the place of a man and a woman in society. It includes an established system of differentiation of gender-roles that is the gender division of labor, specific gender-regulations, the rights and responsibilities of men and women, and the associated system of stereotypes of masculinity and femininity representations of what should be men and women.

The uniqueness of the family's influence the development of gender identity is confirmed by those children who are deprived of a family. There are the following images of masculinity. Femininities are formed primarily because of the inclusion in every day family's relationships, direct imitation and assimilation of the experience of performance of fathermother roles, through the correlation of his/her behavior with gender-role regulations. Charity children deprived of permanent parental care, usually synthesize images of masculinity/femininity from media, relationships with adult educators, and experience with peers. The limitation of their social experience impoverishes the range of social situations in children development. This simplifies the system of interpersonal relationships important for the child and thus distorts the logic of the formation of the gender-role image "I am".

Regarding the psychological differentiation of gender, A. Adler observes the following. The normal, harmonious interpersonal relationships undoubtedly are based on adequate attitudes towards the images of masculinity-femininity. It depends not only on how much time the parents give to the child, raising his/her as a woman or a man but first of all how much a person is developed socially, his/her ability to contact with others is formed, understanding others, and to "feeling" others.

The family life is a life sphere that set high conditions of psychological culture, responsibility, level of development of selfreflection, marital, maternal and parental roles. Children from families have the opportunity to participate in complex, diverse activities, and 
communication of adults. The assimilation of all complex elements of activity, the development of the internal plan of actions goes beyond the educational situation and is included in the context of activities directly attractive to the child. Charity children deprived such a variety of emotionally-rich interaction with adults.

Some aspects of the family, including ethical, psychological, and pedagogical were covered in the studies of M. Olexyeva, T. Govorun, O. Kikinezhdi, O. Kiz, Z. Kisarchuk, V. Kravets, O. Nasonova, V. Stakhnevych, etc. Such important aspects of the development of the sexual consciousness of depressed adolescents as the formation of representations about the basic functions and types of the family, the relationships between parents and children did not find a deep theoretical and experimental substantiation, and in the future still remain poorly researched in the problems of age and pedagogical psychology.

To understand the meaning of differential gender identification, it is necessary to trace its dynamics through the prospect of family relationships. I. Kon considers that knowledge about his sexual identity is formed at the age of 1.5 years and since then plays the role of the most constant, core element of self-consciousness. Each age stage brings the changes in the content of this identity which is primarily referred to the mental and intellectual development of the child.

Researching the age aspect of identifying children from 3 to 16 years old from complete families, O.I. Zakharov showed a clear difference in the sensitivity of children of different ages and sex to the influence of the parent of the same sex. In his opinion, children of both sexes who are raised without a father, more often than children from a complete family, demonstrate conflict in behavior, mood changings, stubbornness, attempts to stand out, dependence and passivity.

The researcher notes that the age of the most intense identification with the parents of the same sex is 5-7 years for boys and a longer period 3-8 years for girls. The identification of girls with same-sex parents from boys has the following characteristics: the greater the intensity of the identification process that is girls choose the role of the mother more often than boys choose the role of the father; the greater importance of identification for girls emotionally warm relationships with the mother; the greater dependence of girls identification from the nature of the relationship between parents, when the mother-father conflict negatively affects the identification of girls with their mothers. The process of identification is suspended during the period of 
intense self-development - from 9 years for girls and 10 - for boys. This leads to emancipation from parental authority.

The psychological studies prove that a 3-4-year-old child distinguishes consciously between genders of people around him/her but more often refers it to external signs only. A 6-7-year-old child realizes finally the invariability of sexual identification. Thus, even in the period of preschool childhood, children are sufficiently aware of gender differences in toys, clothing, activities, objects, and occupations. As the child grows up, s/he notices the differences between the sexes. As a rule, s/he has increased attention to role models of the same sex as $s / h e$ is and s/he wants to be a "real and the best" boy or girl ${ }^{17}$.

According to E. Maccoby and C. Jacklin, children receive information from representatives of both genders but they are inclined to reproduce only those patterns that are inherent in their gender. According to the authors, this model accurately reveals gender-role behavior. Therefore, even the children of those parents who demonstrate the atypical behavior of a gender stereotype can perceive and imitate models typical of their gender-roles. The gender stereotypes are as approaches for maintaining gender-specific differentiation.

As researched I. V. Telniuk, the majority of parents (83\%) consider it necessary to educate their children in the context of sexual differentiation, the rest hesitate to identify the right ways ${ }^{18}$.

In the work of V.O. Vasyutinsky, there is evidence that the genderrole identity of children is not so much the result of conscious and purposeful interference by parents as the derivative of the whole intrafamily atmosphere. The author pays attention to the differences in the identification of maternal and parental love of the child. Maternal love is unconditional, global, and permanent. Certainly, because the mother loves his/her child in spite of everything, she loves it because it's her baby. This love demonstrates in each situation regardless of circumstances. This is constant and lasts through the whole life. At the same time, the father loves the child more distantly. In his opinion, he loves his/her when s/he has something to be loved to when s/he justifies his hopes and ideas. In the author's opinion, it's harder for men to love the child "for no reason", just

\footnotetext{
17 Захаров А.И. Психологические особенности восприятия детьми роли родителей // Вопросы психологии. - 1982. - № 1. - С. 59-68.

18 Тельнюк И.В. Индивидуально-дифференцированный подход к организации самостоятельной деятельности девочек и мальчиков 5-6 лет в детском саду: автореф. дис. ... канд. наук: - СПб., 1999. - 20 с.
} 
because it's their child. Maternal love is selfless but also subjective. The father can assess the nature objectively and abilities of the child ${ }^{19}$.

I.S. Kon focuses on the differences in parental and maternal influence on the formation of the child's characteristics. The father is perceived and is indeed tougher and authoritative than the mother, especially as regards boys and young men. Psychological intimacy with his father is observed less often than with his mother. The influence of the father on the upbringing of children in most families is lower than the influence of the mother ${ }^{20}$.

According to S. Bem, educating the "a real boy", the parents approve of the features of practicality, perseverance, self-confidence, and stiffness. "True girl" is educated gentle, dependent, sensual, coquettish and impractical.

Petrovsky O.V. believes that when children are relative free from the stiffness of gender typing, they demonstrate a richer behavioral set and more prosperous psychologically. Understanding the gender-role by a boy or girl facilitates in the future their socialization in society. At the same time, we find that children whose behavior is strictly suited to the requirements of their gender-roles are often characterized by lower intelligence and less creative abilities ${ }^{21}$.

Authors Y.E. Alioshina, O.S. Volovych believes that the barriers for boys' identification are a long term of contact between a boy-son with his mother that makes his father an undesirable, little-known object for identification. This can happen even when the child is afraid of his father because of his excessive severity, rudeness - then he will desire to get the needed warmth and attention from his mother, neurotic dependent on her and her behavior style ${ }^{22}$.

As a result, the identification is primary with the feminine mother. The status of the child reflects traditionally a female feature- dependence, subject position, passivity. Thus, a boy faces a difficult task in future development - to change the primary female identification to masculine. However, most of the behavior models that the boy faces in the process of formation of gender-roles are feminine: nurseries of children garden,

\footnotetext{
${ }^{19}$ Васютинський В.О. Особливості статеворольового самовизначення хлопчиків-підлітків із неповної сім’ї: Автореф. дис. ... канд. псих. наук: 19.00.07 - К., 1992. - 19 с.

${ }^{20}$ Кон И.С. Психология половых различий // Вопр. псих. - 1981. - № 2. - С. 47-57.

21 Петровский А.В. Личность. Деятельность. Коллектив. - М. : Политиздат, 1982. - 255 с.

22 Алешина Ю.Е., Волович А.С. Проблемы усвоения ролей мужчины и женщины // Вопросы психологии. - 1991. - № 7. - С. 74-82.
} 
doctors, and teachers. Therefore, boys have limited identification of a true male gender-role and the behavior that it responds to.

According to R.F. Harley, this leads to the idea that boys have to build their own sexual identity, mainly based on denial and negative attitudes towards "women's" world: not to be like girls and not to engage in women's activities. This explains the fact that girls the gender-role identity is less conflictual and continuous.

According to Y.M. Nabiulina, identification is more successful of girls: $43 \%$ of girls compared to $8 \%$ of boys have a high degree of identification with the parents of their gender. According to the author, there is inadequate, misunderstood identification more often of boys that is related to the absence of a father in the family ${ }^{23}$.

F. Parsons saw the role of the father in helping his son overcome the primary dependence on the mother from early childhood. There is the destruction of the primary identification of the boy with his mother which occurs with the help of his father, who maintains his son's tendency to depreciate the entire female.

The traditional male role affects paternity adversely and the frequency of emotional contacts. The demonstration of tenderness, affection, and care are not available for many parents due to the dominant gender stereotype of masculinity which denies the expressiveness of relationships as a deviation from the male role.

G. Russell proved that androgenic parents more actively and constantly engaged with their children that are those who have the same male and female peculiarities of behavior.

Gender stereotypes play an important role in parent's strategies in the education of children, the expectations of their success in learning, the choice of the future profession, etc. J. Eccles argues that parents keep gender-differentiated awareness of their children's abilities and can socialize gender differences of self-perception, interests, and skills of children through educational impacts. It has been proved that parents observe gender-differentiated awarenesses of their children's abilities, even when their different-sex children receive the same grades at school and have equal grades taking standardized tests. J. Eccles refers to studies that have proven that parents explain the successes of boys and girls in a

\footnotetext{
${ }^{23}$ Набиулина Ю.М. Проблема полоролевой идентификации в семейном аспекте // Психология XXI века: Тезисы международной межвузовской научно-практической конференции студентов и аспирантов. - СПб. : Изд-во СПб. ГУ, 2001. - С. 238-239.
} 
particular school subject for various reasons: parents of boys who succeed in mathematics believe that such a result is achieved through their abilities, while the parents of girls are excellent mathematical achievements associated with their diligence ${ }^{24}$.

There is a certain model that parents have laid down and which is based on gender stereotypes. According to this model, gender stereotypes influence significantly:

1) Why parents attribute the school achievements of their children (abilities, diligence);

2) The emotional reactions of parents about the success of children in various fields of knowledge;

3) The importance that parents attach to their children with different knowledge and skills;

4) The advice given by parents to children in obtaining by them certain knowledge and skills;

5) Those activities to which parents involve their children and the toys that they buy them.

The gender-role of adolescents as one of the most common approaches for teaching gender-role behavior is confirmed and specified in communication with parents. I. Kon identifies the following approaches:

1) Reinforcements: encouraging certain behaviors parents consider to be correct and punishing for deviancy, parents enroot into a child's consciousness a certain system of rules, the observance of which becomes a habit eventually;

2) Identification: the child follows the parents, strives to become as they are;

3) Understanding: knowing the inner world of a child and meeting his/her needs, by that the parents form their personal qualities;

4) The role-complementarity: for instance, if parents have no qualities in a family, these qualities are produced by a child, circumstances require (in a family where a mother is helpless, the role of the hostess serves an elder daughter);

5) The approach of psychological counteraction: a child whose will is strictly limited can create an attraction to independence and that one whom everything is allowed may grow up a dependent person ${ }^{25}$.

\footnotetext{
${ }^{24}$ Eccles J.S. Gender roles and women's actievement-related decisions // Educational Researcher. 1986. N 15. - Pp. 15-19.

${ }^{25}$ Кон И.С. Психология половых различий // Вопр. псих. - 1981. - № 2. - С. 47-57.
} 
The studies of A.Y. Vargas proved that acceptance or neglect of a child is the main place in the structure of parental attitude. It is emphasized that indeed a complete and harmonious family is instrumental in the formation of the child's psychological sex for the formation of adequate gender-roles, stimulates the process of identifying a child with a person of his/her gender - primarily with his/her father or mother ${ }^{26}$.

According to Western authors M. Lewis and L. Rosenblum, mothers relate to the behavior of sons more reluctantly and allow them to be more aggressive than girls. Boys are punished physically more often. Y.E. Aleshina and O.S. Volovich have found in their studies that parents demand a lot from their sons, as a result, receive greater distance their sons from parents ${ }^{27}$. As the study of A.S. Baranik, the mothers are responsibilities for the daughters and the father - for the sons ${ }^{28}$.

O.B. Chirkova has proved that a father plays a more significant role in forming the motivation in achievements of daughters: the daughters of mothers who work at institutions or a factory are more motivated in a career than their peers whose mothers are housewives ${ }^{29}$.

According to V.P. Svetlakova and M.O. Tokmakova, the interesting is the fact, that choosing the profession children are consulted more often with their mother than with their father ( $40 \%$ and $23.7 \%$ respectively $)^{30}$.

There is an argument as soon as children become able to identify their gender, they have the motivation to be or become like other members of the very first reference group in their lives - families. They begin to monitor carefully adult' behavioral patterns. On the other hand, their parents also direct their educational efforts to implant the sons and daughters of the model of behavior and the basic concepts of "gender" ideology. Their potential of gender representations and the demands of a society of socialization of women and men are involved in this process.

Thus, gender-role education in the family is differentiated noticeable by gender which creates unequal opportunities for representatives of

\footnotetext{
${ }^{26}$ Варга А.Я. Идентификация с родителями и формирование психологического пола // Семья и формирование личности: Сборник научных трудов / Под ред. А.А. Бодалева. - М. : АПН СССР, 1981. C. $10-15$.

27 Алешина Ю.Е., Волович А.С. Проблемы усвоения ролей мужчины и женщины // Вопросы психологии. - 1991. - № 7. - С. 74-82.

28 Баранник О.С. Влияние семьи на формирование тревожности у дошкольников // Ананьевские чтения - 99: Тезисы научно-практической конференции. - СПб., 1999. - С. 176-177.

29 Чиркова О.Б. Роль детско-родительских отношений в развитии ответственности подростков // Психология XXI века: Тезисы Междунар. межвуз. научно-практ. студенческой конференции. - СПб., 2000. - C. 193-195.

${ }^{30}$ Светлакова В.П., Токмакова М.А. Влияние родителей на выбор абитуриента // Ананьевские чтения2001 : Тезисы научно-практической конференции. - СПб., 2001. - С. 413-414.
} 
different sexes: in general, boys have more opportunities to expand their experience, to explore, and experiment. Activity, independence, and selfcontrol in a rivalry situation encourage. In the process of learning girls of gender behavior, her activities are limited, the emphasis is on the correct behavior, there is always parental control: work at home, closer to parents, frequent and unconditional help create for the girls a more canonized and predictable environment than that in which the boys live.

A school is a major aspect of social factors. The school is one of the most conservative systems. Therefore, some foundations reproduce patriarchal ideas about the purpose of men and women at the level of secondary school. They form different orientations for the further formation of gender-role identification of adolescents. The most popular and persistent features of a personality that are demonstrated in the social activity which is regulated by the role structure of society are formed at school in the process of education and upbringing. Girls and boys learn common values, gender instructions of teachers, and as a result, the inheritance of gender stereotypes becomes a part of their gender structure.

\section{CONCLUSIONS}

The analysis of the theoretical and methodological approaches in studying the problem of the formation of gender-role identity allows us to outline a set of conceptual conclusions.

1. In psychological and pedagogical literature is given a significant place of the gender-role identity of a person. The most intense form of gender-role identity occurs in the age of adolescence. However, the problem of socio-psychological conditions that affect the formation of adolescents' gender-role identification is still poorly understood and very generalized. The analysis of the literary sources concludes that identification is always co with other people who can serve as a pattern for a short or long period. In the early stages, the approach of gender-role identity ensures the transfer of "personal" experience indirectly - through a personal example, imitation, and suggestion. The range of people from whom the sample-object of identification is selected expands at the later stages of the formation of gender-role identity. It is not only parents but also peers, teachers, etc.

2. The isolated social conditions conclude that family forms not only the physical but also the social life of a child. Therefore, this is the 
primary, most influential, and long-term active force of the formation of the gender-role identity of a child at all stages of its development. The analysis of scientific sources confirms that family upbringing differentiates based on gender and creates unequal opportunities for representatives of different genders.

3. School is a major aspect among social conditions for the formation of gender identity. The most widespread and persistent features of the personality which are showed in a social activity that is regulated by the role structure of society in the educational process and upbringing are formed in school.

4. In psychological and pedagogical literature, a significant place in the formation of the "I am-concept" of a teenager's personality which is a kind of framework that gives various psychological demonstrations of a person a certain internal interdependence. It takes a significant place, directing it into a united place, so all of this becomes a basis, an example, a model for choosing by a boy and a girl of gendered behavior in meaningful spheres of life activity.

Based on the conducted theoretical analysis and generalization, a personality-gender approach to studying the conditions of the gender-role identity of adolescents is suggested. This is carried out through a set of principles.

\section{SUMMARY}

The theoretical and methodological analysis of the formation of gender-role identity of adolescents and the study of socio-psychological conditions affecting its formation are presented in this article.

1. Theoretical analysis of socio-psychological conditions of genderrole identity develops a methodological approach that corresponds to the research tasks most adequately. We use the personality-gender approach which is based on the principles: a) objectivity, parity, integrity in the study and development of gender-role identity; b) the development of gender consciousness and consciousness in activities that are necessary for a proper understanding of the demonstration and development "I amconcept" of a personality, and the development of its gender-roles; c) succession which involves the sequence in the transfer of gender knowledge to young people, their adequacy to the child's age; the gradual expansion of the information gender area in which the authority of the 
source of information (parents, teacher, psychologist, physician) is an important condition for the normal psychosexual development of an individual; d), gender parity on which the "equality formula" creating textbooks is a prerequisite; that involves partnerships and parity opportunities for women and men as subjects of change in social, economic, and political processes; e) preservation of natural expediency of sexually optimal and biologically respective properties of gender belonging personality.

2. The study of socio-psychological factors based on this approach researches the peculiarities of the process of formation of gender-role identity of adolescents and to disclose the conditions necessary for their harmonious development taking into account the person-gender approach.

\section{REFERENCES}

1. Спиноза Б. Избранные произведения [Текст] : Пер. с лат. / Б. Спиноза. - Ростов-на-Дону : Феникс, 1998. - 606 с.

2. Москаленко В.В. Гендерна роль як фактор статеворольової соціалізації // Теоретико-методологічні проблеми генетичної психології: Матер. Міжнар. наук. конф. - К. : Міленіум, 2002. - Т. 1. C. $128-136$.

3. Кізь О.Б. Гендерна соціалізація депривованого юнацтва: дослідження соціально-психологічних детермінант // Зб. матеріалів Всеукр. науково-практ. конференції. - Тернопіль : “Богдан”, 2003. C. $78-85$.

4. Фрейд 3. Введение в психоанализ. Лекции. Пер. с нем. М.: Наука, 1989. - 455 с.

5. Андреева Г.М., Петровская П.А., Богомолова Н.Н. Современная социальная психология на Западе (теоретические направления). - М.: Изд-во МГУ, 1998. - 271 с.

6. Андреева Г. М. Социальная психология. - М. : Наука, 1994. $324 \mathrm{c}$.

7. Психологический словарь / под ред. В.П. Зинченко, Б.Г. Мещерякова ; 2-е изд., перераб. и доп. - М. : Педагогика - Пресс, 1996. -440 c.

8. Эриксон Э. Идентичность: юность и кризис / Пер. с англ. ; общ. ред. и пред. А. В. Толстых. - М. : Прогресс, 1996. - 341 с. 
9. Парыгин Б.Д. Социальная психология: проблемы методологии, истории и теории. - СПб. : ИГУП, 2011. - 592 с.

10. Боришевський М.Й. Психологічні питання статевого виховання учнів // Проблеми викладання курсу етика і психологія сімейного життя. - К. : Наука, 1990. - С. 13-29.

11. Поршнев Б.Ф. Социальная психология и история / Поршнев Б.Ф.; 2-е изд. - М. : Наука, 2009. - 232 с.

12. Фрейд 3. По ту сторону принципа удовольствия. Пер. с нем. / Сост., послесл. и коммент. А.А.Гучнина. М.: Прогресс, Литера, 1992. - 567 c.

13. Фрейд 3. Введение в психоанализ. Лекции. Пер. с нем. М.: Наука, 1989. - 455 с.

14. Хорни К. Женская психология. - СПб. Питер, 2011. - 382 с.

15. Юнг К.Г. Архетип и символ. - М. : Рениссанс, 1991. - 304 с.

16. Эриксон Э. Идентичность: юность и кризис / Пер. с англ. ; общ. ред. и пред. А. В. Толстых. - М. : Прогресс, 1996. - 341 с.

17. Захаров А.И. Психологические особенности восприятия детьми роли родителей // Вопросы психологии. - 1982.- № 1.С. $59-68$.

18. Тельнюк И.В. Индивидуально-дифференцированный подход к организации самостоятельной деятельности девочек и мальчиков 5-6 лет в детском саду: Автореф. дис. ... канд. наук: - СПб., 1999. - 20 с.

19. Васютинський В.О. Особливості статеворольового самовизначення хлопчиків-підлітків із неповної сім'ї: Автореф. дис. ... канд. псих. наук: 19.00.07 - К., 1992. - 19 с.

20.Кон И.С. Психология половых различий // Вопр. псих. 1981. - № 2. - С. 47-57.

21. Петровский А.В. Личность. Деятельность. Коллектив. - М. : Политиздат, 1982. - 255 с.

22. Алешина Ю.Е., Волович А.С. Проблемы усвоения ролей мужчины и женщины // Вопросы психологии. - 1991. - № 7.C. $74-82$.

23. Набиулина Ю.М. Проблема полоролевой идентификации в семейном аспекте // Психология XXI века: Тезисы международной межвузовской научно-практической конференции студентов и аспирантов. - СПб. : Изд-во СПб. ГУ, 2001. - С. 238-239. 
24. Eccles J.S. Gender roles and women's actievement-related decisions // Educational Researcher. 1986. - N15. - Pp. 15-19.

25. Кон И.С. Психология половых различий // Вопр. псих. 1981. - № 2. - С. 47-57.

26. Варга А.Я. Идентификация с родителями и формирование психологического пола // Семья и формирование личности: Сборник научных трудов / Под ред. А.А. Бодалева. - М. : АПН СССР, 1981. C. $10-15$.

27. Алешина Ю.Е., Волович А.С. Проблемы усвоения ролей мужчины и женщины // Вопросы психологии. - 1991. - № 7.C. $74-82$.

28. Баранник О.С. Влияние семьи на формирование тревожности у дошкольников // Ананьевские чтения - 99: Тезисы научнопрактической конференции. - СПб., 1999. - С. 176-177.

29. Чиркова О.Б. Роль детско-родительских отношений в развитии ответственности подростков // Психология XXI века: Тезисы Междунар. межвуз. научно-практ. студенческой конференции. СПб., 2000. - С. 193-195.

30. Светлакова В.П., Токмакова М.А. Влияние родителей на выбор абитуриента // Ананьевские чтения-2001 : Тезисы научнопрактической конференции. - СПб., 2001. - С. 413-414.

\section{Information about the authors: Osmanova A. M.}

Candidate of Psychological Sciences, Associate Professor at the Department of Psychology and Pedagogy of the Educational and Scientific Humanitarian Institute of the V. I. Vernadsky Taurida National University 


\section{CONCLUSIONS}

According to the results of scientific research of socio and psychological problems that are relevant to modern Ukrainian society, it should be noted the diversity of theoretical and empirical approaches and views on their solution should be emphasized.

The phenomenon of intergroup perception in a poly-ethnic space against the backdrop of ongoing changes towards the social individualism of the social and political structure of society, due to the significant differentiation of the population by economic, ethnic, and political characteristics is specified by the social context. The transformation of youth about perceptions of ethical norms, habits, values, and ways of achievement is determined by the communicative image of youth from the social guidance point of view in the process of social perception in the polyethnic and polylinguistic social space of a state.

The singled out social conditions determine the role of a family and school as well as the most influential and long-term approaches in the formation of the gender identity of a child at all stages of its development. The family forms the physical and social life of the child and the most widespread and persistent features of a person that is demonstrated in social activity and which is regulated by the role structure of society are formed in the process of education and upbringing at school.

Gender discrimination is important in the context of contemporary Ukrainian society. The desire of youth to go beyond the limits of discriminatory space and stereotypes is particularly important and needs educational help for young people to determine their growth priorities.

The legal self-determination of persons with low economic status and different levels of psychological attraction to poverty is accomplished in the process of formation of the cognitive, affective, and behavioral components of legal consciousness. Poverty is a factor in violating human rights generally and is an important precondition for deformation of its legal consciousness, social primitiveness of public opinion, and the growth of unlawful attitudes. "Defects" of legal consciousness are caused by real life and socio-economic conditions where legal socialization occurs.

The emergence and distribution of the category of neglected children are connected with the political and economic development of the state, the functioning of its social-legal system, the level of public morality, and the peculiarities of the social protection of the institution of the family. There is a certain system of correctional and rehabilitation systems of state and 
public organizations, centers whose work is aimed at preventing and overcoming the distortions (violations) of the socialization of children and adolescents but this requires optimization and rapid adaptation to changing political, economic, and social contexts.

The usage of correctional, developmental, and informational methods to optimize the process of legal self-determination of representatives of social groups of the poor and the development of a person's resource attitude to different conditions and circumstances, situations of uncertainty and the ability to efficient coping strategies are important in solving the identified problems.

The recreational approach that promotes the implementation of social work is the synthesis of various theories and practices. This approach is aimed at the restoration of a person who needs social help. Polyfunctionality is the ultimate goal of building an integrative model of social work. This is revealed in attracting creative potentials through the functioning of numerous functions and especially recreational function when the personal efforts of a client are updated with the usage of individual and social resources to influence the situation and maintain a balance between the client and the living environment.

The identified issues point to the need for a state family policy in Ukraine which is aimed at strengthening the social institution of the family. One of the directions of its implementation is social work with the family which takes into account the features of the family as a social system, the primary staff, a special small social group, and special work with difficult families who have more serious problems. A state program for the development of a creative environment that includes all areas from a developing space and a system of education including educational psychological and pedagogical activities with youth and families should be formed.

Applied aspects of solving some topical problems are presented as a Program of socio-psychological support of parenthood. The program provides the opportunity to obtain the necessary information about the peculiarities of the upbringing of the child, the existing problems about the child, as well as obtain their own experience of their solution. The result of participation in the program should be the construction of their parenting position, changing the attitude towards the child - from awareness of themselves and the child as a unified system, to recognition of the child as an individual, who has his own subjectivity, as well as the construction of a system of communication with her as an equal partner on a trust basis. 
NOTES 


\section{NOTES}


NOTES 
Publishing house "Liha-Pres"

9 Kastelivka str., Lviv, 79012, Ukraine 44 Lubicka str., Toruń, 87-100, Poland

Printed by the publishing house "Liha-Pres"

Passed for printing: August 30, 2019.

A run of 150 copies. 